\title{
GROUND-WATER RESOURCES AND WATER-SUPPLY ALTERNATIVES IN THE WAWONA AREA OF YOSEMITE NATIONAL PARK, CALIFORNIA
}

By James W. Borchers

U.S. GEOLOGICAL SURVEY

Water-Resources Investigations Report 95-4229

Prepared in cooperation with the

NATIONAL PARK SERVICE

온 


\section{U.S. DEPARTMENT OF THE INTERIOR \\ BRUCE BABBIT, Secretary}

\section{U.S. GEOLOGICAL SURVEY \\ GORDON P. EATON, Director}

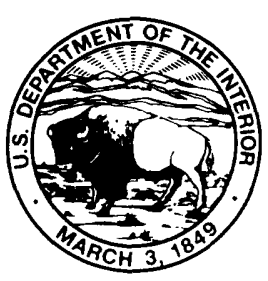

Any use of trade, product, or firm names in this publication is for descriptive purposes only and does not imply endorsement by the U.S. Government.

For sale by the

U.S. Geological Survey

Earth Science Information Center

Open-File Reports Section

Box 25286, MS 517

Denver Federal Center

Denver, CO 80225

For additional information write to:

District Chief

U.S. Geological Survey

Federal Building, Room W-2233

2800 Cottage Way

Sacramento, CA 95825 


\section{CONTENTS}

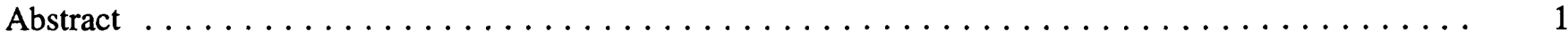

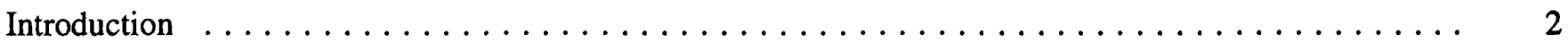

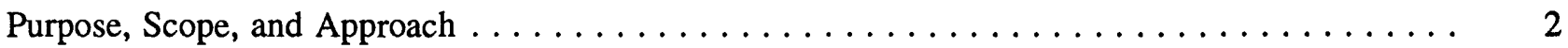

Description of Study Area $\ldots \ldots \ldots \ldots \ldots \ldots \ldots \ldots \ldots \ldots \ldots \ldots \ldots \ldots \ldots$

Physical Setting $\ldots \ldots \ldots \ldots \ldots \ldots \ldots \ldots \ldots \ldots \ldots \ldots \ldots \ldots \ldots \ldots$

Geologic and Hydrologic Setting $\ldots \ldots \ldots \ldots \ldots \ldots \ldots \ldots \ldots \ldots \ldots \ldots$

Climate ................................ 4

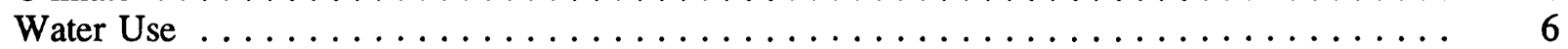

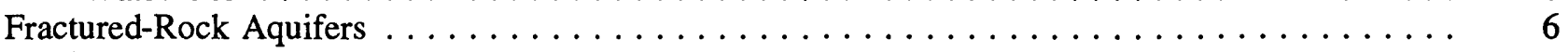

Previous Studies $\ldots \ldots \ldots \ldots \ldots \ldots \ldots \ldots \ldots \ldots \ldots \ldots \ldots \ldots \ldots$

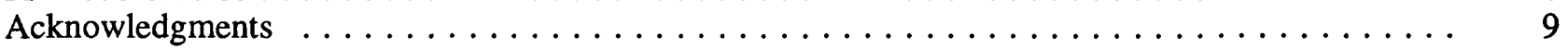

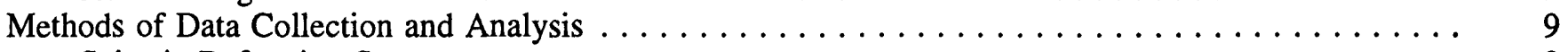

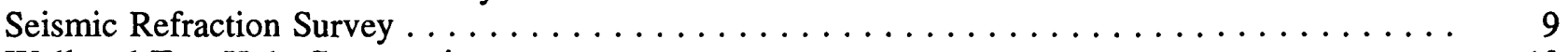

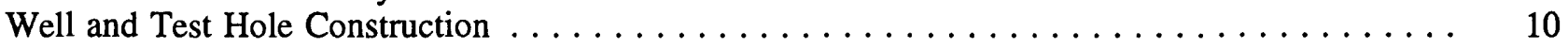

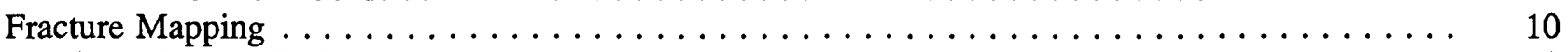

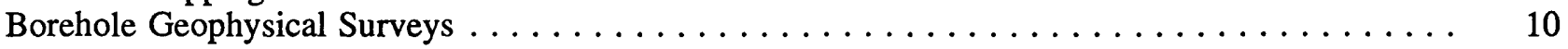

In Situ Stress Measurement . . . . . . . . . . . . . . . . . . . . . . . . . . 12

Water Sampling and Analysis $\ldots \ldots \ldots \ldots \ldots \ldots \ldots \ldots \ldots \ldots \ldots \ldots \ldots \ldots \ldots \ldots$

Stream Gain-and-Loss Studies . . . . . . . . . . . . . . . . . . . . . . . . . 14

Ground Water in the South Fork Merced River Valley at Wawona . . . . . . . . . . . . . . . . 15

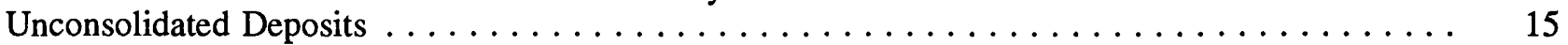

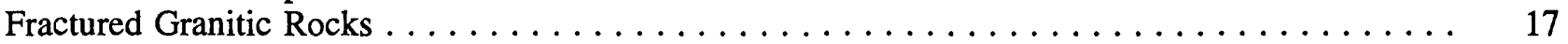

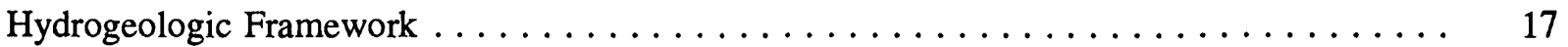

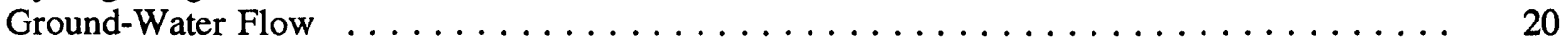

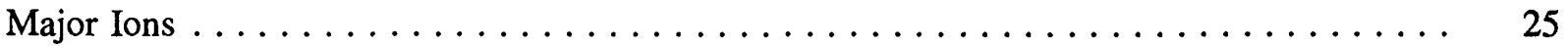

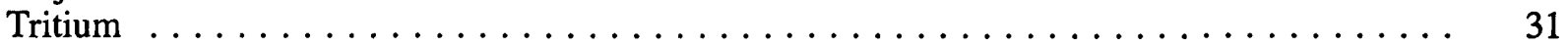

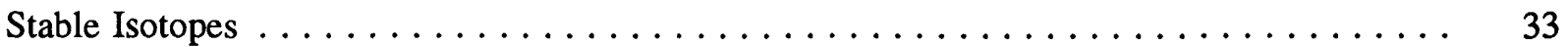

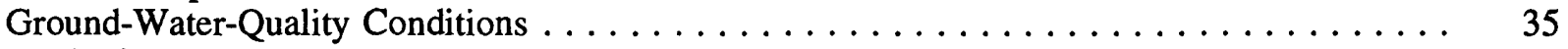

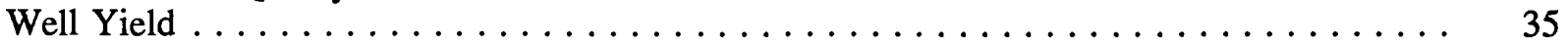

Relation to Flow in the South Fork Merced River $\ldots \ldots \ldots \ldots \ldots \ldots \ldots \ldots \ldots$

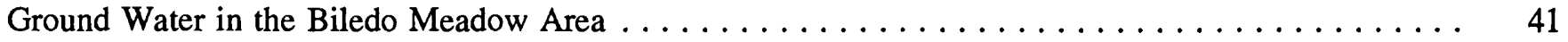

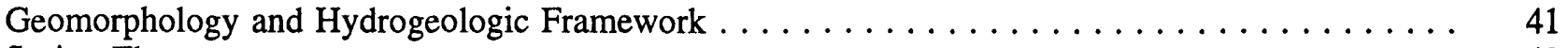

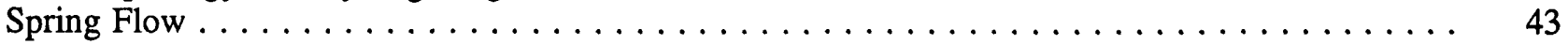

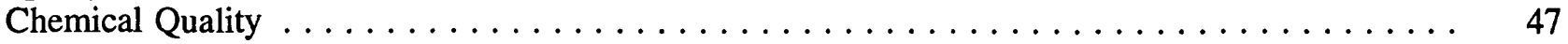

Relation to Flow in Rainier Creek $\ldots \ldots \ldots \ldots \ldots \ldots \ldots \ldots \ldots \ldots \ldots \ldots \ldots$

Water-Supply Alternatives for Wawona $\ldots \ldots \ldots \ldots \ldots \ldots \ldots \ldots \ldots \ldots \ldots \ldots \ldots \ldots \ldots \ldots$

South Fork Merced River . . . . . . . . . . . . . . . . . . . . . . . 49

Ground Water in the South Fork Merced River Valley $\ldots \ldots \ldots \ldots \ldots \ldots \ldots \ldots \ldots \ldots$

Biledo Spring $\ldots \ldots \ldots \ldots \ldots \ldots \ldots \ldots \ldots \ldots \ldots \ldots \ldots \ldots \ldots \ldots \ldots \ldots \ldots \ldots$

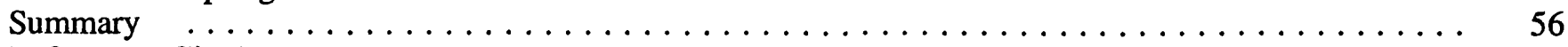

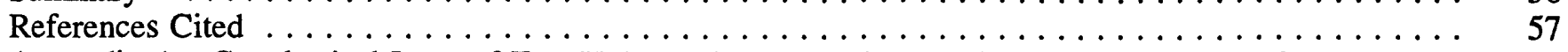

Appendix A: Geophysical Logs of Test Holes and Wells and Acoustic Televiewer Logs of Test Holes 61

Appendix B: Hydrographs of Water Levels in Selected Observation Wells . . . . . . . . . . . 71

Appendix C: Method Used to Estimate Discharge of Biledo Spring . . . . . . . . . . . . . 77 


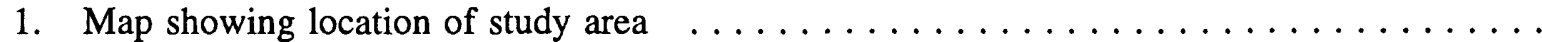

2. Map showing geology of the Wawona area, Yosemite National Park . . . . . . . . . . . .

3. Graph showing monthly water use at Wawona, $1989-91 \ldots \ldots \ldots \ldots \ldots \ldots \ldots \ldots \ldots$

4. Map showing location of wells, test holes, and stream water-quality site in the

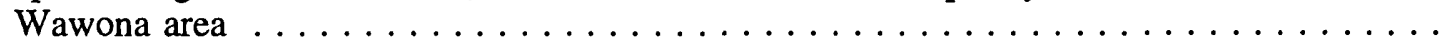

5. Diagram showing determination of fracture orientation from acoustic televiewer log of

test hole 2 in the Wawona area . . . . . . . . . . . . . . . . . . . .

6. Seismic cross section, Wawona meadow . . . . . . . . . . . . . . .

7-10. Diagrams showing:

7. Orientation and relative magnitude of vertical and horizontal stresses in rocks beneath the South Fork Merced River valley at Wawona . . . . . . . . . . . .

8. Strike direction for 227 fractures as determined by acoustic televiewer logs of test holes 1 and 2 and wells $\mathrm{R} 1$ and 36M1 in the Wawona area .........

9. Strike direction for 25 permeable fractures as determined by acoustic televiewer logs of test holes 1 and 2 and wells R1 and 36M1 in the Wawona area . . . . .

10. Conceptual model of the fractured-rock aquifer beneath the valley floor at Wawona showing permeable fractures $\ldots \ldots \ldots \ldots \ldots \ldots$

11. Map showing hydraulic head in shallow wells and generalized direction of ground-water flow in the Wawona area, autumn 1992

12. Map showing hydraulic head in shallow wells and generalized direction of ground-water flow in the Wawona area, winter/spring 1993

13. Trilinear diagram showing chemical composition of water samples from wells, springs, and streams in the Wawona area . . . . . . . . . . . . . . . . . . . .

14-19. Graphs showing:

14. Bromide to chloride ratio as a function of chloride concentration in ground water and mean bromide to chloride ratio for two fluid-inclusion samples from granitic quartz in the Wawona area . . . . . . . . . . . . . . . .

15. Tritium concentrations expected in ground water in the Wawona area that originated as precipitation between 1953 and $1983 \ldots \ldots \ldots \ldots \ldots \ldots$

16. Relation between deuterium and oxygen- 18 for all ground-water samples from the

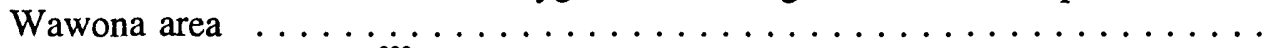

17. Distribution of dissolved ${ }^{222}$ radon in ground-water samples from wells in the

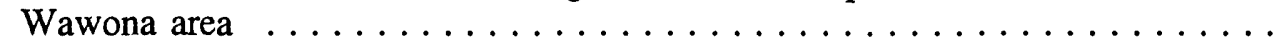

18. Comparison of drillers' estimated yield with short-term pumping-test yields for wells in the Wawona area . . . . . . . . . . . . . . . . . . . .

19. Relation between short-term well yield and well depth for wells in the

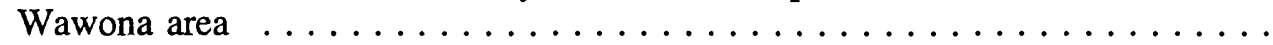

20. Map showing location of streamflow reporting sites on the South Fork Merced River, wells in the losing reach of the river, and section $B-B^{\prime} \ldots \ldots \ldots \ldots \ldots \ldots$

21. Graph showing discharge of the South Fork Merced River at streamflow reporting sites during gain-and-loss studies between August 1, 1991, and October 8, $1992 \ldots \ldots \ldots \ldots$

22. Graph showing cumulative gains or losses in flow of the South Fork Merced River at streamflow reporting sites between August 1, 1991, and October 8, $1992 \ldots \ldots \ldots \ldots$

23. Cross section showing relation between hydraulic head in shallow and deep wells in the losing reach of the South Fork Merced River during the gain-and-loss study on

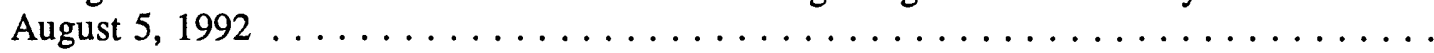

24. Diagram showing conceptual model of ground-water flow in the Biledo Meadow area,

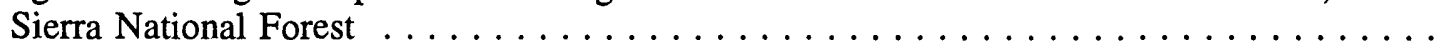

25. Map showing location of springs and streamflow reporting sites in the Biledo Meadow area

26. Photograph showing excavation for the lower cistern at Biledo Spring, July 26, 1931 . . . .

27. Photograph showing excavation for the upper cistern at Biledo Spring, July 26, $1931 \ldots \ldots$ 
28-35. Graphs showing:

28. Discharge of Biledo Spring and Biledo Meadow springs 1 and 2, Sierra National Forest, and precipitation at the south entrance station at Yosemite National

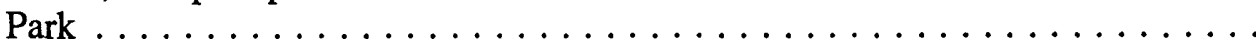

29. Specific conductance and discharge at streamflow reporting sites during the gain-and-loss studies on Rainier Creek . . . . . . . . . . . . . 48

30. Mean daily discharge of the South Fork Merced River at Wawona, October 1, 1958, to September 30,1968 . . . . . . . . . . . . . . .

31. Streamflow frequency for the South Fork Merced River at Wawona for the period of continuous streamflow measurement, October 1,1958 , to

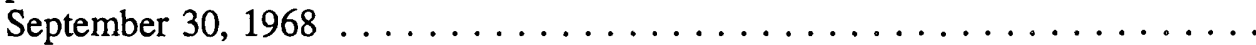

32. Streamflow frequency for the South Fork Merced River at Wawona for the months of August, September, and October between October 1, 1958, and

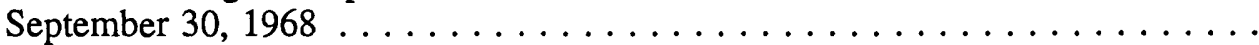

33. Annual departure from the 1961-90 mean discharge for the Merced River at Pohono Bridge ..........................

34. Variation of well discharge and specific conductance during and after the flow

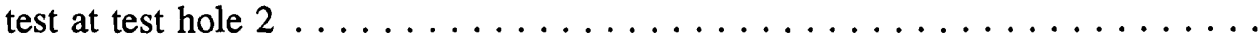

35. Mean daily discharge diverted from Big Creek by the Madera Irrigation

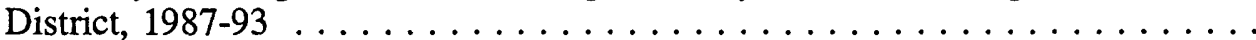

\section{TABLES}

1. Water-level altitudes and changes in water levels for shallow wells and wells producing water from shallow fractures in Wawona, Yosemite National Park, autumn 1992 and

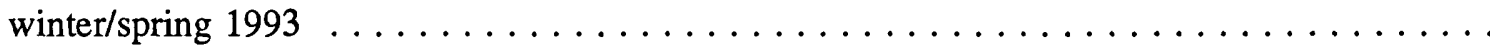

2. Selected chemical data for ground water from wells at Wawona, Biledo Spring, and Biledo Meadow spring 1 and from stream sampling sites in the Wawona area of Yosemite National Park and the Sierra National Forest, summer 1991 through autumn 1993

3. Isotopic composition of ground-water samples from wells, test holes, and springs in the Wawona area of Yosemite National Park and the Sierra National Forest . . . . . . . . . . .

4. Streamflow and specific conductance data used to calculate discharge and specific conductance of unmeasured inflow to the South Fork Merced River between streamflow reporting sites

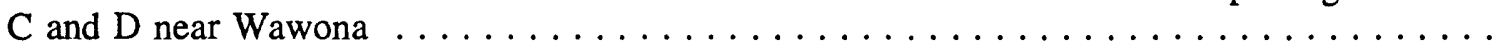

5. Basin yields for Rainier Creek, Long Meadow Creek, and White Chief Branch, Sierra National Forest, and for the South Fork Merced River at Wawona, Yosemite National Park . . . . . . .

6. Dissolved ${ }^{222}$ radon in ground water in the Wawona area, Yosemite National Park and Sierra National Forest, $1992 \ldots \ldots \ldots \ldots \ldots \ldots \ldots \ldots \ldots \ldots$

7. Total ground-water discharge from springs and seeps in the Biledo Meadow area to Rainier Creek . . . . . . . . . . . . . . . . . . . . . . . . 


\section{CONVERSION FACTORS, VERTICAL DATUM, WATER-QUALTTY INFORMATION, AND WELL- AND SPRING-NUMBERING SYSTEM}

\section{Conversion Factors}

\begin{tabular}{rll}
\hline Multiply & By & To obtain \\
foot $(\mathrm{ft})$ & 0.3048 & meter \\
foot per foot $(\mathrm{ft} / \mathrm{ft})$ & 1 & meter per meter \\
foot per second $(\mathrm{ft} / \mathrm{s})$ & 0.3048 & meter per second \\
inch (in.) & 25.4 & millimeter \\
mile $(\mathrm{mi})$ & 1.609 & kilometer \\
square $\mathrm{mile}^{2}\left(\mathrm{mi}^{2}\right)$ & 2.590 & square kilometer \\
cubic foot per second $\left(\mathrm{ft}^{3} / \mathrm{s}\right)$ & 0.0283 & cubic meter per second \\
cubic foot per year $\left(\mathrm{ft}^{3} / \mathrm{yr}\right)$ & 0.0283 & cubic meter per year \\
gallon per day $(\mathrm{gal} / \mathrm{d})$ & 0.00375 & cubic meter per day \\
gallon per minute $(\mathrm{gal} / \mathrm{min})$ & 227 & liter per second \\
\end{tabular}

Temperature is given in degrees Celsius $\left({ }^{\circ} \mathrm{C}\right)$, unless otherwise noted, which can be converted to degrees Fahrenheit $\left({ }^{\circ} \mathrm{F}\right)$ by the following equation:

$$
{ }^{\circ} \mathrm{F}=1.8\left({ }^{\circ} \mathrm{C}\right)+32 .
$$

\section{Vertical Datum}

Sea level: In this report, "sea level" refers to the National Geodetic Vertical Datum of 1929-a geodetic datum derived from a general adjustment of the first-order level nets of the United States and Canada, formerly called Sea Level Datum of 1929.

\section{Water-Quality Information}

Chemical concentration is given in milligrams per liter $(\mathrm{mg} / \mathrm{L})$ or micrograms per liter $(\mu \mathrm{g} / \mathrm{L})$. Milligrams per liter is a unit expressing the solute per unit volume (liter) of water. One thousand micrograms per liter is equivalent to 1 milligram per liter. For dissolved-solids concentrations less than $7,000 \mathrm{mg} / \mathrm{L}$, the numerical value in milligrams per liter is about the same as for concentrations in parts per million (ppm), and the numerical value in micrograms per liter is about the same as for concentrations in parts per billion (ppb). Specific conductance is given in microsiemens per centimeter at $25^{\circ} \mathrm{C}(\mu \mathrm{S} / \mathrm{cm})$. Microsiemens per centimeter is numerically equal to micromhos per centimeter. The concentration of dissolved ${ }^{222}$ radon is expressed in picoCuries per liter $(\mathrm{pC} / \mathrm{L}) ; 1 \mathrm{pC}$ is equivalent to 2.2 disintegrations per minute. The concentration of dissolved tritium is expressed in tritium units (TU); 1 TU is 1 tritium atom per $10^{18}$ hydrogen atoms or is equivalent to 7.1 disintegrations per minute per liter. Stable isotopes are reported relative to Vienna Standard Mean Oceanic Water (V-SMOW) in permil notation.

The saturation index ( $\mathrm{SI}=\mathrm{IAP} / \mathrm{K}_{\mathrm{sp}}$ ) is the ratio of the activity product of ions (IAP) in solution and the solubility equilibrium constant $\left(\mathrm{K}_{\mathrm{sp}}\right)$ of a mineral. It is a measure of a mineral's tendency to dissolve or precipitate. A positive value indicates that the water is supersaturated with respect to the mineral considered and that the mineral would tend to precipitate. A negative value indicates that the water is undersaturated with respect to the mineral considered and that mineral, if present, would tend to dissolve. 


\section{Well and Spring Numbering System}

Wells and springs are identified and numbered according to their location in the rectangular system for the subdivision of public lands. Identification consists of the township number, north or south of the Mount Diablo base line; the range number, east or west of the Mount Diablo meridian; and the section number. Each section is divided into sixteen 40-acre tracts lettered consecutively (except $\mathrm{I}$ and $\mathrm{O}$ ), beginning with " $\mathrm{A}$ " in the northeast corner of the section and progressing in a sinusoidal manner to " $R$ " in the southeast corner. Within the 40 -acre tract, wells are sequentially numbered in the order they are inventoried. The letter " $S$ " inserted before the sequence number indicates a spring. The final letter refers to the base line and meridian. In California, there are three base lines and meridians: Humboldt $(\mathrm{H})$, Mount Diablo (M), and San Bernardino (S). All wells in the study area are referenced to the Mount Diablo base line and meridian $(M)$. Well numbers consist of 15 characters and follow the format 004S021E35R1. In this report, well numbers are abbreviated and written 4S/21E-35R1. Wells in the same township and range are referred to only by their section designation, 35R1. Wells in the same section are referred to only by their letter and number designation, $R 1$. The following diagram shows how the number for well $4 \mathrm{~S} / 21 \mathrm{E}-35 \mathrm{R} 1$ is derived.

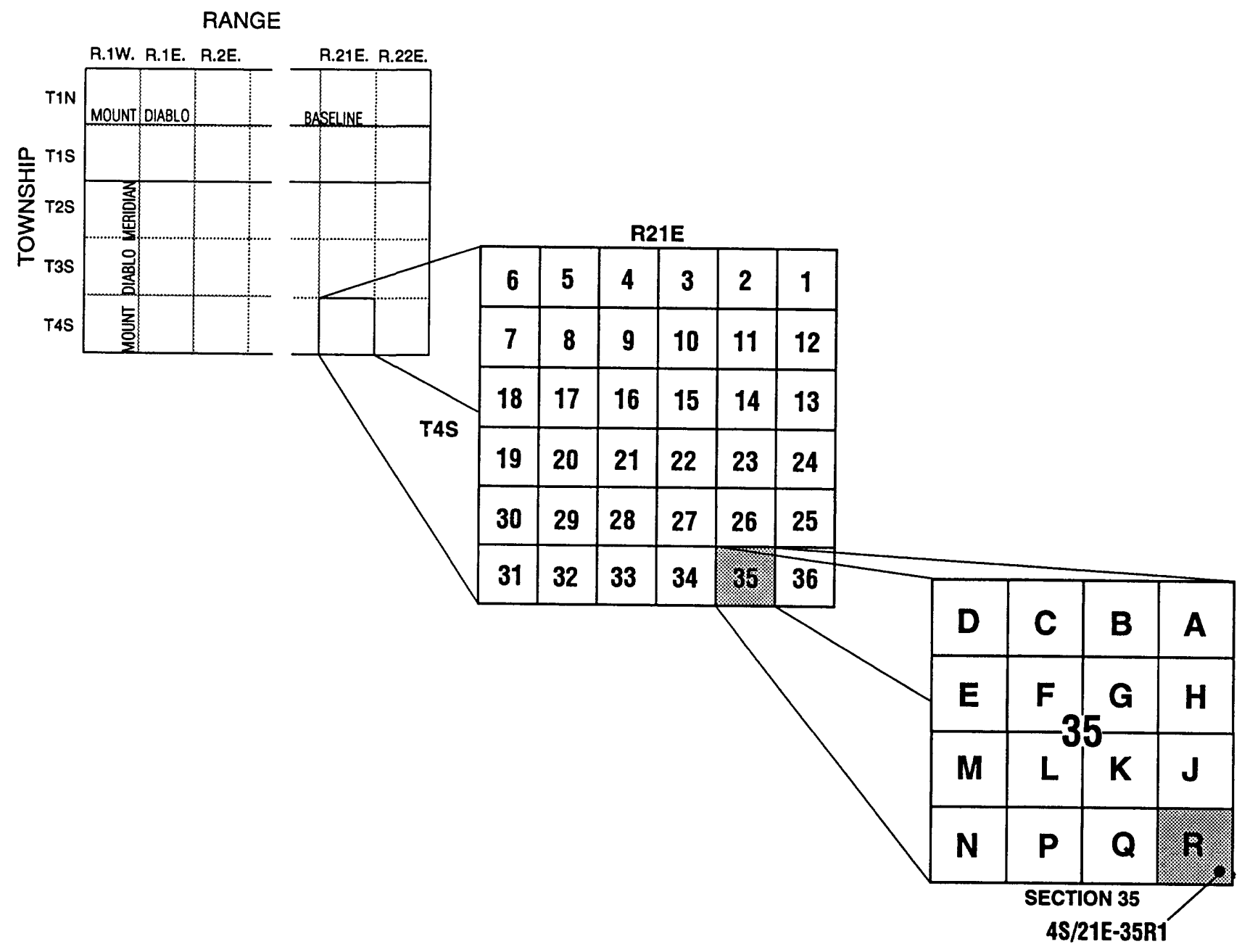




\title{
Ground-Water Resources and Water-Supply Alternatives in the Wawona Area of Yosemite National Park, California
}

\author{
By James W. Borchers
}

Abstract

Planning efforts to implement the 1980 General Management Plan, which recommends relocating park administrative facilities and employee housing from Yosemite Valley in Yosemite National Park, California, have focused on the availability of water at potential relocation sites within the park. Ground-water resources and water-supply alternatives in the Wawona area, one of several potential relocation sites, were evaluated between June 1991 and October 1993.

Ground water flowing from Biledo Spring near the headwaters of Rainier Creek, about 5 miles southeast of Wawona, is probably the most reliable source of good quality ground water for Wawona. A dilute calcium bicarbonate ground water flows from the spring at about 250 gallons per minute. No Giardia was detected in a water sample collected from Biledo Spring in July 1992. The concentration of dissolved ${ }^{222}$ radon at Biledo Spring was 420 picoCuries per liter, exceeding the primary drinking-water standard of 300 picoCuries per liter proposed by the U.S. Environmental Protection Agency. This concentration, however, was considerably lower than the concentrations of dissolved ${ }^{222}$ radon measured in ground water at Wawona. The median value for 15 wells sampled at Wawona was 4,500 picoCuries per liter.

Water-quality samples from 45 wells indicate that ground water in the South Fork Merced River valley at Wawona is segregated vertically. Shallow wells produce a dilute calcium sodium bicarbonate water that results from chemical dissolution of minerals as water flows through fractured granitic rock from hillside recharge areas toward the valley floor. Tritium concentrations indicate that ground water in the shallow wells originated as precipitation after the 1960's when testing of atmospheric nuclear devices stopped. Ground water from the deep flowing wells in the valley floor is older sodium calcium chloride water. This older water probably originated either as precipitation during a climatically cooler period or as precipitation from altitudes between 1,400 and 3,700 feet higher than precipitation that recharged the local shallow ground-water-flow system. Chloride and associated cations in the deep ground-water-flow system may result from upward leakage of saline ground water or from leaching of saline fluid inclusions in the granitic rocks.

Water-level and pressure-gage measurements for 38 wells in the South Fork Merced River valley also indicate that the ground water in the valley is segregated vertically. Hydraulic head in deep fractures is as much as 160 feet above the valley floor. Vertical hydraulic gradients between the shallow and deep systems are as high as 4.5 feet per foot in one of two test holes drilled for this study. Measurements of in situ stress in the two test holes indicate that the vertical segregation of ground water may be related to pressures in the earth that squeeze horizontal fractures closed at depth. Fractures within a few hundred feet of land surface are poorly connected to fractures deeper beneath the valley.

About 100 privately owned wells currently are in use at Wawona; but, the ground-waterflow system may not be an adequate source of good quality ground water for relocated park facilities. Yields from existing wells are low (median 4-5 gallons per minute) and traditional methods for locating high-yielding wells in fractured rocks have not been successful in this area. Concentrations of dissolved ${ }^{222}$ radon (median 4,500 picoCuries per liter) are high, and the development of deep ground water could cause deeper saline water to migrate upward into producing wells.

The South Fork Merced River, the primary source of water supply for Wawona, does not meet current demands during late summer and 
autumn. Data collected between 1958 and 1968 indicate that 25 percent of the time discharge of the South Fork River at Wawona during the dry season (August through October) was less than 2 cubic feet per second-the discharge rate at which the National Park Service is restricted from withdrawing water from the river. The river, however, could be relied on for additional water supply if facilities were constructed to divert and store water during periods of high flow for use later in the year.

\section{INTRODUCTION}

A recommendation in the 1980 General Management Plan for Yosemite National Park, California, is to relocate park administrative facilities and concessionaire and employee housing from Yosemite Valley to other locations within the park. Because of concerns about the availability of adequate water supplies at proposed relocation sites, only some relocation has occurred. One of the proposed relocation sites is the Wawona area, near the south entrance to Yosemite National Park.

The primary source of water in Wawona is the South Fork Merced River; however, the river does not adequately meet water-supply demands during late summer and autumn. Because of limited water supplies, most private residences in Wawona have not been connected to the National Park Service water system. Current diversions from the South Fork Merced River to the park's water system reduce flow of the river and have the potential to adversely affect downstream aquatic environments during August, September, and October. Low streamflow, exacerbated during the recent drought (1987-92), has resulted in adoption of emergency water-conservation measures on several occasions.

This study was done in cooperation with the National Park Service to help determine the feasibility of relocating park facilities from Yosemite Valley to Wawona and of expanding the National Park Service water system. Information from this study will provide planners and managers of Yosemite National Park with reliable information about alternative sources of water for Wawona.

\section{Purpose, Scope, and Approach}

This report presents the results of a hydrologic investigation of water resources in the Wawona area of Yosemite National Park, California (fig. 1), from June 1991 through October 1993. The results of this study will provide planners and managers of the National Park Service with information necessary to determine the feasibility of relocating park facilities to Wawona and to develop additional water supplies for existing facilities at Wawona.

Originally, this study was designed as a reconnaissance-level inventory of potential watersupply sources. Collection of data from existing wells in Wawona was excluded from the original study design because it was thought that all wells in Wawona had been destroyed (filled with grout) to comply with county regulations that specify setback distances between water-supply wells and the National Park Service sewer system constructed in 1983. However, results of a field reconnaissance in July 1991 indicated that many of the private wells had not been destroyed and that new wells had been drilled. As a result of the reconnaissance, the scope of the study was expanded to include data collection from existing wells. During this study, 85 of approximately 100 privately owned wells in Wawona were located and inventoried. Data were collected from some of the 85 wells.

The primary focus of the report is the groundwater-flow system in the South Fork Merced River valley at Wawona. The hydrologic character of unconsolidated deposits in the valley was evaluated by geologic reconnaissance, seismic refraction studies, and water-level measurements in a few shallow wells dug in thin alluvium and glacial till. The hydrogeologic framework of the fractured-rock aquifer supplying water to most wells at Wawona was studied by mapping fracture traces on aerial photographs and fractures at outcrops and by using borehole geophysical methods to determine the orientation of water-bearing fractures in wells. Anisotropy of hydraulic properties of the aquifer was studied by comparing the orientation of the permeable fractures in two test holes drilled in the valley floor at Wawona to the orientation of the earth's stress field measured in the test holes. Shortterm well yield was evaluated by single-well pumping tests on 42 wells. The direction of groundwater flow and seasonal water-level fluctuations were determined by intermittent measurement of water levels in 38 wells.

This report also describes hydrologic conditions near Biledo Meadow at the headwaters of Rainier Creek about 5 mi southeast of Wawona, just outside of Yosemite National Park in the Sierra National Forest (fig. 1). Biledo Spring currently supplies water to facilities at the south entrance station of Yosemite National Park. The station is about 2.5 mi southeast of Wawona. For this report, Biledo Spring is considered to be in the Wawona area and could represent an additional source of water for Wawona.

Streamflow characteristics of the South Fork Merced River at Wawona were examined to evaluate the river as a source of additional water for Wawona. 


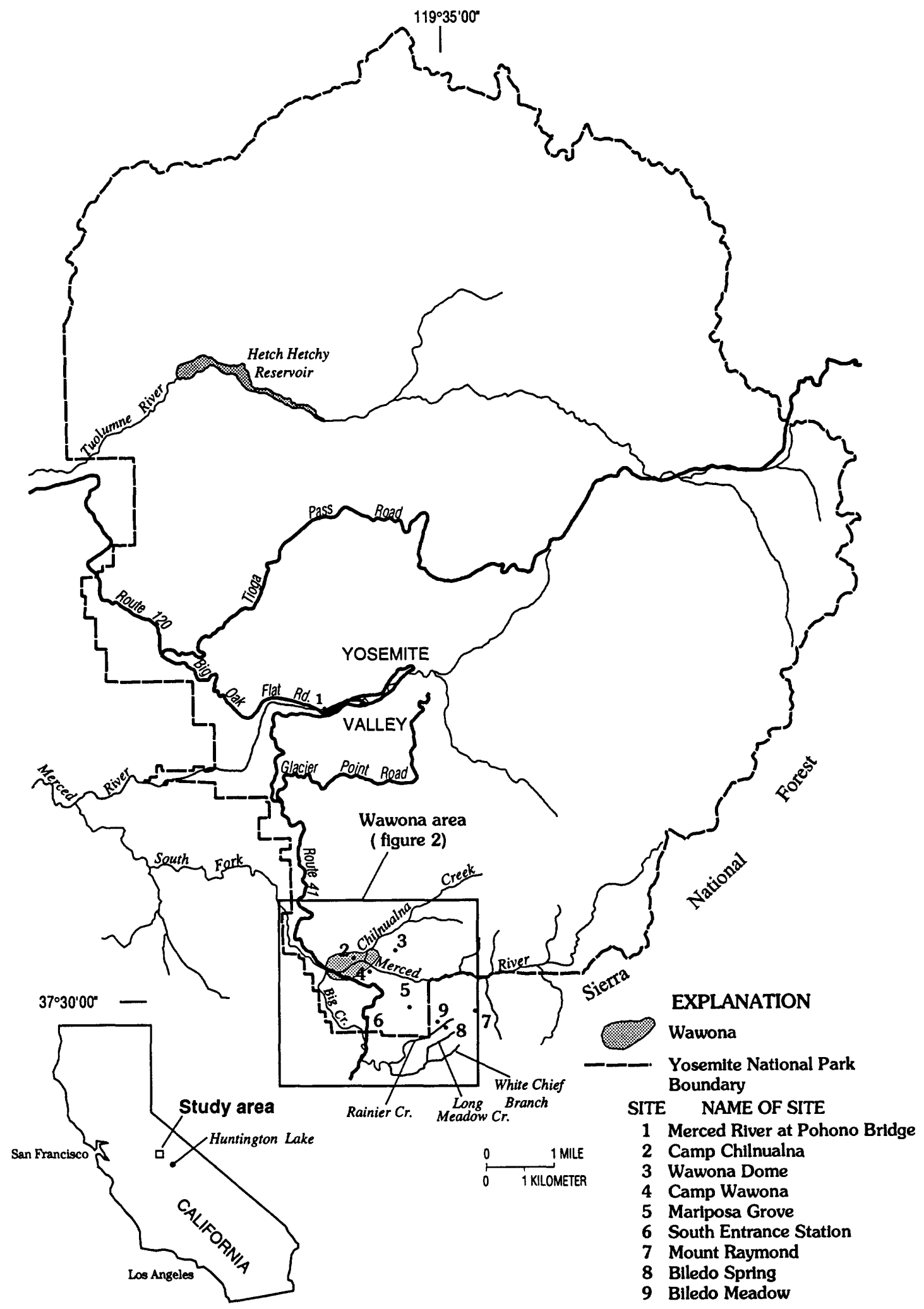

Figure 1. Location of study area. 
The chemical composition of ground water in the Wawona area was evaluated by analyzing water samples from 45 wells and 2 springs for major elements, from 26 wells and 2 springs for trace elements (Johnson and others, 1991), from 36 wells and 2 springs for stable isotopes of oxygen and hydrogen and for tritium, and from 15 wells and 3 springs to determine dissolved ${ }^{222}$ radon concentrations. A sample was collected from Biledo Spring to determine if Giardia, a parasitic organism often found in surface water of the Sierra Nevada, was present. The chemical composition of the South Fork Merced River and Rainier Creek was evaluated by collecting a water sample from each stream for analysis of major and trace elements.

Interaction between ground and surface water during the dry season was studied by stream gainand-loss studies on the South Fork Merced River. Gain-and-loss studies also were done to determine the influence of springs and other ground-water discharge on the flow of Rainier Creek.

\section{Description of Study Area}

\section{Physical Setting}

Wawona is near the southern boundary of Yosemite National Park, which is in the central western Sierra Nevada about 150 mi east of San Francisco (fig. 1). It lies in the South Fork Merced River valley at an altitude of about $4,500 \mathrm{ft}$ above sea level; adjacent mountains reach altitudes of more than $9,000 \mathrm{ft}$ above sea level. Wawona is about a 45-minute drive from the popular attractions in Yosemite Valley. Wawona consists of 265 private residences, 107 residences owned by the National Park Service, a hotel with 104 rooms, a restaurant, a campground with 98 camp sites, a golf course, 2 stores, and a children's camp.

Biledo Meadow, just outside of Yosemite National Park, is 5.5 mi southeast of Wawona on the southwestern side of Mount Raymond at the headwaters of Rainier Creek in the Sierra National Forest (fig. 1). It is at an altitude of about $7,400 \mathrm{ft}$ above sea level and, because of the winter snowpack, is accessible only between June and November.

\section{Geologic and Hydrologic Setting}

The South Fork Merced River valley at Wawona is carved into plutonic rocks composed of El Capitan Granite and Tonalite of the Gateway of Cretaceous age (fig. 2). The El Capitan Granite, a coarse-grained biotite granite and biotite granodiorite about 102 million years old, underlies the eastern part of the Wawona area, which includes Wawona Dome (Huber and others, 1989). The Tonalite of the Gateway, a medium-grained biotite-hornblende tonalite that varies to granodiorite and quartz diorite about 114 million years old underlies the western part of the Wawona area and the Wawona meadow (Huber and others, 1989). Since the granitic rocks formed, uplift and erosion have combined to remove at least $2.3 \mathrm{mi}$ (Bateman, 1992) and perhaps as much as $10 \mathrm{mi}$ of overlying material (Bateman and Wahrhaftig, 1966). Thermal and tectonic stresses associated with uplift, erosion, and other sources of stress have created joints, fractures, and faults in the granitic rocks.

Deposits from three glacial epochs are found upstream of Wawona. The low ridge that separates the South Fork Merced River valley from the Wawona meadow is capped with Pre-Tahoe Till (Qpt), the oldest of these deposits (fig. 2). Alluvial deposits underlie the Wawona meadow and crop out in the channel of the South Fork Merced River.

The South Fork Merced River flows westward over granitic bedrock to Wawona and then flows northwest to an area underlain by early Paleozoic metasedimentary rocks (fig. 2). Upstream from Wawona, tributaries enter the steep-walled canyon of the South Fork Merced River from the north and south. The drainage area of the South Fork Merced River, just upstream of Big Creek, is about $100 \mathrm{mi}^{2}$.

The Biledo Meadow area near the headwaters of Rainier Creek is underlain by the Tahoe Till. The Tahoe Till covers Jurassic metasedimentary and Cretaceous metavolcanic rocks and the Tonalite of the Gateway. Bedrock in the area is intensely fractured (William McCaffrey, U.S. Forest Service, written commun., 1991). Offset geologic contacts on each side of the Tahoe Till underlying Biledo Meadow may indicate displacement on faults hidden by the till (fig. 2).

Rainier Creek drains the southwest slope of Mount Raymond and flows into Big Creek, which joins the South Fork Merced River about $0.25 \mathrm{mi}$ downstream from Wawona (fig. 2). The headwater locations of Rainier Creek and adjacent streams probably are controlled by fractures or faults in the underlying granitic and metamorphic rock (fig. 2). Stream locations often are controlled by fractures in the plutonic rocks of the Sierra Nevada (Huber, 1987). The drainage area of Rainier Creek upstream of the southwestern limit of the Tahoe Till is $1.4 \mathrm{mi}^{2}$.

\section{Climate}

Precipitation in the Sierra Nevada is highly variable in amount and timing. More than 80 percent of the precipitation in Yosemite National 


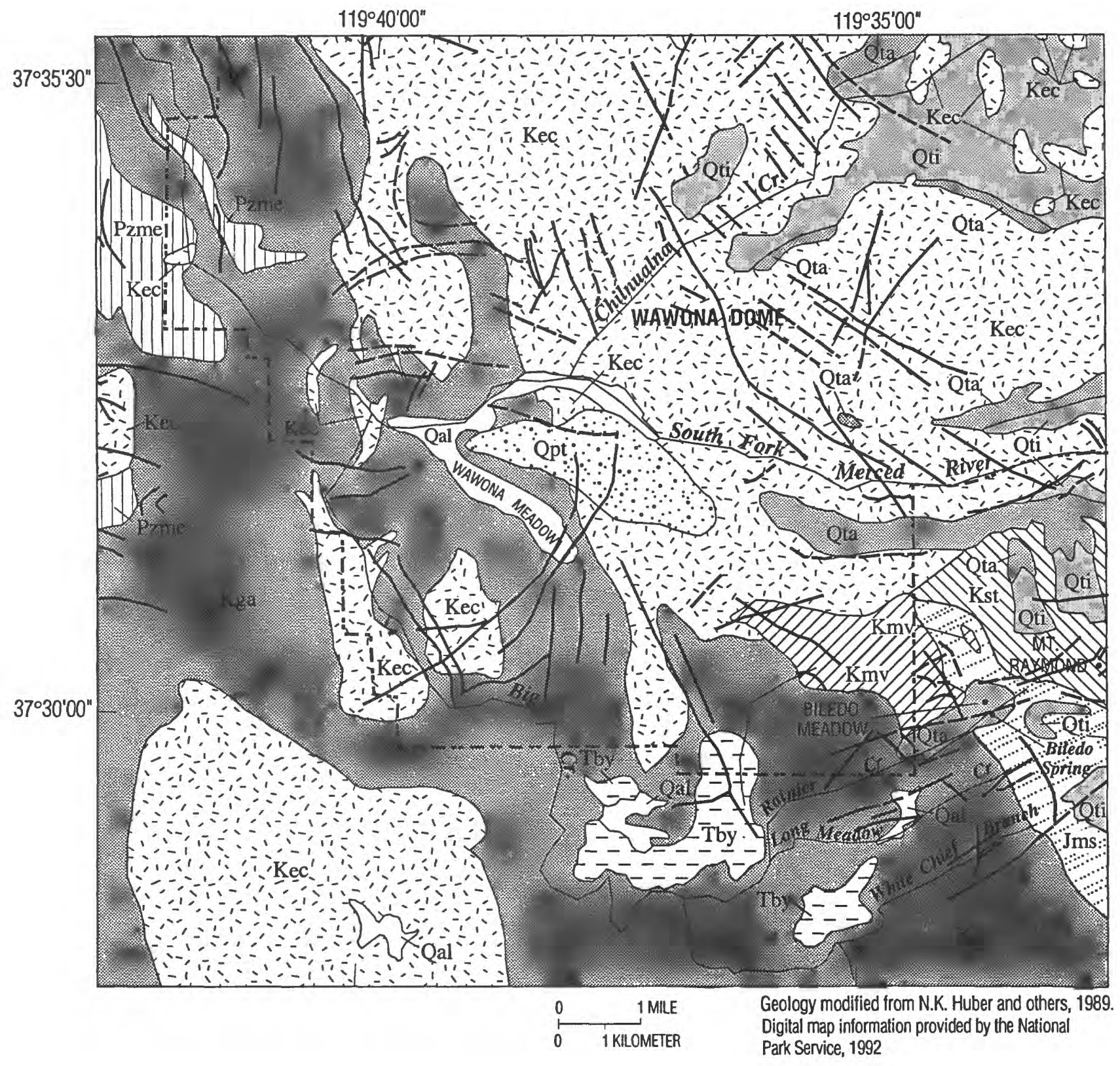

\section{EXPLANATION}

Qal Alluvium (Holocene)

Qti Tioga Till (Pleistocene)

1. Tahoe Till (Pleistocene)

Qpt: Pre-Tahoe Till (Pleistocene)

[T믈

Ksty Granite porphyry of Star Lakes (Cretaceous)
Kec El Capitan Granite and similar rocks (includes Granodiorite of Ostrander Lake (Kol), Granodiorite of Illioutte Creek (Kic), Quartz diorite (Kid), Granite porphyry of Shellenbarger Lake (Ksl), Taft Granite and similar rocks (Kt) (Cretaceous)

Tonalite of the Gateway and similar rocks (Cretaceous)

Kmy Metavolcanic rocks, undivided (Cretaceous)

Metasedimentary rocks, undivided (Jurassic)

PZme Metasedimentary rocks, undivided (Paleozoic)

_ Fracture trace mapped from aerial photographs. Dashed where approximately located

-.. - Yosemite National Park Boundary

Figure 2. Geology of the Wawona area, Yosemite National Park, California. 
Park falls between November and March (Daniel Cayan, Scripps Institute of Oceanography, written commun., 1994). At Wawona, precipitation occurs either as rain or snow, which melts quickly and flows into streams. At higher altitudes of the South Fork Merced River basin, precipitation usually occurs as snow, which melts more slowly and sustains the flow of the river during the spring and early summer. About one-half of the snow pack in the Sierra Nevada is at moderate altitudes where temperatures are variable (Daniel Cayan, Scripps Institute of Oceanography, written commun., 1994). A cool spring can delay melting of the snow pack, resulting in reduced peak streamflow during the spring and increased streamflow during the summer.

Between 1958 and 1992, daily temperatures averaged $10.1^{\circ} \mathrm{C}$ at the south entrance station of Yosemite National Park (altitude 5,120 ft above sea level) near Wawona. At Huntington Lake, Calif. (fig. 1), the meteorological station closest to Wawona above the 7,000-ft altitude (altitude 7,020 $\mathrm{ft}$ above sea level), daily temperatures averaged $8.1^{\circ} \mathrm{C}$ for the same period. Most of the drainage area of the South Fork Merced River, which includes the Biledo Meadow area, is at an altitude that is similar to the altitude at Huntington Lake. Therefore, average daily temperature in most of the drainage area of the river is probably similar to the average daily temperatures at Huntington Lake.

Average annual precipitation at the south entrance station of Yosemite National Park was 40.8 in. for a 14-year period between 1958 and 1992 when precipitation records were complete. Precipitation at Huntington Lake averaged 42.68 in. for the same period. Huntington Lake is about 28 mi southeast of Wawona. Precipitation at Huntington Lake may not adequately represent precipitation in the South Fork Merced River basin above Wawona because this area may not receive precipitation from storms that have a more northerly track. Between 1911 and 1960, mean annual precipitation for most of the South Fork Merced River basin above Wawona was between 50 and 60 in. (Rantz, 1969). Precipitation at Biledo Meadow and at higher altitudes upstream of Wawona probably exceeded precipitation at Huntington Lake and at the south entrance station of Yosemite National Park.

\section{Water Use}

Water withdrawn from the South Fork Merced River by the National Park Service is treated and distributed to park facilities and concessionaire and park employee housing; the Wawona Hotel, store, gas station, and campground; and several private residences. The National Park Service water- distribution system also supplies water for fire protection for Wawona and occasionally supplies water to fire fighters bivouacked in Wawona.

Most of the private homes, the rental cottages, and the children's camp (Camp Wawona) use water withdrawn from wells drilled into the fractured granitic rocks underlying Wawona. A few of the private homes rely on seepage springs or shallow wells, dug in the thin alluvium near the South Fork Merced River or in the Pre-Tahoe Till.

The National Park Service sewer system collects wastewater from most of the public and private sources in Wawona. Tertiary-treated effluent from the Wawona wastewater-treatment plant is stored in large holding tanks and used for irrigating the Wawona golf course. Occasionally, excess effluent is discharged to the South Fork Merced River. Septic systems are used by Camp Wawona and by a few of the private residences on the low ridge separating the South Fork Merced River valley from the Wawona meadow.

Total water use in Wawona has not been estimated. It varies seasonally and is dependent on the number of park visitors and the number of park and concessionaire employees in residence. Readily available water-use data for 1989-91 are shown in figure 3. During the summer, water needed for irrigation exceeds the amount of effluent that is stored during the winter or that is available from the wastewater-treatment plant. Therefore, additional water is diverted from the South Fork Merced River for direct irrigation of the golf course and the lawn of the Wawona Hotel. Except for water pumped from wells at Camp Chilnualna, a privately owned cabin rental business (fig. 1), the volume of water pumped from approximately 100 privately owned wells in Wawona is unknown.

\section{Fractured-Rock Aquifers}

Fractured-rock aquifers are dual porosity systems. Storage in the aquifer equals the sum of water that can be stored in the fractures and water that can be stored in the pore spaces or matrices of the intact rock. Similarly, the ability of a fracturedrock aquifer to transmit water (hydraulic conductivity) is a function of both fracture and matrix hydraulic conductivity. Often, the volume of water stored in fractures is low compared with the volume of water stored in the rock matrix; usually, the hydraulic conductivity of fractures is much greater than that of the rock matrix. Thus, in many fractured-rock aquifers, storage properties are determined by the rock matrix and transmissive properties are determined by the fractures.

For the purpose of water supply, the matrix of unweathered granitic rocks, such as those in the 


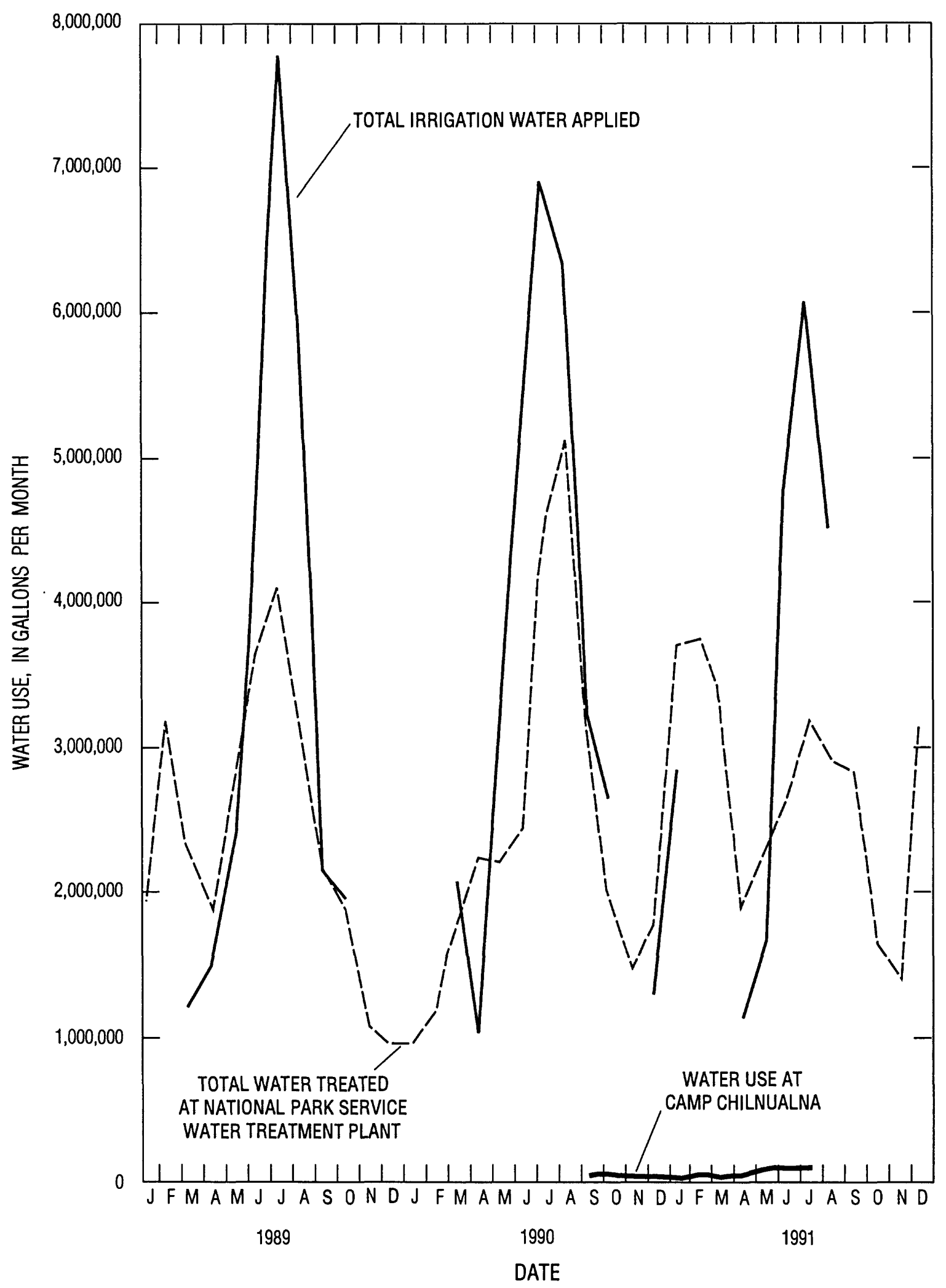

Figure 3. Monthly water use at Wawona, Yosemite National Park, California, 1989-91. 
study area, is essentially impermeable. The granitic matrix does not store or transmit significant amounts of ground water. Ground water primarily is stored in and transmitted through fractures; thus, the hydraulic properties of the granitic fracturedrock aquifer are dependent on the characteristics of the fractures, such as width of aperture, length, height, orientation, and interconnection. Fracture interconnection probably is the most important of these characteristics in determining watertransmitting properties (hydraulic conductivity, transmissivity, and permeability). The degree of fracture interconnection is highest where fractures are open, long, high, numerous, and oriented in many directions. If fractures are well connected, water can move from recharge areas to discharge points at streams, springs, and wells. If fractures are poorly connected, water is restricted from moving easily through an aquifer.

Ground-water flow in fractured rock can be influenced by the earth's stress field. Stresses deeper than a few feet into the earth are compressional forces-pressures caused by the superposition of tectonic and local stresses. Tectonic stresses generally are uniform over great distances and arise from forces that drive or resist the motion of continental and oceanic plates and from forces owing to largescale flexure of the lithosphere. Local stresses may be superposed on a regional stress field by uneven distribution of weight in areas of high topographic relief, unloading from erosion or excavation, or other causes. Because stress magnitude usually varies directionally, hydraulic properties of fractures may depend on their orientation in relation to the stress field. If mechanical properties and dimensions of fractures are similar, fractures perpendicular to maximum stress are likely to be squeezed closed, whereas fractures perpendicular to minimum stress are more likely to be open and permeable. Maximum, intermediate, and minimum principal stresses usually are orthogonal with one principal stress oriented vertically $\left(\sigma_{\mathrm{v}}\right)$ and the other principal stresses $\left(\sigma_{\mathrm{H}_{\max }}\right.$ and $\left.\sigma_{\mathrm{H}_{\min }}\right)$ oriented horizontally.

Fractures and faults form in response to applied stress. However, there may be no causative relation between the current stress field and fracture orientation (Seeburger and Zoback, 1982) because the magnitude and orientation of regional and local stresses may have changed since the fractures were formed. Ground-water flow in fractured rock is influenced by the relation between the current stress field and the orientation of the fractures.

Optimal characteristics of a fractured-rock aquifer for development of ground-water supplies include the following:

1. Intensely fractured bedrock containing open, long, high fractures oriented in many direc- tions. This characteristic maximizes storage properties and increases the chances of fracture interconnection and consequent higher transmissive properties.

2. A stress field oriented so that fractures are permeable and interconnected. This characteristic maximizes the hydraulic properties of an aquifer.

3. Thick, saturated, alluvial deposits overlying fractured bedrock. This characteristic increases the storage properties of an aquifer and provides some filtration of water recharging the aquifer.

4. Recharge capable of supporting the proposed development of an aquifer without adverse effects to flora and fauna dependent on water in the overlying alluvial deposit.

\section{Previous Studies}

Ground-water flow in the fractured granitic rocks of the Sierra Nevada is not well understood. Information on ground-water resources in Wawona is mostly anecdotal. However, well owners' records occasionally include information on well depths, water levels, and dates of water-level measurements, but the only documented data on ground-water resources in this area are a few drillers' logs on file with the California Department of Water Resources in Fresno, Calif. Historical data are not available on the chemical quality of ground water from wells and springs in the Wawona area.

A brief investigation by A.L. Franks (consultant, written commun., 1983) on the ground-water-flow system at Wawona indicated that wells properly sited in the Tonalite of the Gateway could produce between 50 and $200 \mathrm{gal} / \mathrm{min}$. However, during a later study, A.L. Franks (consultant, written commun., 1983) encountered clay-filled fractures when three test wells were drilled in the Tonalite of the Gateway. The well locations had been selected using traditional well-location techniques (seismic refraction surveys, fracture mapping at outcrops, and geomorphic analysis). The test wells were abandoned because of low yields $(12,6$, and $3 \mathrm{gal} / \mathrm{min})$.

A short report by Bryan and Taylor (1922) on water-supply alternatives for visitor facilities in Mariposa Grove (fig. 1) describes springs and seeps in the Mariposa Grove and Biledo Meadow area and provides estimates of flow from these springs and seeps. Biledo Spring was not mentioned in the report; however, it was mentioned in a letter report from the Superintendent of Yosemite National Park 
to the Director of the National Park Service. The letter report describes construction of cisterns at Biledo Spring and pipelines from the spring to Mariposa Grove and the south entrance station of Yosemite National Park (Thompson, 1931).

\section{Acknowledgments}

Kirk Helland and Dr. Charles Woessner, Wawona residents with a keen interest in geology and water resources, provided invaluable assistance for many months by collecting water samples, water-level measurements, pumping-test data, and seismic refraction data; by logging well cuttings during drilling; and by assisting during stream gainand-loss studies and hydraulic fracturing stress measurements. Martin Gerber assisted during seismic refraction surveys in the Wawona meadow. Julia Smith and Jerry Marasovich, volunteers, U.S. Geological Survey, collected and analyzed pumping-test data. Dina Kadhim, volunteer, U.S. Geological Survey, prepared maps and hydrographs. William McCaffrey, U.S. Forest Service, mapped fractures and lineaments in the granitic and metamorphic rocks in the Wawona area from aerial photographs provided by Jerome DeGraff, U.S. Forest Service.

Greg Nimz, Bryant Hudson, Marc Caffee, Bob Finkel, Lee Davisson, Sidney Niemeyer, David Smith, and Joanne Rego of Lawrence Livermore National Laboratory joined the project as coinvestigators providing isotopic and chemical analyses for more than 30 ground-water samples. Measurements of in situ stress for the two test holes were done by Stephen H. Hickman with assistance from Joseph Svitek and Gabrielle Katz, U.S. Geological Survey, and Erich Scholz of Lamount-Daugherty Geologic Observatory. Leigh House, Los Alamos National Laboratory and Hsi-Ping Liu, U.S. Geological Survey, provided the equipment and expertise to map fractures by seismic location of microearthquakes during hydraulic fracturing of granitic rock. Daroll Wood, Rick Rienke, Don Snaman, and Roger Hunter, independent consultants, contributed significant time and equipment to perform innovative fracture-mapping experiments using tiltmeters deployed in shallow cased holes during hydraulic injections in the two test holes.

Shun'ichi Kamewada and Toru Kosugi, Raax Co., Ltd., and Tim McGregor, Subsurface Imaging Incorporated, provided digital optical-televiewer logs of the shallowest $300 \mathrm{ft}$ of the test holes and loaned a Raax Borehole Image Processing System to analyze the data. Kenzi Karasaki, Lawrence Berkeley Laboratory, provided pressure-measuring and recording equipment and a borehole deviation tool. Roger Morin, Frederick Paillet, Richard
Hodges, and John Hutchens, U.S. Geological Survey Borehole Geophysics Research Project, spent many days collecting and analyzing geophysical logs from wells in Wawona. Personnel from Colog Inc. provided water-quality logs and acoustic logs for test hole 2. Niklaus Waber, University of Bern, Switzerland, analyzed the $\mathrm{Br} / \mathrm{Cl}$ (dissolved bromide to chloride) ratio of fluid inclusions in quartz from well cuttings. King Huber and Clyde Wahrhaftig (now deceased), U.S. Geological Survey, provided the project staff with an invaluable week of geologic reconnaissance in the Wawona area. Sidney Peterson, U.S. Geological Survey, provided the shaded relief map on the report cover. Teresa Rogers, California State University, Sacramento, analyzed the mineral composition of unweathered and chemically altered granitic rocks. Peter Schiffman and Norman Winter, University of California, Davis, provided electron microprobe analyses of altered granitic rocks.

Finally, sincere thanks to the many dedicated National Park Service employees who provided labor, equipment, advice, and data and to Wawona residents who allowed access to their wells. Without their help, much less would have been accomplished.

\section{METHODS OF DATA COLLECTION AND ANALYSIS}

\section{Seismic Refraction Survey}

Seismic refraction methods measure the time it takes for a compressional sound wave created by a near-surface source to travel down through layers of earth and back up to detectors placed on land surface. This method relies on the physical laws that govern the transmission of sound in layered media. Field data consist of measured distances between detectors (geophones) and seismic travel times. These data can be used to calculate variations in seismic velocity and depths to individual geologic layers. Seismic methods and analysis techniques, as applied to hydrologic studies, are discussed in detail by Haeni (1988) and were applied to the seismic refraction survey in the Wawona meadow.

Small (300 or 500 grain) black-powder charges, installed in small-diameter, hand-augered holes, were used as seismic energy sources during seismic refraction surveys in the Wawona meadow. A 24channel, signal-enhancement seismograph was used to collect, digitize, and store the seismic signals. Vertical geophones with a natural frequency of 14 hertz were spaced $50 \mathrm{ft}$ apart in a straight line from the seismic energy source. Each geophone was firmly placed in the soft soil beneath the meadow 
grasses. The relative altitude of each geophone was determined by spirit leveling so that travel times could be corrected for sloping topography. Each seismic line was reversed, that is, a charge was set off at each end of a line of geophones so that true seismic velocities could be obtained by correcting apparent velocities for dipping geologic contacts. Using this method, data from $550 \mathrm{ft}$ of the seismic refraction transect were recorded at a time. The geophones then were advanced on the same bearing with an overlap of at least two geophones on the preceding line.

The arrival time of the first compressional seismic wave was determined from the seismograph recording. A computer program by Scott and others (1972) was used to analyze the seismic data and to determine the thickness and seismic velocity of several layers specified in the input to the program. The interpretation of the arrival-time data was somewhat subjective because the seismologist specified the number of layers of different seismic velocity believed to underlie the transect (David Berger, U.S. Geological Survey, written commun., 1992). The program defined each interpreted model layer beneath the geophones receiving refracted energy from that layer. Layer boundaries then were interpolated between geophone locations.

\section{Well and Test Hole Construction}

One well and two test holes were constructed for the study. Well 5S/21E-2H1 (fig. 4) was hand augered to $10 \mathrm{ft}$ below land surface; filled with cuttings to $6 \mathrm{ft}$ below land surface; cased with a capped, slotted, 4-in. diameter pvc pipe; back-filled with sand; and grouted at the surface. This well was used to measure the depth to the water table beneath the Wawona meadow and to provide information on the nature of the sediments in the shallow subsurface.

In August 1992, test holes 1 and 2 (TH1 and TH2) were drilled to depths of 1,025 and $425 \mathrm{ft}$, respectively, using an air-rotary drilling rig equipped with a 6.75-in. percussion-hammer bit. A 7-in. steel casing, equipped with a drive shoe, was driven into the weathered granitic rocks (about $33 \mathrm{ft}$ below land surface in TH1 and about $27 \mathrm{ft}$ below land surface in TH2) and grouted in place. Borehole geophysical logs, water samples, flow-test data, and in situ stress measurement data were collected at both test holes.

Two pneumatic packers were installed in $\mathrm{TH} 2$ at depths of 232 and $307 \mathrm{ft}$ below land surface. The packers were installed in January 1993 to stop the flow of water from $\mathrm{TH} 2$ and to allow monitoring of hydraulic head and chemical quality of ground water in three separate zones of the aquifer (land surface to $231 \mathrm{ft}$ below land surface, 232 to $306 \mathrm{ft}$ below land surface, and 309 to $425 \mathrm{ft}$ below land surface). In spring of 1993, the packers failed, probably because of overinflation, and were removed. A 2-in., galvanized-steel access pipe then was grouted in place at $230 \mathrm{ft}$ below land surface, and a well-head valve was installed on the pipe to shut off flow from TH2.

\section{Fracture Mapping}

Geologic methods commonly used to describe hydrogeologic characteristics of fractured rocks include fracture-trace mapping, which was done using stereoscopic analysis of aerial photographs, and measurement of fracture orientation, spacing, and aperture at outcrops. These methods were used early in this study; however, data collected from wells proved to be of more value than data collected using these geologic methods because the wells were in areas where fracture traces are not visible.

The locations of fracture traces mapped from aerial photographs by William McCaffrey (U.S. Forest Service, written commun., 1991) were used for qualitative comparison with the locations of wells having large yields. Few fracture traces were visible on aerial photographs of the South Fork Merced River valley at Wawona because the granitic rocks were hidden by vegetation, glacial till, soil, and alluvium. Fractures mapped at outcrops verified the location of some fracture traces mapped from the aerial photographs.

\section{Borehole Geophysical Surveys}

Conventional geophysical and borehole optical tools were used to characterize fractured granitic rocks in test holes and private wells in Wawona (appendix A). The borehole tools primarily were used to locate fractures, measure fracture orientation (strike and dip), and determine if fractures were open or recemented (annealed), weathered or unweathered, and permeable or impermeable.

Caliper logs were used to locate fractures by providing a continuous record of borehole diameter. Borehole diameter usually increased where fractures intersected the borehole and where granitic rocks are weathered or decomposed. A decrease in the resistance of rock to the flow of electric current on electrical resistivity logs (point resistance and 16and 64-in. normal and lateral resistivity) indicated the presence of fractures and associated weathered or altered zones. Natural gamma logs indicate variations in the amount of gamma-ray-emitting radiogenic elements in the plutonic rocks. An 


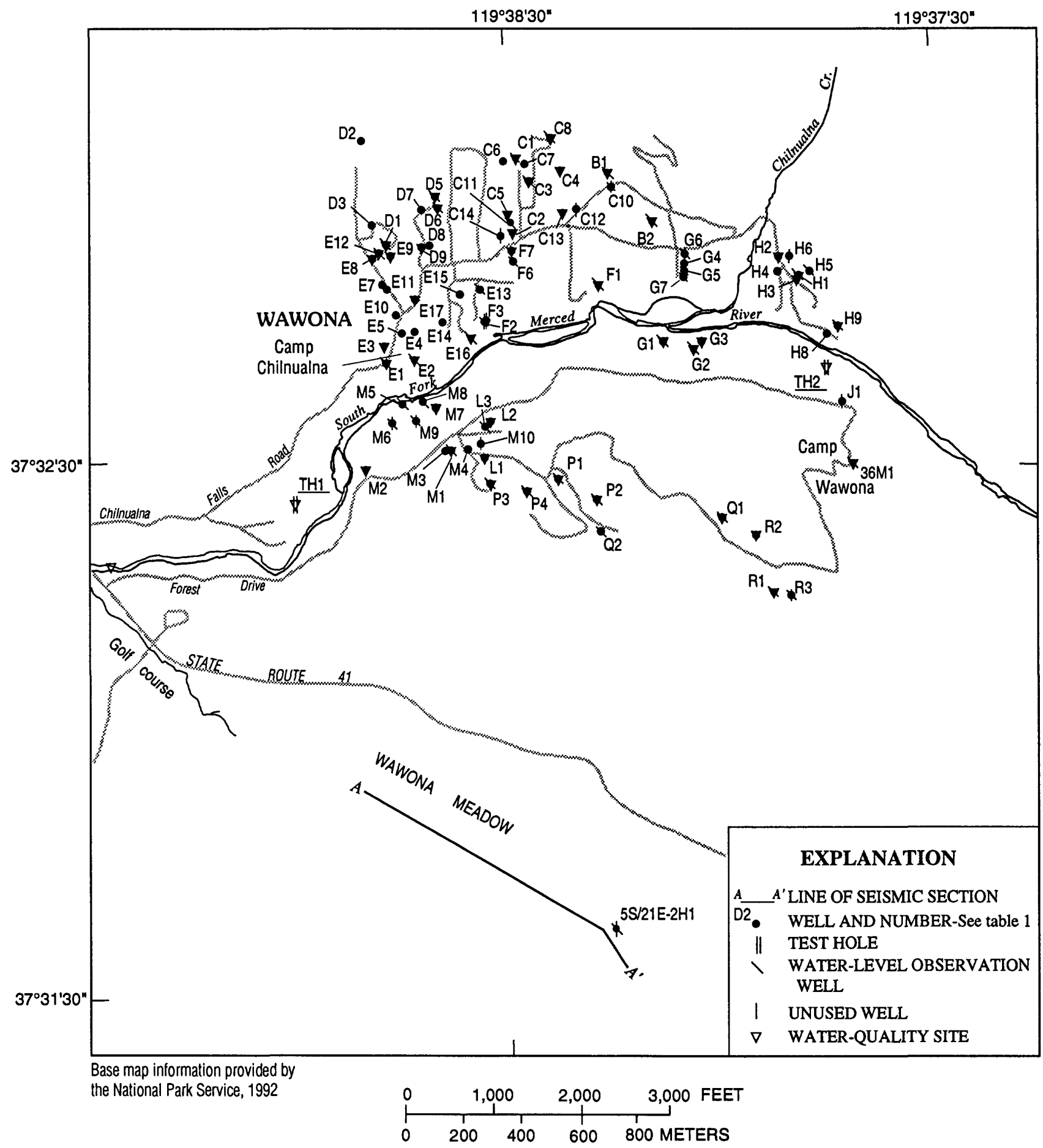

Figure 4. Location of wells, test holes, and stream water-quality site in the Wawona area, Yosemite National Park, California. 
acoustic $\log$ of $\mathrm{TH} 2$ indicates fractures by a decrease in the amplitude of the first sound wave arriving at a detector after reflecting from the borehole wall and by a decrease in velocity and amplitude of a tube wave, a sound wave that travels up the borehole.

Acoustic televiewer (ATV) logs provide an image of the sound-reflective properties (acoustic reflectivity) of a borehole wall. The ATV images are centered to the south, allowing the orientation (strike and dip) of fractures in $\mathrm{TH} 1$ and $\mathrm{TH} 2$ to be measured from the images (fig. 5).

Borehole television scans were used to provide qualitative information (color, shape, relative size, etc.) about fractures that had previously been identified using other methods. Some features of the granitic rocks (mafic inclusions, dikes, mineral veins, annealed fractures, etc.), which were not discernable using conventional borehole geophysical methods, were identified using television scans of TH1 and TH2.

Digital optical-televiewer logs of the upper 300 $\mathrm{ft}$ of each test hole contained almost the same qualitative information as borehole television scans and more quantitative information than the ATV logs. The digital optical-televiewer logs provided a color, optical image of the borehole wall oriented north. The optical images are similar to the ATV images (fig. 5) because they represent a flat map of the borehole wall; however, the image of the digital optical-televiewer logs is centered to the north rather than to the south. Data used to produce the digital optical images were collected by a borehole television camera and transmitted as a video signal uphole to an electronics module that digitized the signal at a resolution of about 0.05 in. in both the vertical and radial dimension. When images were displayed on a 24-bit color computer monitor, automated processing software allowed the orientation and aperture of fractures, faults, and dikes to be measured.

Heat-pulse and impeller flowmeters were used to indicate which fractures supplied water to the boreholes and to determine the direction of flow in the boreholes under pumped and unpumped conditions. Fluid-resistivity and fluid-temperature logs were sometimes helpful in discerning fractures that contributed ground water with a different temperature or containing a different concentration of dissolved solids than ground water from other fractures. Fracture permeability was not measured. It is possible that some of the fractures that were designated as impermeable during flowmeter logging would be permeable if effective stress normal to the fracture were decreased by higher hydraulic head within the fracture, by relaxation of earthtide-induced compression normal to the fracture, or by other means.
Fracture-orientation data collected from vertical boreholes underrepresents vertical fractures. This is not significant to the results of this study because the hydraulic characteristics of the aquifer were not estimated using models that rely on fracture orientation and frequency. Instead, the relation between fracture orientation and in situ stress was used to conceptualize the ground-water-flow system.

\section{In Situ Stress Measurement}

In situ stress (pressure within the earth) was measured at several depths in TH1 and TH2 using the hydraulic-fracturing method. This method relies on theoretical relations between (1) the orientation of a hydraulic fracture created during a measurement of in situ stress and principal stress directions and (2) fluid pressure during hydraulic fracturing and the magnitude of principal in situ stresses.

To make an in situ stress measurement, a 7 -ft section of borehole having no fractures, mineral veins, or other flaws was isolated with inflatable rubber packers and pressurized by pumping water into the isolated interval at a slow rate. The rate of flow and pressure in the isolated interval was monitored during each stress measurement. Pressure in the isolated interval increased until a breakdown pressure was reached and the rock at the borehole wall cracked tensilely. Continued pumping caused the fracture to propagate outward from the borehole. When pumping ceased, the fracture stopped propagating, and, when pressure in the interval declined, the fracture closed. Several cycles of pumping were done at each interval so that fracture reopening pressure could be determined. Fracture reopening pressure is the pressure at which the hydraulic fracture opened and began to accept water pumped into the interval during subsequent pumping cycles. Fracture reopening pressure is proportional to minimum horizontal stress $\left(\sigma_{\mathrm{H}_{\min }}\right)$.

The orientation of a hydraulic fracture was determined by inflating an impression packer to a pressure slightly above the fracture reopening pressure. The impression packer remained inflated for about 1 hour, allowing its uncured rubber coating to extrude slightly into the hydraulic fracture. A photograph of a compass securely mounted inside the impression packer defined the orientation of the packer assembly in relation to magnetic north. The impression packer then was deflated allowing the hydraulic fracture to close, pinching off a small amount of the extruded rubber and leaving a raised ridge on the surface of the packer. When the impression packer was removed from the test holes, the strike and dip of the hydraulic fracture was determined by the orientation of the raised ridge on the packer surface and the orientation of the packer assembly during inflation. 

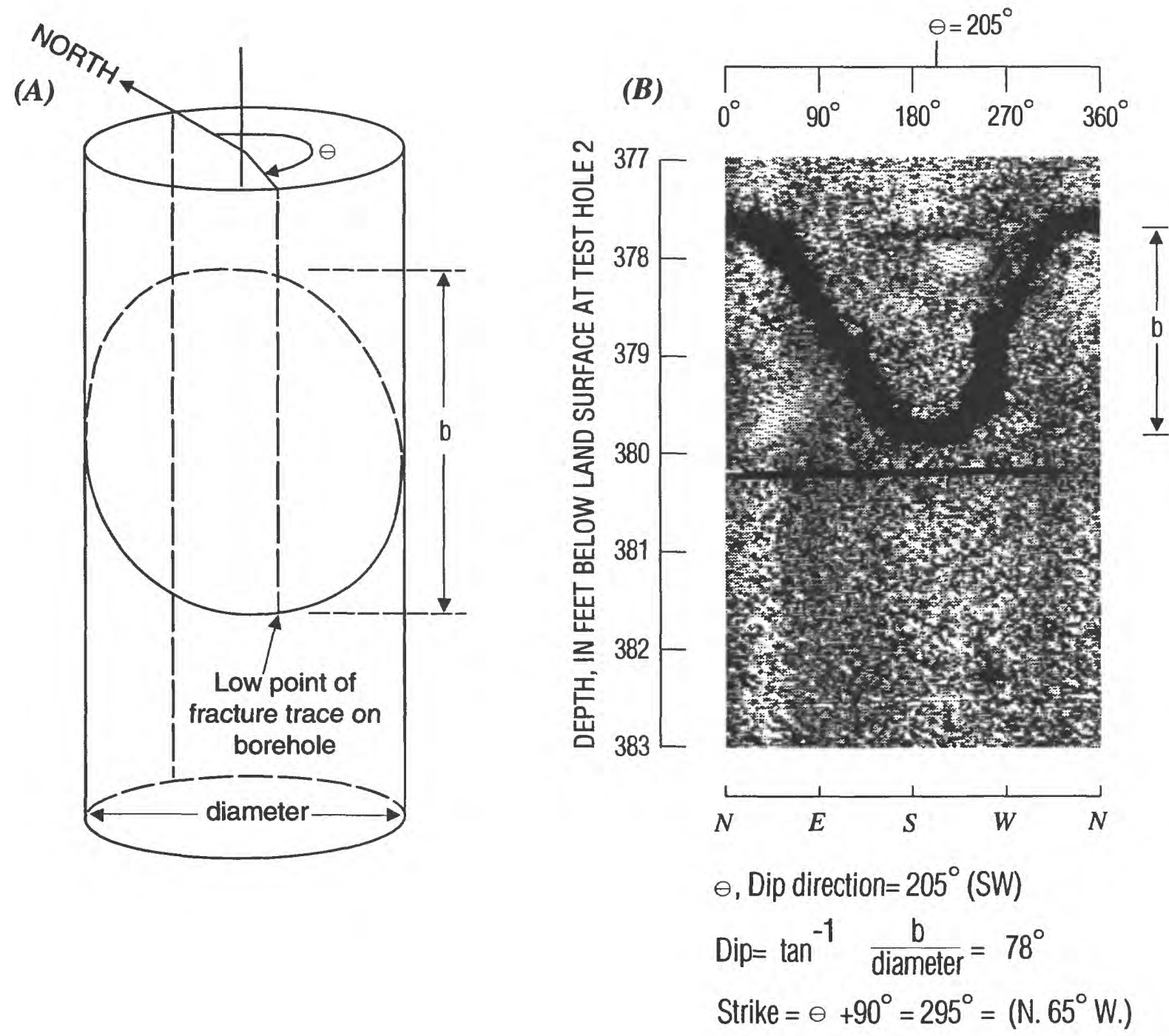

Figure 5. Determination of fracture orientation from acoustic televiewer log of test hole 2 in the Wawona area, Yosemite National Park, California: $(A)$ fracture intersecting the test hole and $(B)$ acoustic televiewer image of test hole.

Measuring the orientation of each hydraulic fracture provided the orientation of two of the three principal stresses in each tested interval. Stress conditions at a borehole wall cause hydraulic fractures to be vertical, perpendicular to the direction of minimum horizontal stress, and parallel to the direction of maximum horizontal stress. The orientation of a hydraulic fracture, therefore, defines the orientation of minimum and maximum horizontal stress. The third principal stress was assumed vertical because extensive field evidence has shown that one principal stress is vertical at most locations (Haimson, 1978).
The magnitude of vertical compressive stress $\left(\sigma_{\mathrm{y}}\right)$ was calculated from the weight of rock overlying the hydraulically fractured interval. Estimates for the magnitudes of the principal horizontal stresses $\left(\sigma_{\mathrm{H}_{\max }}\right.$ and $\left.\sigma_{\mathrm{H}_{\min }}\right)$ were determined using theoretical expressions developed for linearly elastic and isotropic rocks, pressure measurements during hydraulic fracturing, and estimated data on the tensile strength, permeability, and pore pressure in the rock. Published data on the tensile strength of granitic rocks (Goodman, 1980) provided a range of values used to estimate stress magnitude. The granitic rocks were assumed to be impermeable and 
pore pressure was assumed equal to hydrostatic head. Only the relative magnitudes of the three principal stresses are considered in this report. For a more detailed description of techniques for estimating stress magnitude, the reader is referred to Haimson (1978) and Hickman and Zoback (1983).

\section{Water Sampling and Analysis}

Standard field methods were used to collect and preserve samples for laboratory analysis (U.S. Geological Survey, 1980). Most ground-water samples for chemical analysis were collected using existing well pumps and plumbing. Flowing wells were sampled without pumping. Springs were sampled using peristaltic pumps at the point where ground water flowed into the spring pool. Grab samples were collected from two streams.

Prior to sampling for major inorganic and traceelement constituents in late August 1991, a minimum of three wellbore volumes of water were pumped or allowed to flow from the wells to ensure the representativeness of the ground-water samples. Water levels, pumping time, pump discharge, temperature, $\mathrm{pH}$, specific conductance, and dissolvedoxygen concentrations were recorded for water discharged during the wellbore purge. After sample collection, water-level recovery was monitored and depth to the shallowest water-bearing fracture was estimated by measuring the water level at which water no longer cascaded noisily into the wellbore.

In September 1991, wells at Wawona were sampled for stable isotopes and tritium using the same wellbore-purging procedure used during sampling for major inorganic and trace-element constituents, except that contact with the atmosphere was minimized by maintaining the water level above the shallowest water-bearing fracture. In low-yielding wells, many cycles of pumping and recovery were required to obtain an adequate purge while preventing ground water from cascading into the well bore.

Major inorganic and trace-element samples were analyzed by the U.S. Geological Survey National Water Quality Laboratory in Arvada, Colo., using standard methods of analysis (Fishman and Friedman, 1989). Stable-isotope and tritium samples were analyzed at the Isotope Fractionation Laboratory of the U.S. Geological Survey in Reston, VA. Ground-water samples were analyzed at the National Water Quality Laboratory using liquid scintillation techniques to determine dissolved ${ }^{222}$ radon. All analyses were checked to verify that milliequivalent concentrations of positively and negatively charged ions balanced to within 3 percent. WATEQ4F, a Fortran computer program that calculates the saturation of a water sample with respect to common, naturally occurring minerals, was used to indicate geochemical reactions that may occur in the ground-water-flow systems in the Wawona area.

Biledo Spring was sampled for Giardia using a procedure described by Sorenson and others (1986). One hundred gallons of water was pumped through a 2-micron, fiberglass epoxy filter. The filter then was double sealed in sterile plastic bags for transport to the U.S. Geological Survey Giardia Laboratory in Sacramento, Calif. The immunofluorescence method (Riggs and others, 1983) was used to analyze for Giardia cysts.

Quartz crystals-hand picked from well cuttings at $\mathrm{TH} 1$ and $\mathrm{TH} 2$ - were used to determine the ratio of dissolved bromide to dissolved chloride $(\mathrm{Br} / \mathrm{C} 1)$ in fluid inclusions in the granitic rocks at Wawona. After the quartz crystals were rinsed with deionized water and dried, they were crushed and rinsed again with deionized water to leach inclusion fluids. The leachate was analyzed by ion chromatography to determine the concentrations of dissolved bromide and chloride from which the $\mathrm{Br} / \mathrm{Cl}$ ratio then was computed. This work was done by the Rock-Water Interaction Group at the University of Bern, Switzerland.

\section{Stream Gain-and-Loss Studies}

Stream gain-and-loss studies are designed to determine the magnitude of streamflow gained from ground water discharging to a stream or the magnitude of streamflow lost to the ground-water system when stream water infiltrates the riverbed. Gainand-loss studies are a quick method of quantifying the interaction between surface and ground water at a given moment in time. This interaction can be quantified for each stream reach by subtracting tributary inflow and by comparing upstream to downstream discharge.

During each gain-and-loss study on the South Fork Merced River and Rainier Creek and at the mouths of tributaries, a series of stream-discharge measurements were made following standard field procedures for velocity-area, Parshall flume, or volumetric methods (Buchanan and Somers, 1969). One day prior to each gain-and-loss study, each site to be measured using the velocity-area method was improved by removing obstructions to flow, leveling the stream bottom, and preparing parallel streambanks. Care was taken to ensure that flow was distributed evenly in each measured section. The intake to the Wawona water-treatment plant was shut off 1 day prior to each gain-and-loss study on the South Fork Merced River and remained off until measurements were completed so that only natural streamflow variations were measured. Each gain-and-loss study was completed within 1 day. 
Errors associated with stream-discharge measurements are additive when discharge measurements are subtracted to determine flow gain or loss in a reach. If stream discharge is high and flow gain or loss is low, measurement error can exceed the computed gain or loss. In that case, gains and loses might be inferred but can not be quantified accurately. Because the sum of possible measurement errors usually was greater than the computed gain or loss for each reach, gain-and-loss studies were repeated several times for each stream during the summers of 1991 and 1992 to determine if the reach appeared to consistently gain or lose flow.

\section{GROUND WATER IN THE SOUTH FORK MERCED RIVER VALLEY AT WAWONA}

\section{Unconsolidated Deposits}

Unconsolidated deposits were mapped in three areas of Wawona (Huber and others, 1989): the Pre-Tahoe Till on a low ridge that separates the South Fork Merced River valley from the Wawona meadow; alluvium in the valley of the South Fork Merced River; and alluvium in the Wawona meadow (fig. 2). Although unconsolidated deposits occur over much of the Wawona area (fig. 2), these deposits are relatively unimportant to the groundwater-flow system because they are thin, poorly permeable, or mostly unsaturated.

The Pre-Tahoe Till has little potential for development of water supplies for Wawona because the till is thin and probably poorly permeable and because natural discharge from the till is large and probably necessary to sustain the forest. The PreTahoe Till is more than $15 \mathrm{ft}$ thick where it crops out at road cuts; a driller's log indicates that the till is about $20 \mathrm{ft}$ thick near well 4S/21E-35R1 (R1, fig. 4). Excavations for water lines and outcrops at road cuts showed that the Pre-Tahoe Till consists of massive boulders, cobbles, sand, and clay. Because tills are poorly sorted, that is, a heterogeneous mix of coarse, medium, and fine-grained materials, they usually have low hydraulic conductivity. Lateral movement of water through the Pre-Tahoe Till in wide, flat areas of the ridge apparently is slow enough that a thin aquifer has formed above the contact with the underlying granitic bedrock. The ridge top location of the till allows water to drain from it laterally near the contact with the underlying granitic rocks. Several dry, unused, hand-dug wells were located during field reconnaissance for this study. Well 4S/21E-35R3 (R3, fig. 4), dug 17 $\mathrm{ft}$ deep into the till, was abandoned because water production was insufficient during the dry season (Daniel Guthrie, Camp Wawona, oral commun., 1992). Water-level measurements for this well show that the saturated thickness of the till varies seasonally by as much as 50 percent (appendix B) indicating that natural discharge from the till could be about half of its ground-water-storage capacity. Ground water in the till probably sustains the ridgetop forest and supplies some recharge to underlying fractured rocks, but the till has not been a reliable source of water supply to wells.

Alluvium in the South Fork Merced River valley includes recently deposited channel and floodplain materials and older terrace deposits. Channel and floodplain materials are coarse-grained sand, cobbles, and boulders contained in relatively thin and discontinuous deposits. Occasionally, bedrock crops out in the river, streambanks, and at the border of the floodplain. Because bedrock does not crop out in the river and rarely is exposed in the river banks for about $1 \mathrm{mi}$ upstream of the mouth of Chilnualna Creek, channel and floodplain materials could be thicker in the upstream reach. Recently deposited channel and floodplain materials are hydraulically well connected to the river. Pumping of wells in the channel and floodplain materials of either reach could reduce streamflow in the river.

Other terrace deposits adjacent to the South Fork Merced River consist of boulders, cobbles, sand, and clay and are thicker than river channel and floodplain materials. Excavations done during construction of buildings, test wells, and water lines indicate that these deposits are unsaturated on the north side of the river and probably are unsaturated throughout the South Fork Merced River valley.

The thickness of alluvium in the Wawona meadow is unknown. Bedrock is not visible in the meadow and no wells have been drilled to bedrock in this area. A seismic refraction survey done along the center of the Wawona meadow in July 1991 confirmed the depth of the shallow water table when holes, bored for placement of seismic energy sources, encountered the water table. The survey also indicated that competent, unweathered granitic bedrock is as deep as $125 \mathrm{ft}$ below land surface (fig. 6). Interpretation of the seismic refraction data was hampered by a lack of subsurface geologic data needed to calibrate geophysical models of the meadow subsurface (David Berger, U.S. Geological Survey, written commun., 1992).

The seismic velocity of materials between the water table and the top of competent, unweathered granitic bedrock is 4,900 to $8,900 \mathrm{ft} / \mathrm{s}$ (fig. 6); this velocity could represent either bouldery and cobbly alluvium or weathered granitic rock. However, neither bedrock nor bouldery, cobbly alluvium were encountered during construction of water-level observation well 5S/21E-2H1-a 10-ft deep borehole that was hand augered near the center of the Wawona meadow in July 1992. The borehole passed through a thin unsaturated zone and a 


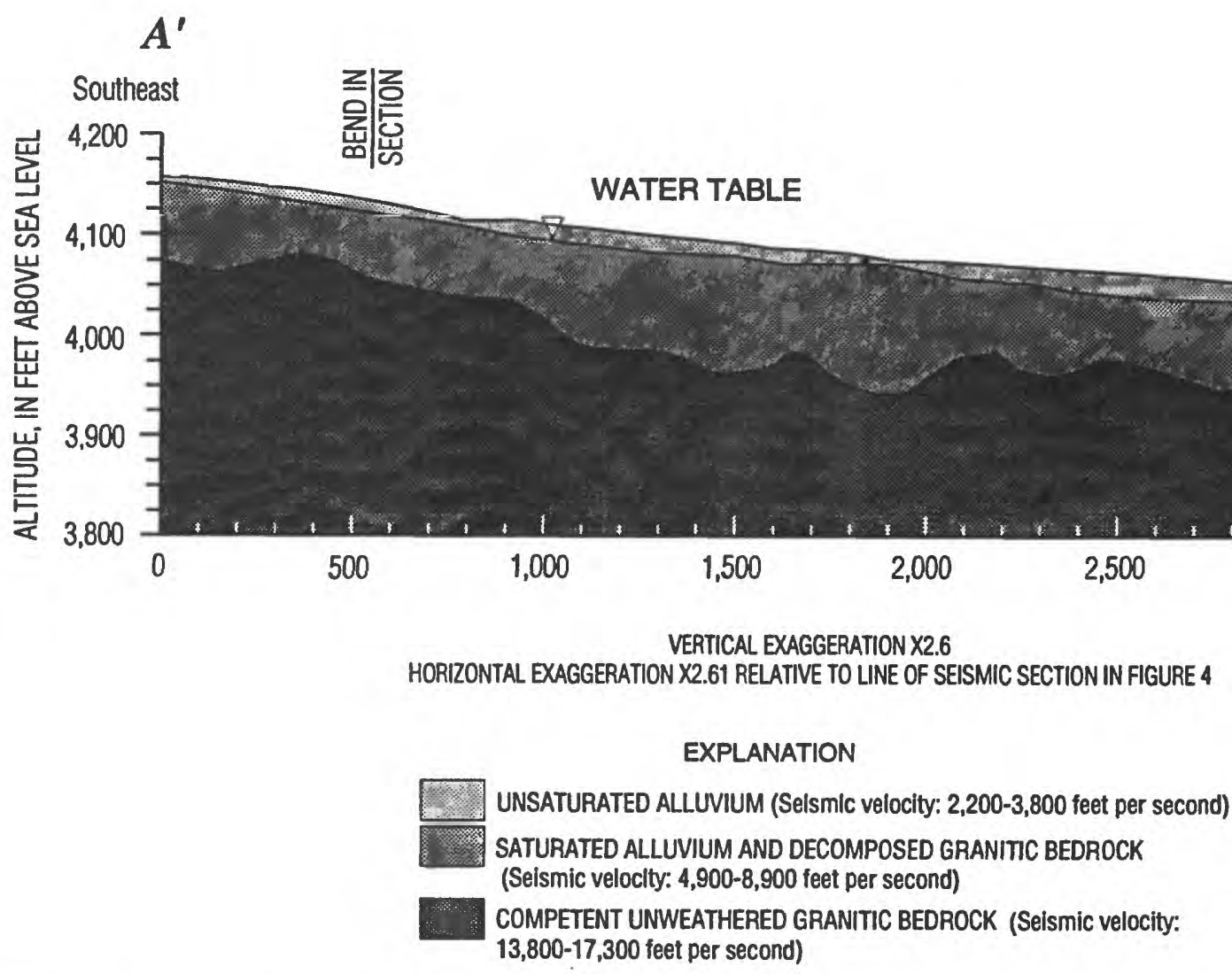

Figure 6. Seismic cross section, Wawona meadow, Yosemite National Park, California. (Interpretation and figure by David Berger, U.S. Geological Survey, written commun., 1992.)

saturated zone consisting of alternating layers of sandy clay and clayey sand, which sporadically contained small angular pieces of granitic rock, and buried soil horizons, which contained decomposing organic material. Because the borehole was shallow, little geologic information could be obtained for interpretation of the seismic velocity of the subsurface materials.

The geomorphic setting of the Wawona meadow indicates that the material between the water table and the top of competent, unweathered granitic bedrock is not cobbly alluvium. It is unlikely that coarse-grained sedimentary materials and surface-water flows adequate to transport and deposit these materials (fig. 6) could have been generated within the small $\left(4 \mathrm{mi}^{2}\right)$ drainage area upstream from the Wawona meadow. It is more likely that the meadow alluvium is thin and that most of the material between the water table and the top of the unweathered bedrock is weathered, fractured granitic rock. The alignment of the valley containing the Wawona meadow with the South Fork Merced River valley downstream from Wawona (fig. 2) indicates that northwest-striking fractures have weakened bedrock in these areas.
Fluctuations of the water table in the shallow alluvium are small and the water table remains near land surface throughout the year. The water level in well $5 \mathrm{~S} / 21 \mathrm{E}-2 \mathrm{H} 1$ ( $6 \mathrm{ft}$ in depth) stayed within 4 $\mathrm{ft}$ of land surface between July 1992 and October 1993 (appendix B). Water that ponds in ditches behind small concrete dams on both sides of the meadow probably helps to maintain the shallow water table. Grasses and sedges growing lushly in the meadow are reliant on the shallow water table that is recharged by direct infiltration of winter precipitation.

The alluvium beneath the Wawona meadow has little potential for ground-water development because the alluvium probably is thin and can store only a small volume of water, because recharge, which is dependent on precipitation over a small drainage area is small, and because the meadow ecosystem is dependent on the shallow water table that would drop in response to pumping ground water from the alluvium.

At Wawona, unconsolidated deposits contain little useable water. Fractured granitic rocks, which supply most private wells in Wawona, have greater potential for development. 


\section{Fractured Granitic Rocks}

\section{Hydrogeologic Framework}

The primary aquifer at Wawona is the fractured granitic rocks in the South Fork Merced River valley. The relation between the orientation of permeable fractures and the earth's stress field, measured in the test holes drilled for this study, indicates that most permeable fractures are not perpendicular to maximum compressive stress and that fracture interconnection decreases with depth, segregating a local, shallow ground-water-flow system from ground water in deeper fractures.

In situ stress measurements were made at seven depths between 200 and $900 \mathrm{ft}$ below land surface in TH1, a 6.75-in., open-rock hole drilled to 1,027 $\mathrm{ft}$ below land surface in the Tonalite of the Gateway. In situ stress measurements were made at four depths between 175 and $400 \mathrm{ft}$ below land surface in TH2, a 6.75-in., open-rock hole drilled to $425 \mathrm{ft}$ below land surface in the El Capitan Granite. These measurements were used to determine the orientation of maximum, intermediate, and minimum components of the earth's stress field beneath the valley floor at Wawona. The principal components were assumed to be orthogonal with one component oriented vertically $\left(\sigma_{\mathrm{v}}\right)$ and two components oriented horizontally $\left(\sigma_{\mathrm{H}_{\max }}\right.$ and $\left.\sigma_{\mathrm{H}_{\min }}\right)$.

Maximum horizontal stress is oriented N. $50^{\circ}$ W. plus or minus $10^{\circ}$ at $\mathrm{TH} 1$ and $\mathrm{TH} 2$ regardless of the depth of the measurement. The orientation of minimum horizontal stress is assumed perpendicular to maximum horizontal stress at about $\mathrm{N} .40^{\circ} \mathrm{E}$. In TH1, vertical stress is less than minimum horizontal stress at depths of less than about $600 \mathrm{ft}$ below land surface; but at depths deeper than about $600 \mathrm{ft}$, vertical stress exceeds minimum horizontal stress. A similar rotation of least compressive stress from vertical to horizontal probably occurs at about 600 $\mathrm{ft}$ below land surface at TH2, but this could not be verified because TH2 is only $425 \mathrm{ft}$ deep.

The orientation and relative magnitude of the three principal stresses in the subsurface of the South Fork Merced River valley at Wawona is conceptualized in figure 7. At depths between land surface and about $600 \mathrm{ft}$ below land surface (zone $1)$, least compressive stress is vertical. In zone 1, subhorizontal fractures are perpendicular to least compressive stress and theoretically are more likely to be open and permeable than fractures oriented in other directions. Geophysical logs of TH1 and TH2 (appendix A) show that the shallowest permeable fractures in zone 1 are subhorizontal (dip angle less than $30^{\circ}$ ). Subhorizontal fractures in the shallower parts of zone 1 may be sheeting joints-fractures that form from erosional stress-release processes, or as Jahns (1943) phrased, from "diminution of pri- mary confining pressure by removal of superincumbent load." In the deeper parts of zone 1, sheeting joints probably do not form, and therefore the frequency of permeable subhorizontal fractures is greatest at shallow depths.

At depths of about $600 \mathrm{ft}$ to depths probably on the order of miles (zones 2 and 3), vertical stress is the intermediate compressive stress. At these depths, compression from the weight of overburden exceeds minimum horizontal stress. In zones 2 and 3 , as in the deeper parts of zone 1 , sheeting joints probably do not form and other horizontal fractures probably are squeezed closed and thus are not permeable. Geophysical logs for TH1 and TH2 show that deep permeable fractures are not subhorizontal but dip steeply (dip angle usually greater than $60^{\circ}$ ) (appendix A).

Horizontal stresses $\left(\sigma_{\mathrm{H}_{\text {max }}}, \sigma_{\mathrm{H}_{\text {min }}}\right)$ in the deep, regional stress field (zone 3 , fig. 7 ) have nearly the opposite direction of the horizontal stresses at shallower depths (zones 1 and 2). Stress directions in zone 3 are inferred from Zoback and Zoback (1989) and are assumed to have a tectonic source. Information is not available on fracture orientation and permeability in zone 3 because the test holes and wells at Wawona terminate in zones 1 or 2. The valley-parallel orientation of $\sigma_{\mathrm{H}_{\max }}$ in the two shallower zones (1 and 2) indicates that shallow horizontal stress may be topographically induced and may vary with the valley orientation (Hickman and others, 1993).

On the basis of data from TH1 for depths from land surface to $900 \mathrm{ft}$ below land surface, and perhaps much deeper, orientation of maximum and minimum horizontal stresses are constant, about $\mathrm{N}$. $50^{\circ} \mathrm{W}$. and about N. $40^{\circ}$ E., respectively (fig. 7). Steeply dipping fractures that strike to the northwest are favorably oriented to be permeable because they are perpendicular to minimum horizontal stress. Fractures in TH1, TH2, and wells R1 and 36M1 strike primarily to the northwest (fig. 8). The strike and dip of permeable fractures in TH1 and TH2 are shown in appendix A. The northwest trend of permeable fractures (fig. 9) could simply reflect the fact that most fractures, permeable and impermeable, generally strike to the northwest. However, northwest-striking fractures are more likely to be permeable because they are favorably aligned with the stress field, as in TH1 and TH2. Fractures striking in other directions are less likely to be permeable.

A simple conceptual model of the fracturedrock aquifer in the valley floor at Wawona is illustrated in figure 10. Permeable, northwesttrending, steeply dipping fractures occur at all depths in the model. At shallow depths (within a few hundred feet of land surface) where vertical 


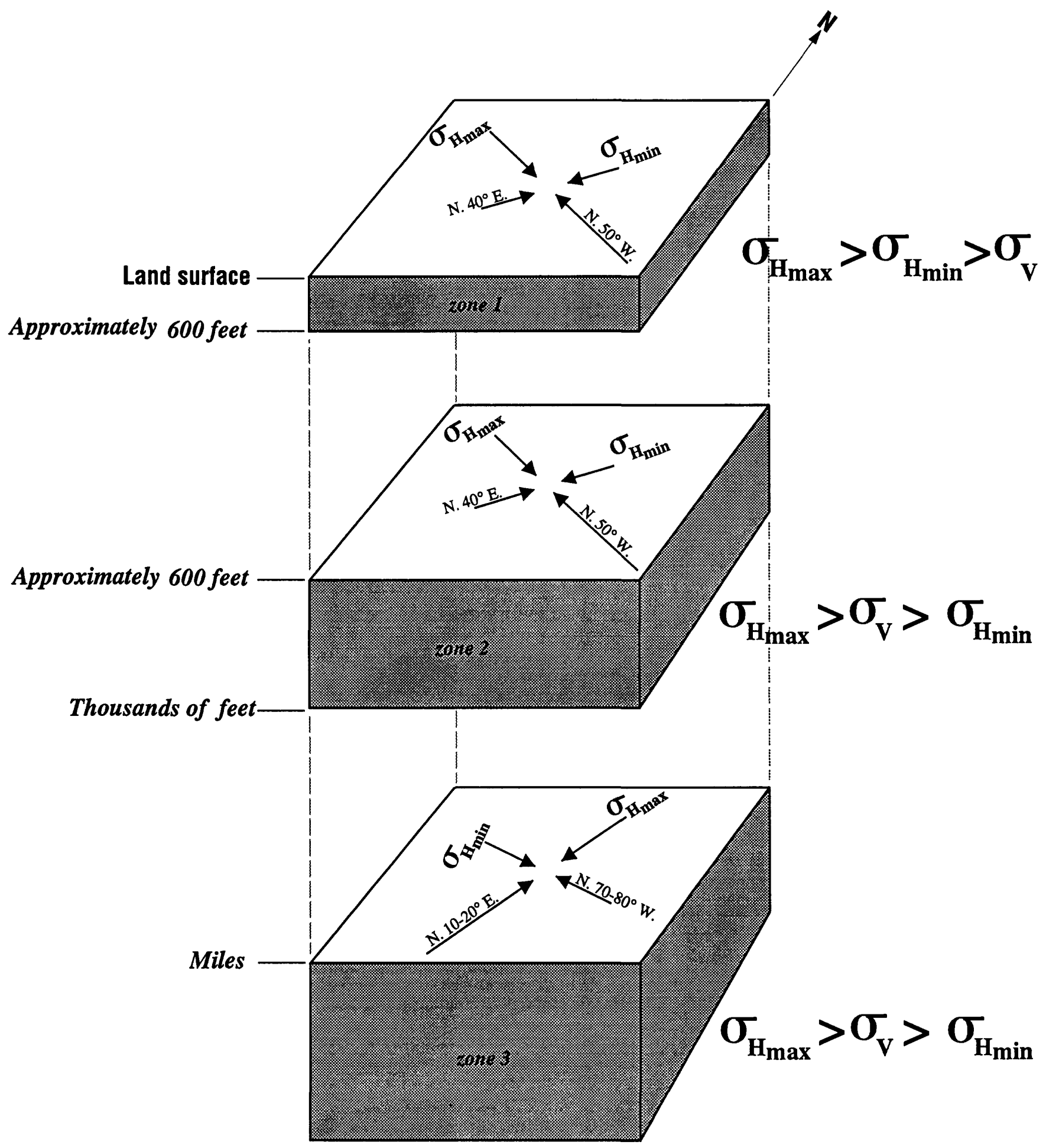

Figure 7. Orientation and relative magnitude of vertical and horizontal stresses in rocks beneath the South Fork Merced River valley at Wawona, Yosemite National Park, California. (Orientation and relative magnitude of stress in zone 3 is inferred from Zoback and Zoback, 1989).

stress is at a minimum, these steeply dipping fractures are hydraulically connected by subhorizontal fractures. Deeper in the aquifer where vertical stress is greater, permeable subhorizontal fractures are absent or less frequent, and permeable, northwest-trending, steeply dipping fractures are hydraulically isolated. If permeable, northwesttrending, steeply dipping fractures have a finite vertical dimension (limited height), the absence of horizontal connecting fractures at depth could act to restrict the interchange of ground water between the shallow and the deeper parts of the aquifer. 


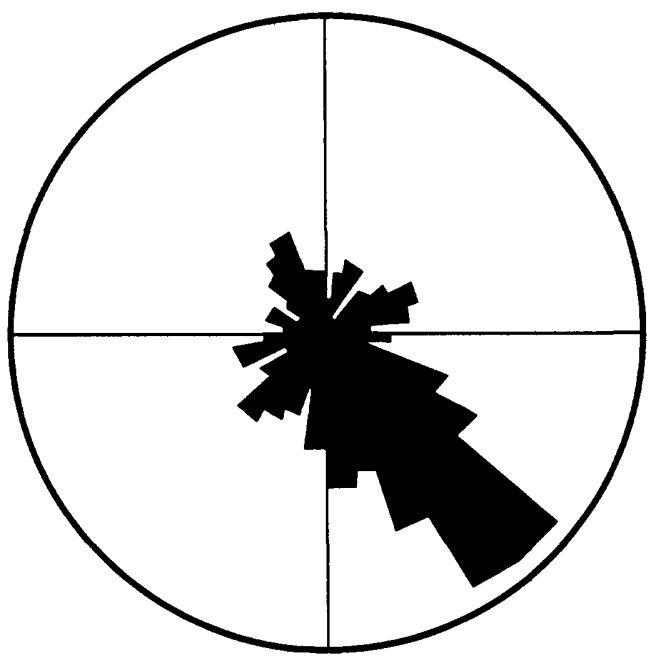

Figure 8. Strike direction for 227 fractures as determined by acoustic televiewer logs of test holes 1 and 2 and wells R1 and 36M1 in the Wawona area, Yosemite National Park, California. Dip direction is determined by the hemisphere in which the strike orientation is plotted, east or west. The circle radius equals 10 percent of the total number of fractures (227). Strike directions are grouped in 10 degree increments.

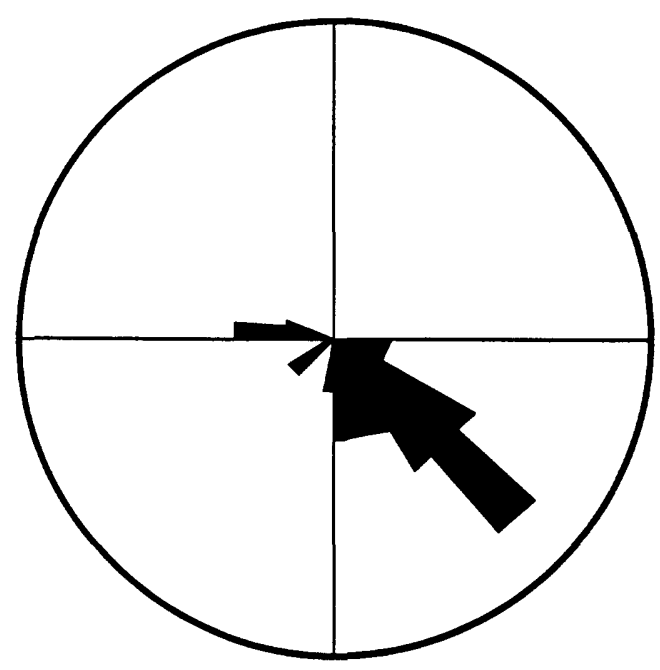

Figure 9. Strike direction for 25 permeable fractures as determined by acoustic televiewer logs of test holes 1 and 2 and wells R1 and 36M1 in the Wawona area, Yosemite National Park, California. Dip direction is determined by the hemisphere in which the strike orientation is plotted, east or west. The circle radius equals 25 percent of the total number of fractures (25). Strike directions are grouped in 10 degree increments.

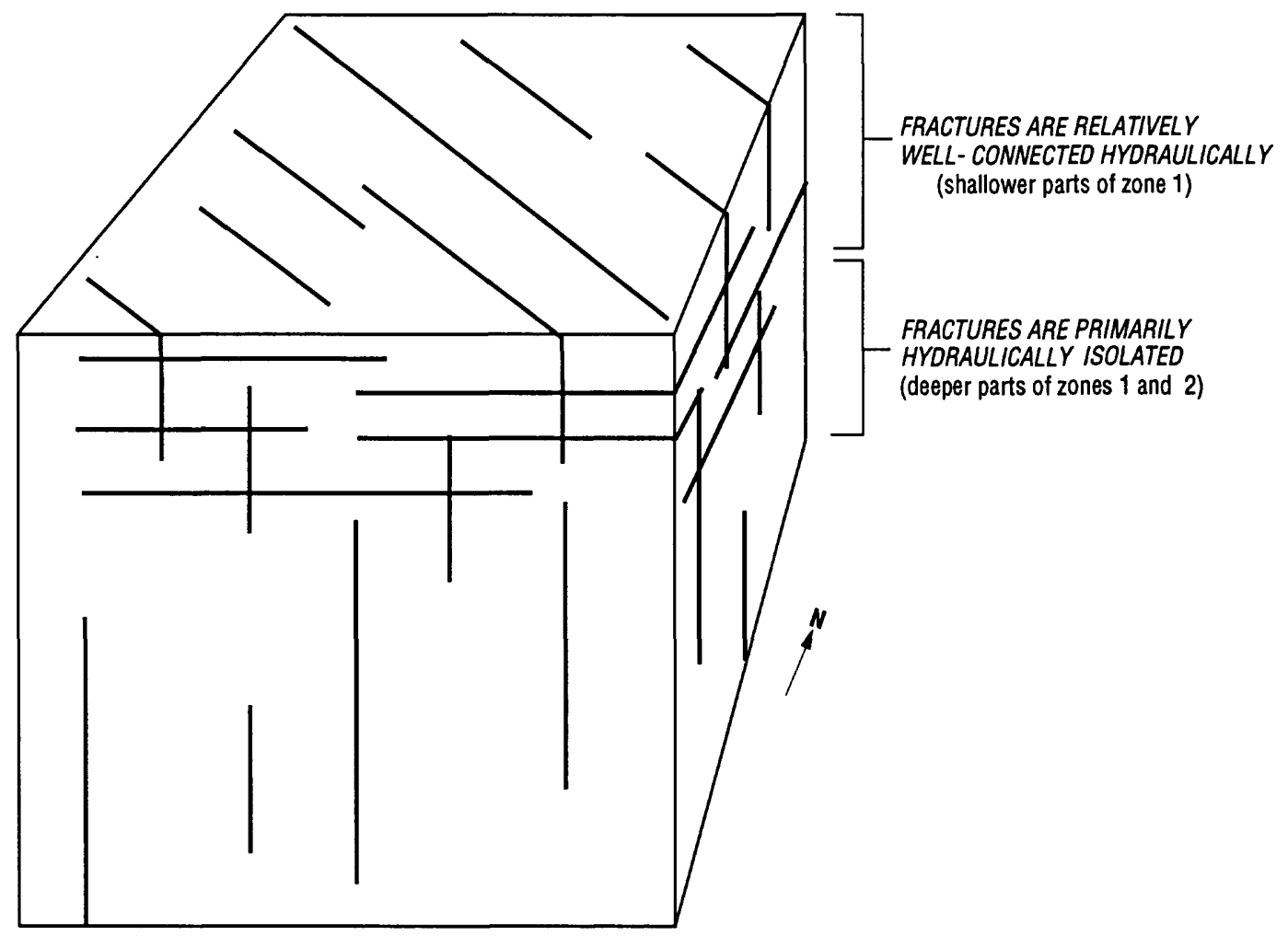

Figure 10. Conceptual model of the fractured-rock aquifer beneath the valley floor at Wawona, Yosemite National Park, California, showing permeable fractures (primarily shallow horizontal fractures and northwest-trending, steeply dipping fractures). 
The pathway for recharge to deep, hydraulically isolated fractures beneath the valley floor is not obvious. The orientation and magnitude of stresses around valleys in areas of high topographic relief vary greatly with location and depth (Goodman, 1980). The stress field in rocks distant from the test wells may be considerably different than the stress field in the valley floor. Recharge to deep fractures in the valley floor could occur through large vertical joints or other fractures that are visible on aerial photographs of upland areas. Deep, permeable subhorizontal fractures were encountered in well R1 (appendix A), which is located on the ridge top between the South Fork Merced River valley and the Wawona meadow. Stress measurements were not made in this well and conditions that make these fractures permeable are not obvious. Similar fractures might connect steeply dipping upland fractures and allow infiltrating snowmelt from the upland areas to flow toward the valley. The boundaries of the flow system containing ground water in deep fractures have not been defined. Flow paths between the recharge areas and the fractures intersected by the test wells at Wawona are not well understood.

The conceptual model of the fractured-rock aquifer at Wawona is based on in situ stress and borehole geophysical data from a small number of wells and test holes in the South Fork Merced River valley. The model may not adequately consider the relation between fracture orientation and faulting environment (thrust, normal, or strike slip) in each zone. However, the model does provide a physically plausible explanation for the large differences in hydraulic head and water chemistry between shallow and deep ground water in the South Fork Merced River valley.

\section{Ground-Water Flow}

Ground water flows from areas of high hydraulic head to areas of low hydraulic head. Hydraulic head is the elevation of water in wells above an arbitrary datum, such as sea level. At Wawona, hydraulic head was estimated using water-level and pressure-gage measurements in 38 privately owned wells and is expressed as altitude above sea level. The water-level altitudes of 35 shallow wells (less than about $300 \mathrm{ft}$ in depth) or in wells that produce ground water from only shallow fractures approximately defines the water-table altitude at Wawona (table 1, figs. 11 and 12). Hydraulic head and direction of ground-water flow in shallow, fractured granitic rocks from areas of recharge to areas of discharge are shown in figures 11 and 12 .

Ground water in shallow, fractured rock flows toward the valley floor from hillsides adjacent to the valley (generally perpendicular to the contours of hydraulic head shown in figures 11 and 12). Figures 11 and 12 indicate that the direction of ground-water flow generally is the same during dry and wet seasons. Recharge to the shallow groundwater system occurs on the hillsides, and discharge occurs at hillside seeps and small tributaries where the water table seasonally intersects land surface. Evapotranspiration (where the water table is shallow), pumping of wells, and possibly discharge into alluvial deposits in the valley floor also contribute to discharge from the shallow flow system.

Water levels of selected wells are shown in appendix B. Water-level data used to construct the hydrographs were collected intermittently between June 1991 and October 1993. Because 1992 was the final year of a 6-year drought and because precipitation during the winter of 1993 was unusually high, the rise in water level listed in table 1 may represent the maximum natural fluctuation in the water table in recent history.

Hydraulic head in deep fractures beneath the valley floor is considerably higher than hydraulic head in the local shallow flow system. High hydraulic head causes deep wells in the valley floor (figs. 11 and 12) to flow at rates as high as 100 $\mathrm{gal} / \mathrm{min}$ (rates reported by drillers). Pressure-gage measurements for two deep flowing wells, G1 and G2 (figs. 11 and 12), show that hydraulic head varies seasonally between 4,220 and $4,240 \mathrm{ft}$ above sea level (recorded by well owners). (See wellnumbering diagram for description on format used for well numbers in text.) Hydraulic head in these wells are equivalent to water levels 140 and $160 \mathrm{ft}$ above land surface, respectively. Hydraulic head in wells that produce ground water from shallow fractures is below land surface.

Often, valleys are areas of ground-water discharge where hydraulic head increases with depth below the valley floor. In areas of high topographic relief, such as Wawona, head gradients beneath a valley can be strongly upward. The vertical gradient of hydraulic head, or head gradient, is the difference in hydraulic head divided by the distance between the points where hydraulic head is measured in a well. Vertical head gradients in the valley floor at Wawona are larger than expected for ground water flowing through uniformly fractured rocks in an area of high relief.

An extremely high head gradient was measured at TH2 in September 1992 just prior to in situ stress measurements. Hydraulic head differed by about $145 \mathrm{ft}$ in naturally occurring fractures at depths 223 and $255 \mathrm{ft}$ below land surface. The vertical-head gradient between the fractures is upward at about $4.5 \mathrm{ft} / \mathrm{ft}$. The high head gradient indicates that there is a barrier to ground-water flow between the deep and shallow fractures at TH2. High hydraulic head 
Table 1. Water-level altitudes and changes in water levels for shallow wells and wells producing water from shallow fractures in Wawona, Yosemite National Park, California, autumn 1992 and winter/spring 1993

[Water-level altitudes correspond to contours of hydraulic head in figures 11 and 12. State well No.: See well- and spring-numbering system on page VII. Depth of well in feet below land surface. Altitude of land surface in feet above sea level. Depth of well, altitude of land surface, and water-level altitude are rounded to nearest foot. ft; foot]

\begin{tabular}{|c|c|c|c|c|c|}
\hline \multirow{2}{*}{$\begin{array}{c}\text { State } \\
\text { well No. }\end{array}$} & \multirow{2}{*}{$\begin{array}{l}\text { Depth } \\
\text { of } \\
\text { well } \\
\text { (ft) }\end{array}$} & \multirow{2}{*}{$\begin{array}{c}\text { Altitude } \\
\text { of land } \\
\text { surface } \\
\text { (ft) }\end{array}$} & \multicolumn{2}{|c|}{$\begin{array}{l}\text { Water-level altitude } \\
\text { (ft) }\end{array}$} & \multirow{2}{*}{$\begin{array}{c}\text { Rise } \\
\text { in water } \\
\text { level } \\
\text { (ft) }\end{array}$} \\
\hline & & & $\begin{array}{c}\text { Autumn } \\
1992\end{array}$ & $\begin{array}{c}\text { Winter/spring } \\
1993\end{array}$ & \\
\hline $4 \mathrm{~S} / 21 \mathrm{E}-35 \mathrm{~B} 1$ & 90 & 4,218 & 4,178 & 4,195 & 17 \\
\hline $35 \mathrm{~B} 2$ & 138 & 4,151 & 4,128 & 4,142 & 14 \\
\hline $35 \mathrm{C} 1$ & 95 & 4,210 & 4,153 & 4,170 & 17 \\
\hline $35 \mathrm{C} 3$ & 13 & 4,173 & 4,129 & 4,144 & 15 \\
\hline $35 \mathrm{C} 8$ & 250 & 4,265 & 4,245 & 4,253 & 8 \\
\hline $35 \mathrm{C} 10$ & 51 & 4,156 & 4,139 & 4,151 & 12 \\
\hline $35 \mathrm{C} 11$ & 77 & 4,127 & 4,101 & 4,110 & 9 \\
\hline $35 \mathrm{C} 12$ & 106 & 4,148 & 4,112 & 4,124 & 12 \\
\hline 35D1 & 54 & 4,155 & 4,121 & 4,129 & 8 \\
\hline 35D5 & 34 & 4,134 & 4,131 & 4,133 & 2 \\
\hline 35D6 & 400 & 4,130 & 4,125 & 4,129 & 4 \\
\hline $35 \mathrm{E} 1$ & 250 & 4,047 & 4,040 & 4,045 & 5 \\
\hline $35 \mathrm{E} 2$ & 90 & 4,044 & 4,032 & 4,039 & 7 \\
\hline $35 \mathrm{E} 12$ & 200 & 4,160 & 4,117 & 4,127 & 10 \\
\hline $35 \mathrm{E} 13$ & 92 & 4,091 & 4,069 & 4,077 & 8 \\
\hline $35 \mathrm{E} 16$ & 133 & 4,042 & 4,032 & 4,038 & 6 \\
\hline $35 \mathrm{~F} 1$ & 71 & 4,085 & 4,069 & 4,074 & 5 \\
\hline $35 \mathrm{~F} 2$ & 60 & 4,046 & 4,036 & 4,042 & 6 \\
\hline $35 \mathrm{~F} 6$ & 45 & 4,108 & 4,085 & 4,094 & 9 \\
\hline $35 \mathrm{G} 6$ & 90 & 4,139 & 4,120 & 4,134 & 14 \\
\hline $35 \mathrm{G} 7$ & 74 & 4,131 & 4,114 & 4,126 & 12 \\
\hline $35 \mathrm{H} 5$ & 98 & 4,210 & 4,130 & 4,153 & 23 \\
\hline $35 \mathrm{H} 9$ & 62 & 4,123 & 4,099 & 4,103 & 4 \\
\hline $35 \mathrm{~L} 3$ & 127 & 4,143 & 4,082 & 4,092 & 10 \\
\hline $35 \mathrm{Ml}$ & 155 & 4,092 & 4,031 & 4,051 & 20 \\
\hline 35M5 & 17 & 4,012 & 3,999 & 4,004 & 5 \\
\hline $35 \mathrm{M} 6$ & 8 & 4,025 & 4,017 & 4,023 & 6 \\
\hline $35 \mathrm{M} 8$ & 100 & 4,034 & 4,011 & 4,026 & 15 \\
\hline $35 \mathrm{M} 9$ & 20 & 4,036 & 4,017 & 4,028 & 11 \\
\hline $35 \mathrm{P} 1$ & 68 & 4,210 & 4,170 & 4,183 & 13 \\
\hline $35 \mathrm{P} 2$ & 72 & 4,256 & 4,200 & 4,214 & 14 \\
\hline $35 \mathrm{P} 3$ & 160 & 4,129 & 4,092 & 4,106 & 14 \\
\hline $35 \mathrm{Q} 1$ & 209 & 4,375 & 4,302 & 4,315 & 13 \\
\hline $35 Q^{2}$ & 55 & 4,135 & 4,251 & 4,253 & 2 \\
\hline $5 \mathrm{~S} / 21 \mathrm{E}-2 \mathrm{H} 1$ & 6 & 4,135 & 4,133 & 4,135 & 2 \\
\hline
\end{tabular}

in fractures deeper than $400 \mathrm{ft}$ below land surface in wells G1, G2, G3, 36M1, and TH1 (fig. 11 and 12) indicates that vertical permeability may be similarly restricted throughout the valley.

A barrier to vertical flow would exist if deep, permeable fractures are hydraulically isolated (not interconnected). Permeable, steeply dipping fractures in the valley floor generally are oriented to the northwest. At shallow depths, subhorizontal frac- tures are permeable and hydraulically connect the permeable, steeply dipping fractures. At deeper depths, where hydraulic head is high, subhorizontal fractures are rare, annealed, or squeezed closed by the weight of overlying rock. If permeable, northwest-trending subvertical fractures have limited height, then the absence of horizontal fractures at depth would isolate them hydraulically. Because unweathered granitic rocks are relatively imperm- 


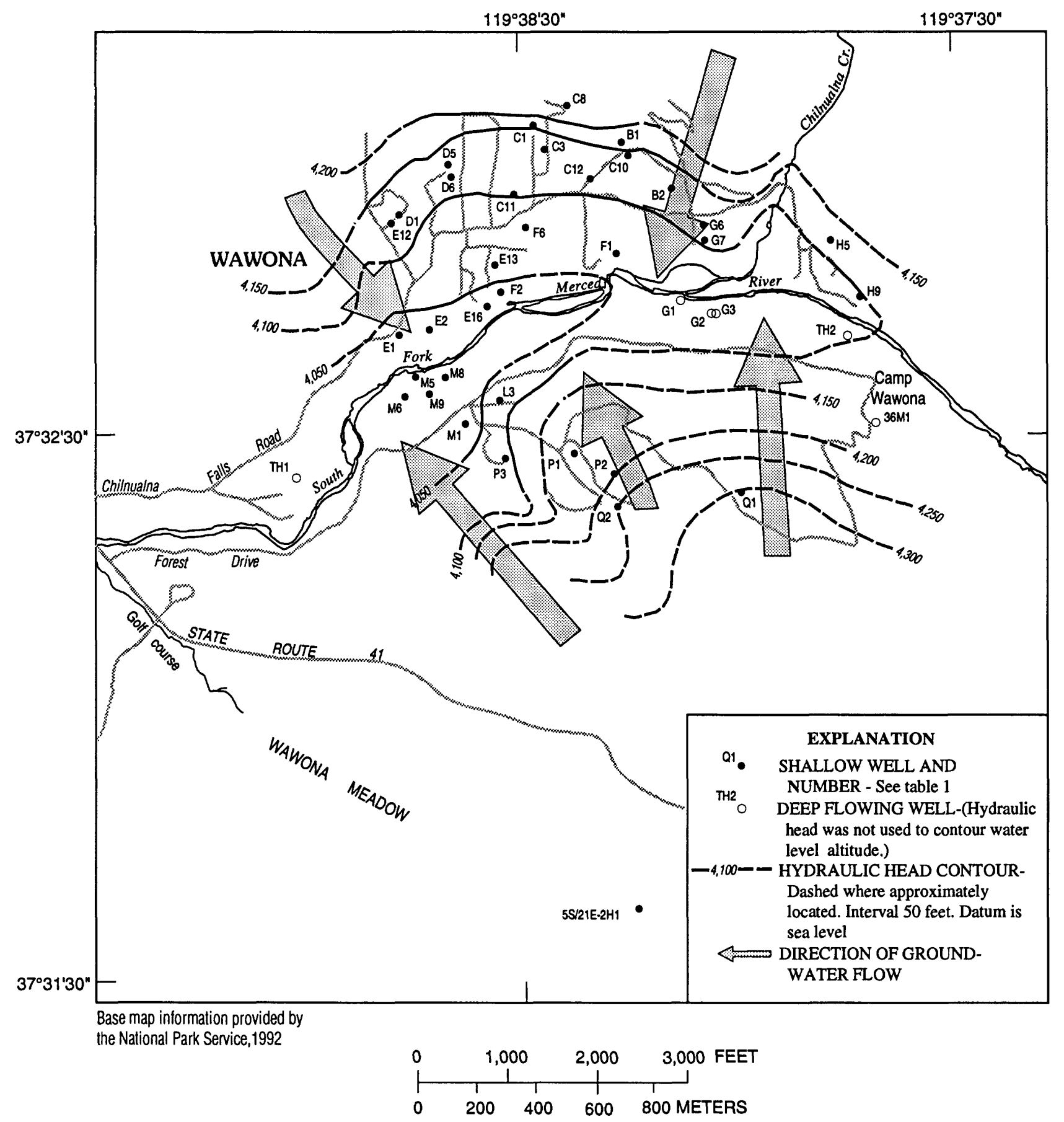

Figure 11. Hydraulic head in shallow wells and generalized direction of ground-water flow in the Wawona area, Yosemite National Park, California, autumn 1992.

eable unless fractured, high head gradients between shallow and deep fractures could exist. The isolation of deep, permeable fractures is consistent with the relation between in situ stress and fracture orientation used to conceptualize the ground-waterflow system at Wawona.

Hydraulic-head data indicate that a local ground-water-flow system has developed in the shallow, relatively well-connected fractures beneath the sides and floor of the South Fork Merced River valley. Ground water in this local flow system probably does not circulate deeper than about $250 \mathrm{ft}$ below the valley floor. Below this shallow flow system is deep, pressurized ground water that may be part of a slow-moving, regional ground-waterflow system or a body of less mobile ground water 


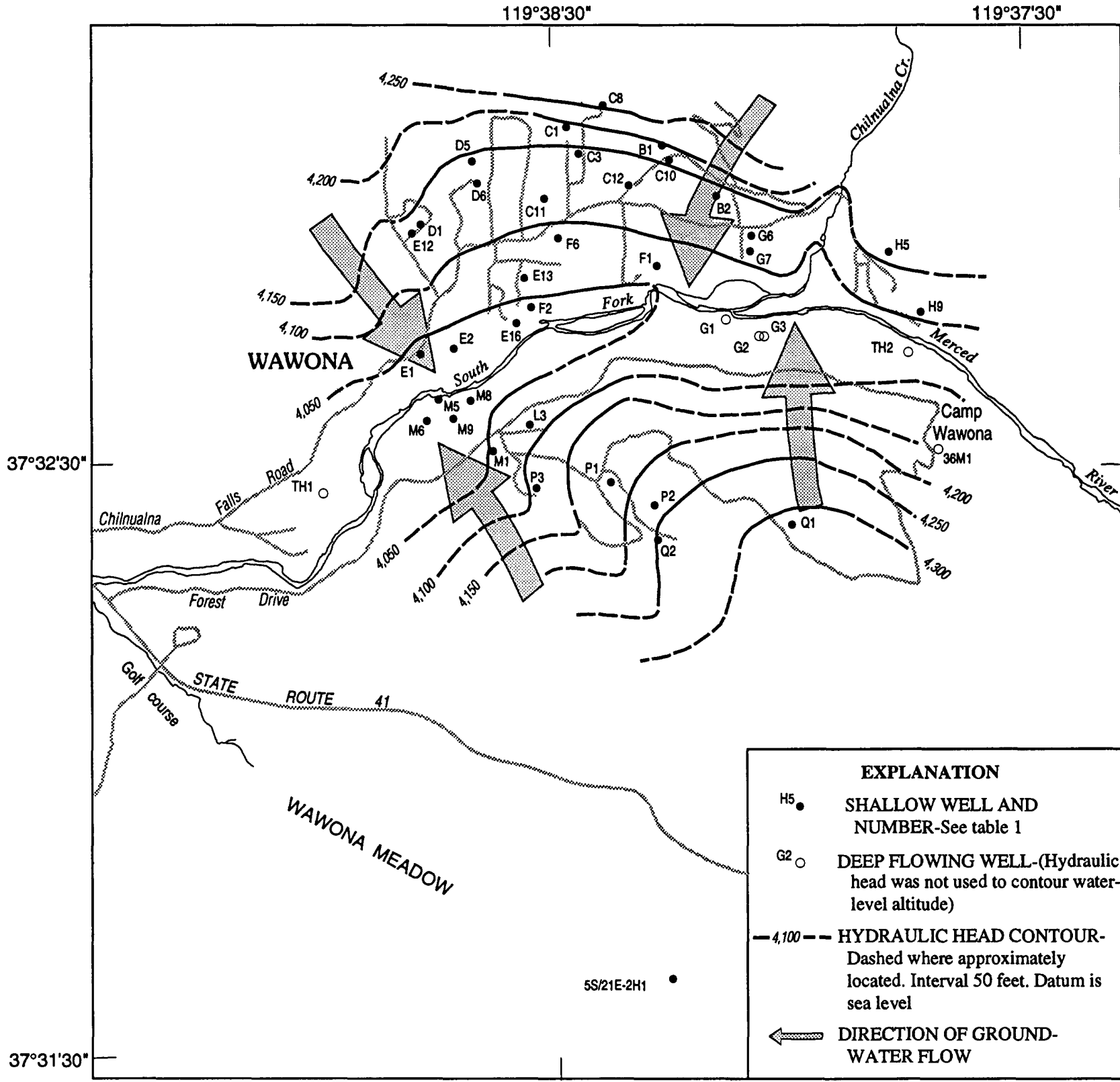

Base map information provided by the National Park Service, 1992

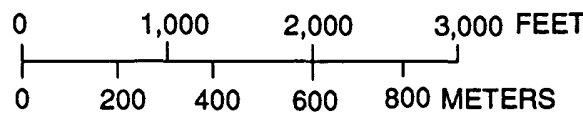

Figure 12. Hydraulic head in shallow wells and generalized direction of ground-water flow in the Wawona area, Yosemite National Park, California, winter/spring 1993.

trapped in hydraulically isolated fractures. In the absence of wells that can provide a pathway for ground water to bypass the natural flow system, very little flow is likely to occur between the shallow and deep flow systems.

Shallow wells in the hillsides adjacent to the South Fork Merced River can be conduits that allow ground water to flow between fractures in the local ground-water-flow system. Flow measurements made at well B2 indicate that ground water enters this well at a rate of $0.2 \mathrm{gal} / \mathrm{min}$ from a shallow fracture $40 \mathrm{ft}$ below land surface and then exits the well at a fracture $90 \mathrm{ft}$ below land surface (appendix A).

Downward flow in well B2 indicates that hydraulic head is higher in shallow fractures than in 
Table 2. Selected chemical data for ground water from wells at Wawona, Biledo Spring, and Biledo Meadow Forest, California, summer 1991 through autumn 1993

[Data from wells are listed in order of increasing concentrations of dissolved chloride to more readily show differences in page VII. See figure 4 for location of wells. Depth of well in feet below land surface. Altitude of land surface in feet above $\mathrm{S}$, well producing ground water from shallow fractures; SD, well producing ground water from shallow and deep fractures. bromide to dissolved chloride. TH1, test hole 1; TH2, test hole 2. do., ditto; <, actual value is less than value shown;

\begin{tabular}{|c|c|c|c|c|c|c|c|c|c|}
\hline \multicolumn{2}{|c|}{$\begin{array}{c}\text { State } \\
\text { well No., } \\
\text { test hole, } \\
\text { or spring }\end{array}$} & \multirow{2}{*}{$\begin{array}{c}\begin{array}{c}\text { Date } \\
\text { samp- } \\
\text { led }\end{array} \\
8-21-91\end{array}$} & \multirow{2}{*}{$\begin{array}{c}\begin{array}{c}\text { Samp- } \\
\text { ling } \\
\text { condi- } \\
\text { tion }\end{array} \\
\text { Pumped }\end{array}$} & \multirow[t]{2}{*}{$\begin{array}{l}\text { Produc- } \\
\text { ing } \\
\text { frac- } \\
\text { ture } \\
\text { depth } \\
\end{array}$} & \multirow[t]{2}{*}{$\begin{array}{c}\begin{array}{c}\text { Depth } \\
\text { of } \\
\text { well }\end{array} \\
68.3\end{array}$} & \multirow[t]{2}{*}{$\begin{array}{c}\begin{array}{c}\text { Alti- } \\
\text { tude } \\
\text { of land } \\
\text { surface } \\
\text { (ft) }\end{array} \\
4,210\end{array}$} & \multirow[t]{2}{*}{$\begin{array}{c}\begin{array}{c}\text { Speci- } \\
\text { fic } \\
\text { conduc- } \\
\text { tance } \\
(\mu \mathrm{S} / \mathrm{cm})\end{array} \\
64\end{array}$} & \multirow[t]{2}{*}{$\begin{array}{c}\begin{array}{c}\mathrm{pH} \\
\text { (stand- } \\
\text { ard } \\
\text { units) }\end{array} \\
6.1\end{array}$} & \multirow[t]{2}{*}{$\begin{array}{c}\begin{array}{c}\text { Cal- } \\
\text { cium, } \\
\text { dis- } \\
\text { solved } \\
(\mathrm{mg} / \mathrm{L})\end{array} \\
6.5\end{array}$} \\
\hline $4 \mathrm{~S} / 21 \mathrm{E}-$ & 35P1 & & & & & & & & \\
\hline & $35 Q 1$ & $8-19-91$ & do. & $S$ & 209.0 & 4,375 & 108 & 6.4 & 9.6 \\
\hline & $35 \mathrm{D} 6$ & 8-03-91 & do. & $S$ & 400.0 & 4,130 & 161 & 7.4 & 20 \\
\hline & $35 \mathrm{E} 1$ & $8-27-91$ & do. & $S$ & 250.0 & 4,047 & 94 & 6.5 & 9.5 \\
\hline & $35 \mathrm{C} 8$ & $8-31-91$ & do. & $S$ & 87.0 & 4,265 & 82 & 6.5 & 8.0 \\
\hline & $35 \mathrm{H} 3$ & $8-30-91$ & do. & $S$ & 175.0 & 4,176 & 100 & 6.5 & 10 \\
\hline & 35D9 & $8-30-91$ & do. & $S$ & 200.0 & 4,117 & 147 & 6.6 & 16 \\
\hline & $35 \mathrm{P} 2$ & $8-21-91$ & do. & $S$ & 72.1 & 4,245 & 71 & 6.3 & 6.9 \\
\hline & $35 \mathrm{C} 4$ & $8-26-91$ & do. & $S$ & 60.0 & 4,199 & 117 & 6.8 & 12 \\
\hline & $35 \mathrm{C} 2$ & $8-25-91$ & do. & $S$ & -- & 4,125 & 126 & 6.8 & 15 \\
\hline & $35 \mathrm{~B} 1$ & $8-26-91$ & do. & $S$ & 90.0 & 4,218 & 95 & 6.6 & 9.8 \\
\hline & $35 \mathrm{H} 1$ & $8-31-91$ & do. & $S$ & 114.0 & 4,195 & 157 & 6.5 & 20 \\
\hline & $35 \mathrm{C} 5$ & $8-26-91$ & do. & $S$ & 107.0 & 4,136 & 106 & 6.6 & 10 \\
\hline & $35 \mathrm{Cl}$ & $8-25-91$ & do. & $S$ & 95.0 & 4,210 & 109 & 6.7 & 12 \\
\hline & $35 \mathrm{E} 12$ & $8-28-91$ & do. & $S$ & 200.0 & 4,160 & 102 & 6.2 & 10 \\
\hline & $35 \mathrm{H} 2$ & $9-07-91$ & do. & $S$ & 60.0 & 4,178 & 100 & 6.4 & 11 \\
\hline & $35 \mathrm{E} 8$ & $8-29-91$ & do. & $S$ & 260.0 & 4,161 & 151 & 6.6 & 18 \\
\hline & $35 \mathrm{D} 5$ & 8-30-91 & do. & $S$ & 34.0 & 4,134 & 107 & 6.4 & 11 \\
\hline & $35 \mathrm{H} 9$ & $9-07-91$ & do. & $S$ & 62.4 & 4,185 & 150 & 6.7 & 17 \\
\hline & $35 \mathrm{E} 3$ & $8-27-91$ & do. & $S$ & 300.0 & 4,062 & 120 & 6.6 & 14 \\
\hline & 35D1 & $8-28-91$ & do. & $S$ & 54.1 & 4,155 & 107 & 6.3 & 11 \\
\hline & $35 \mathrm{C} 13$ & $8-27-91$ & do. & $S$ & 85.0 & 4,151 & 122 & 6.6 & 12 \\
\hline & $35 \mathrm{C} 3$ & 8-26-91 & do. & $S$ & 142.9 & 4,173 & 122 & 6.8 & 14 \\
\hline & $35 \mathrm{~L} 2$ & $8-22-91$ & do. & $S$ & 97.0 & 4,133 & 125 & 6.8 & 14 \\
\hline & $35 \mathrm{~F} 7$ & $8-17-91$ & do. & $S$ & 94.0 & 4,118 & 98 & 6.6 & 10 \\
\hline & $35 \mathrm{P} 3$ & $8-25-91$ & do. & $S$ & 160.0 & 4,129 & 123 & 6.9 & 15 \\
\hline & $35 \mathrm{~L} 1$ & $8-22-91$ & do. & $S$ & 86.5 & 4,124 & 114 & 6.6 & 13 \\
\hline & $35 \mathrm{~B} 2$ & $8-25-91$ & do. & $S^{1}$ & 138.0 & 4,151 & 137 & 6.5 & 14 \\
\hline & $35 \mathrm{M} 2$ & $8-23-91$ & do. & $S$ & 48.8 & 4,037 & 116 & 6.6 & 12 \\
\hline
\end{tabular}

deeper fractures. Therefore, water-level measurements for well B2 are an underestimate of hydraulic head in the shallow fracture and an overestimate of hydraulic head in the deeper fracture. Because many of the shallow wells may be similarly affected, the altitudes of the water table in these wells also may be underestimated.

Well R1, which is located on top of a low ridge separating the South Fork Merced River valley from the Wawona meadow, allows shallow ground water in the local flow system to flow down the well and mix with much deeper ground water. Flowmeter logs for well R1 indicate that ground water, which is low in dissolved solids (as shown by the fluidresistivity $\log$ in appendix $A$ ), enters this well at a rate of about $0.3 \mathrm{gal} / \mathrm{min}$ at shallow fractures about
80 and $115 \mathrm{ft}$ below land surface and exits the well about $880 \mathrm{ft}$ below land surface (appendix A). Water-level measurements in this well also are an underestimate of hydraulic head in the fractures 80 and $115 \mathrm{ft}$ below land surface and an overestimate of hydraulic head in the fracture at $880 \mathrm{ft}$ below land surface. Data from the deep wells in the hillsides of the South Fork Merced River valley were not used to contour hydraulic head in the local shallow flow system because water levels in these wells are a composite of head in the shallow and deep ground-water-flow systems (figs. 11 and 12).

Ground water in deep wells in the valley floor flows upward from deep fractures and out of the wells where hydraulic head is lower at shallower fractures and at land surface. Borehole geophysical 
spring 1 and from stream sampling sites in the Wawona area of Yosemite National Park and the Sierra National

composition among shallow, deep, and mixed ground waters. State well No.: See well- and spring-numbering system on sea level, rounded to the nearest foot. Producing fracture depth: D, well producing ground water only from deep fractures; $\mathrm{ft}$, foot; $\mu \mathrm{S} / \mathrm{cm}$, microsiemens per centimeter at 25 degrees Celsius; $\mathrm{mg} / \mathrm{L}$, milligram per liter; $\mathrm{Br} / \mathrm{Cl}$, ratio of dissolved -.. no data]

\begin{tabular}{|c|c|c|c|c|c|c|c|c|c|}
\hline $\begin{array}{l}\text { Magne- } \\
\text { sium, } \\
\text { dis- } \\
\text { solved } \\
(\mathrm{mg} / \mathrm{L})\end{array}$ & $\begin{array}{c}\text { Sod- } \\
\text { ium, } \\
\text { dis- } \\
\text { solved } \\
(\mathrm{mg} / \mathrm{L})\end{array}$ & $\begin{array}{l}\text { Potas- } \\
\text { ium, } \\
\text { dis- } \\
\text { solved } \\
(\mathrm{mg} / \mathrm{L})\end{array}$ & $\begin{array}{c}\text { Alka- } \\
\text { linity } \\
\text { (mg/L } \\
\text { as } \\
\left.\mathrm{CaCO}_{3}\right)\end{array}$ & $\begin{array}{c}\text { Cal- } \\
\text { cite } \\
\text { satura- } \\
\text { tion } \\
\text { index }\end{array}$ & $\begin{array}{c}\text { Sul- } \\
\text { fate, } \\
\text { dis- } \\
\text { solved } \\
(\mathrm{mg} / \mathrm{L})\end{array}$ & $\begin{array}{l}\text { Chlor- } \\
\text { ide, } \\
\text { dis- } \\
\text { solved } \\
(\mathrm{mg} / \mathrm{L})\end{array}$ & $\begin{array}{c}\text { Fluo- } \\
\text { ride, } \\
\text { dis- } \\
\text { solved } \\
(\mathrm{mg} / \mathrm{L})\end{array}$ & $\begin{array}{c}\text { Bro- } \\
\text { mide, } \\
\text { dis- } \\
\text { solved } \\
(\mathrm{mg} / \mathrm{L})\end{array}$ & $\begin{array}{l}\text { Ratio } \\
(\mathrm{Br} / \mathrm{Cl})\end{array}$ \\
\hline 0.82 & 6.5 & 1.0 & 34 & -2.93 & 0.2 & $<0.01$ & $<0.10$ & $<0.01$ & -- \\
\hline 1.9 & 10 & 2.2 & 57 & -2.34 & .3 & .20 & .10 & $<.01$ & .- \\
\hline 3.9 & 12 & 1.8 & 91 & -.80 & .5 & .40 & $<0.10$ & $<.01$ & -- \\
\hline 1.5 & 9.3 & 1.7 & 51 & -2.25 & .2 & .50 & $<0.10$ & $<.01$ & -- \\
\hline 1.1 & 8.6 & 1.3 & 44 & -2.35 & .3 & .50 & $<0.10$ & $<.01$ & -- \\
\hline 1.8 & 9.1 & 1.9 & 54 & -2.20 & .2 & .50 & $<0.10$ & $<.01$ & -- \\
\hline 3.4 & 12 & 1.7 & 68 & -1.83 & .5 & .50 & $<0.10$ & $<.01$ & -- \\
\hline .83 & 7.1 & .90 & 40 & -2.66 & .2 & .50 & $<0.10$ & $<.01$ & -- \\
\hline 1.4 & 9.6 & 1.4 & 60 & -1.77 & .6 & .60 & $<0.10$ & $<.01$ & -- \\
\hline 1.7 & 10 & .90 & 65 & -1.65 & .5 & .60 & $<0.10$ & $<.01$ & -- \\
\hline 1.7 & 9.0 & 1.6 & 53 & -2.10 & .3 & .60 & $<0.10$ & $<.01$ & -- \\
\hline 3.5 & 9.6 & 1.7 & 85 & -1.73 & .5 & .60 & $<0.10$ & $<.01$ & -- \\
\hline 1.0 & 11 & .90 & 51 & -2.14 & .3 & .70 & $<0.10$ & $<.01$ & -- \\
\hline 1.1 & 10 & 1.0 & 56 & -1.90 & .6 & .70 & $<0.10$ & $<.01$ & -- \\
\hline 1.8 & 9.4 & 1.6 & 53 & -2.53 & .3 & .70 & $<0.10$ & $<.01$ & -.- \\
\hline 2.6 & 9.2 & 2.1 & 54 & -2.28 & .3 & .70 & $<0.10$ & $<.01$ & -- \\
\hline 3.8 & 11 & 1.8 & 83 & -1.69 & .3 & .80 & $<0.10$ & $<.01$ & -. \\
\hline 2.3 & 8.9 & 1.4 & 58 & -2.26 & .2 & .80 & $<0.10$ & $<.01$ & -- \\
\hline 3.4 & 12 & 2.1 & 81 & -1.43 & .7 & .80 & 0.10 & $<.01$ & -- \\
\hline 1.4 & 9.3 & 2.1 & 64 & -1.90 & .8 & 1.0 & $<0.10$ & .01 & 0.01000 \\
\hline 2.2 & 9.5 & 1.6 & 55 & -2.37 & .3 & 1.0 & $<0.10$ & $<.01$ & -- \\
\hline 1.6 & 10 & 1.4 & 61 & -1.98 & .4 & 1.2 & $<0.10$ & $<.01$ & -- \\
\hline 1.6 & 10 & .90 & 65 & -1.74 & .8 & 1.2 & 0.10 & $<.01$ & -- \\
\hline 1.8 & 8.2 & 1.8 & 63 & -1.76 & .3 & 1.3 & $<0.10$ & $<.01$ & -- \\
\hline 1.5 & 10 & .90 & 46 & -2.13 & .3 & 1.6 & $<0.10$ & $<.01$ & -- \\
\hline 2.4 & 8.2 & 2.2 & 66 & -1.59 & .3 & 1.6 & $<0.10$ & -- & -- \\
\hline 1.9 & 7.8 & 2.8 & 60 & -1.99 & .3 & 1.7 & $<0.10$ & $<.01$ & -- \\
\hline 3.2 & 10 & 2.1 & 70 & -1.59 & .8 & 2.2 & 0.10 & $<.01$ & -- \\
\hline 2.0 & 9.8 & 1.4 & 55 & -2.05 & 1.1 & 4.0 & $<0.10$ & .01 & .00250 \\
\hline
\end{tabular}

logs for TH1 and TH2 and well 36M1 (appendix A) illustrate the upward flow of deep ground water. Drillers' logs indicate that the same conditions exist in wells G1, G2, and G3. Data on these deep wells were not used to contour hydraulic head in the deep fractures because equipment was not available to isolate fractures for measurement of hydraulic head because some wells were inaccessible and because so few deep wells have been drilled in the Wawona area.

\section{Major lons}

Ground water is chemically segregated vertically. Ground water flowing through shallow fractured rocks is dilute. Ground water under high hydraulic head in deep fractures is more mineralized. Specific conductance, a measure of the dissolved mineral content of water, is much lower in water from shallow wells. In Wawona, specific conductance ranges from 64 to $207 \mu \mathrm{S} / \mathrm{cm}$ (microsiemens per centimeter) in wells that are less than about $300 \mathrm{ft}$ deep and in deeper wells that receive ground water primarily from shallow fractures (type $S$, table 2). The deeper flowing wells in the valley floor intersect fractures that contain ground water with a specific conductance that ranges from 369 to $2,350 \mu \mathrm{S} / \mathrm{cm}$ (type D, table 2). Data in table 2 are listed in order of increasing concentrations of dissolved chloride so that differences in composition among shallow, deep, and mixed ground waters are more obvious. 
Table 2. Selected chemical data for ground water from wells at Wawona, Biledo Spring, and Biledo Meadow National Forest, California, summer 1991 through autumn 1993--Continued

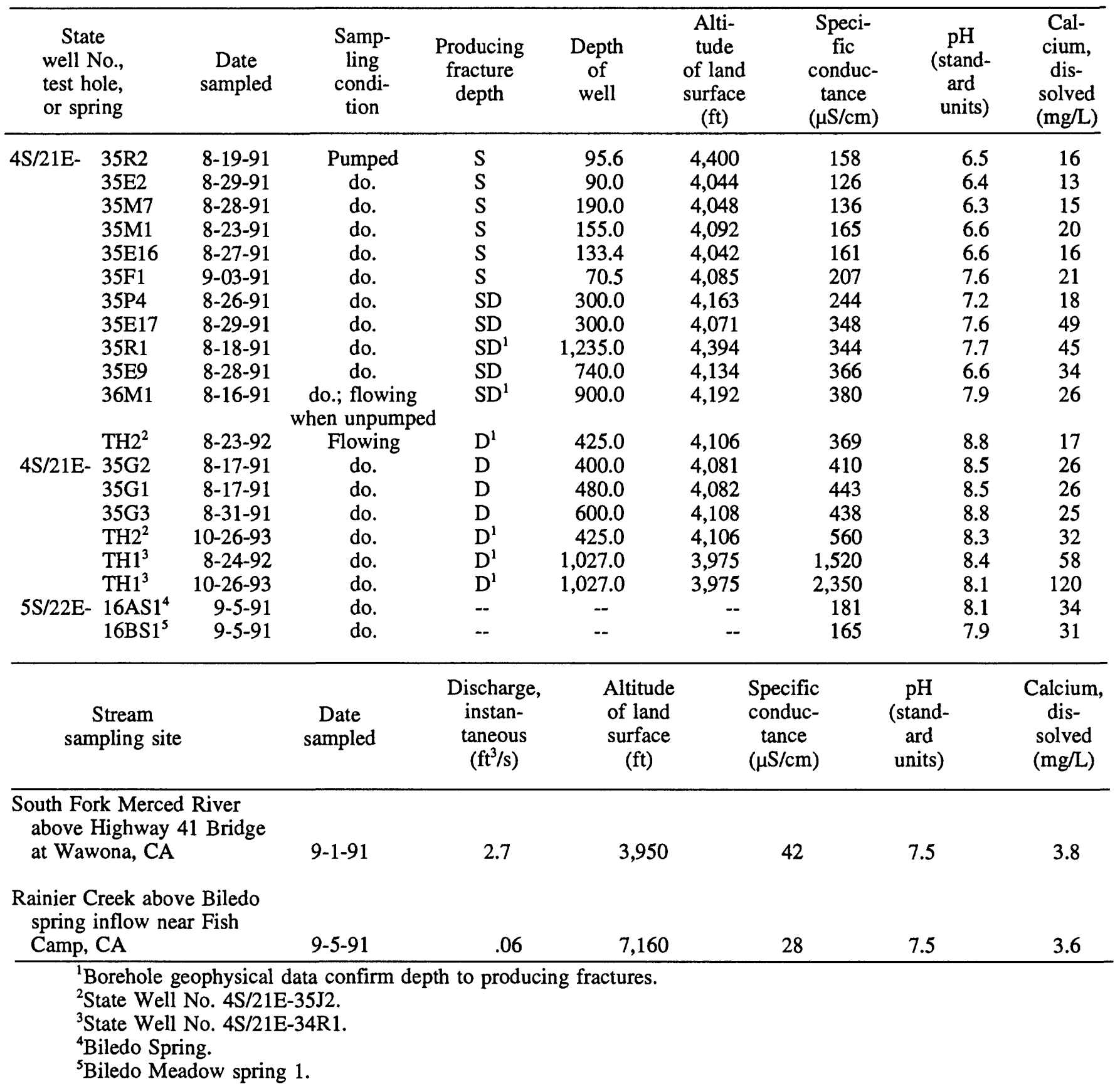

The ionic composition of ground water also varies with depth. The relative proportion of major cations and anions in each water sample is shown on the trilinear diagram as a percentage of the total cationic (positively charged ions) or anionic (negatively charged ions) content measured in milliequivalent per liter (meq/L) (fig. 13). Data collected from wells, the high altitude springs in the Biledo Meadow area, and stream-sampling sites on the South Fork Merced River and on Rainier Creek are shown in figure 13 and listed in table 2. Two samples were collected from each of the test holes (TH1 and TH2)-once when the test holes were drilled in late August 1992 and a second time after long-term flow tests when specific conductance of discharging water had increased at each test hole.

Shallow wells and wells that receive groundwater inflow primarily from shallow fractures (type $\mathrm{S}$, table 2) produce ground water classified as a 
spring 1 and from stream sampling sites in the Wawona area of Yosemite National Park and the Sierra

\begin{tabular}{|c|c|c|c|c|c|c|c|c|c|}
\hline $\begin{array}{l}\text { Magne- } \\
\text { sium, } \\
\text { dis- } \\
\text { solved } \\
(\mathrm{mg} / \mathrm{L}) \\
\end{array}$ & $\begin{array}{c}\text { Sod- } \\
\text { ium, } \\
\text { dis- } \\
\text { solved } \\
(\mathrm{mg} / \mathrm{L})\end{array}$ & $\begin{array}{l}\text { Potas- } \\
\text { ium, } \\
\text { dis- } \\
\text { solved } \\
(\mathrm{mg} / \mathrm{L})\end{array}$ & $\begin{array}{c}\text { Alka- } \\
\text { linity } \\
(\mathrm{mg} / \mathrm{L} \\
\mathrm{as} \\
\left.\mathrm{CaCO}_{3}\right)\end{array}$ & $\begin{array}{c}\text { Cal- } \\
\text { cite } \\
\text { satura- } \\
\text { tion } \\
\text { index }\end{array}$ & $\begin{array}{c}\text { Sul- } \\
\text { fate, } \\
\text { dis- } \\
\text { solved } \\
(\mathrm{mg} / \mathrm{L}) \\
\end{array}$ & $\begin{array}{l}\text { Chlor- } \\
\text { ide, } \\
\text { dis- } \\
\text { solved } \\
(\mathrm{mg} / \mathrm{L})\end{array}$ & $\begin{array}{c}\text { Fluo- } \\
\text { ride, } \\
\text { dis- } \\
\text { solved } \\
(\mathrm{mg} / \mathrm{L})\end{array}$ & $\begin{array}{c}\text { Bro- } \\
\text { mide, } \\
\text { dis- } \\
\text { solved } \\
(\mathrm{mg} / \mathrm{L})\end{array}$ & $\begin{array}{c}\text { Ratio } \\
(\mathrm{Br} / \mathrm{Cl})\end{array}$ \\
\hline 2.1 & 11 & 2.2 & 60 & -2.00 & $<0.10$ & 5.7 & $<0.10$ & 0.03 & 0.00526 \\
\hline 2.4 & 12 & 1.7 & 58 & -2.17 & .30 & 6.5 & $<.10$ & .01 & .00154 \\
\hline 2.0 & 10 & 2.2 & 56 & -2.26 & .80 & 8.7 & $<.10$ & .02 & .00230 \\
\hline 2.6 & 11 & 2.5 & 71 & -1.74 & .50 & 9.5 & $<.10$ & .02 & .00211 \\
\hline 2.9 & 13 & 2.2 & 70 & -1.81 & .50 & 9.7 & $<.10$ & .02 & .00206 \\
\hline 3.0 & 16 & 1.8 & 80 & -.66 & 1.2 & 17 & .30 & .04 & .00235 \\
\hline 1.3 & 32 & 1.8 & 83 & -1.13 & 2.1 & 27 & .30 & .04 & .00148 \\
\hline 6.0 & 16 & 1.8 & 115 & -.17 & 1.2 & 36 & $<.10$ & .07 & .00194 \\
\hline 4.4 & 24 & .90 & 124 & -.07 & 3.0 & 40 & .30 & .06 & .00150 \\
\hline 6.3 & 16 & 2.8 & 77 & -1.49 & $<.10$ & 68 & .10 & .01 & .00015 \\
\hline .74 & 55 & .60 & 77 & -.25 & 5.2 & 71 & .90 & .14 & .00197 \\
\hline .04 & 53 & .40 & 25 & .04 & 6.6 & 97 & 1.4 & .13 & .00134 \\
\hline .19 & 56 & .80 & 35 & -.07 & 5.6 & 100 & 1.7 & .13 & .00130 \\
\hline .19 & 57 & .80 & 34 & -.08 & 5.7 & 100 & 1.7 & .13 & .00130 \\
\hline .20 & 58 & .70 & 35 & .34 & 4.5 & 110 & 1.5 & .17 & .00154 \\
\hline .08 & 71 & .50 & 23 & -.37 & 6.2 & 150 & 1.3 & .18 & .00120 \\
\hline .35 & 250 & 1.1 & 29 & -.37 & 4.0 & 480 & 2.2 & .57 & .00119 \\
\hline .71 & 330 & 1.5 & 21 & -.17 & 5.6 & 750 & 1.9 & .73 & .00097 \\
\hline 3.3 & 1.5 & .80 & 100 & .03 & 1.4 & $<.10$ & $<.10$ & $<.10$ & -- \\
\hline 2.8 & 2.9 & .90 & 93 & -.21 & 2.2 & .20 & $<.10$ & $<.10$ & -- \\
\hline $\begin{array}{l}\text { Magne- } \\
\text { sium, } \\
\text { dis- } \\
\text { solved } \\
(\mathrm{mg} / \mathrm{L}) \\
\end{array}$ & $\begin{array}{c}\text { Sod- } \\
\text { ium, } \\
\text { dis- } \\
\text { solved } \\
(\mathrm{mg} / \mathrm{L})\end{array}$ & $\begin{array}{l}\text { Potas- } \\
\text { ium, } \\
\text { dis- } \\
\text { solved } \\
(\mathrm{mg} / \mathrm{L}) \\
\end{array}$ & $\begin{array}{c}\text { Alka- } \\
\text { linity } \\
(\mathrm{mg} / \mathrm{L} \\
\text { as } \\
\left.\mathrm{CaCO}_{3}\right)\end{array}$ & $\begin{array}{c}\text { Cal- } \\
\text { cite } \\
\text { satura- } \\
\text { tion } \\
\text { index }\end{array}$ & $\begin{array}{c}\text { Sul- } \\
\text { fate, } \\
\text { dis- } \\
\text { solved } \\
(\mathrm{mg} / \mathrm{L})\end{array}$ & $\begin{array}{l}\text { Chlor- } \\
\text { ide, } \\
\text { dis- } \\
\text { solved } \\
(\mathrm{mg} / \mathrm{L})\end{array}$ & $\begin{array}{l}\text { Fluo- } \\
\text { ride, } \\
\text { dis- } \\
\text { solved } \\
(\mathrm{mg} / \mathrm{L}) \\
\end{array}$ & $\begin{array}{c}\text { Bro- } \\
\text { mide, } \\
\text { dis- } \\
\text { solved } \\
(\mathrm{mg} / \mathrm{L})\end{array}$ & $\begin{array}{l}\text { Ratio } \\
(\mathrm{Br} / \mathrm{Cl})\end{array}$ \\
\hline 0.51 & 4.0 & 0.80 & 18 & -- & 1.1 & 2.8 & $<0.10$ & $<0.10$ & -- \\
\hline .78 & 1.5 & .50 & 15 & -- & .40 & $<.10$ & $<.10$ & $<.10$ & -- \\
\hline
\end{tabular}

calcium bicarbonate or calcium sodium bicarbonate water type. This classification is based on the dominant cations and anions in the water. The cationic composition of shallow ground water ranges between 45 to 60 percent calcium and between 25 and 45 percent sodium (fig. 13). The anionic composition of shallow ground water is about 90 percent bicarbonate. Dissolved solids in water moving through and chemically reacting with granitic rocks of the Sierra Nevada are expected to be primarily calcium, sodium, and bicarbonate. Ground water charged with atmospheric carbon dioxide in infiltrating precipitation and with carbon dioxide from microbial degradation of organic matter in soils forms weakly acidic solutions.
These weak acidic solutions chemically weather granitic rocks by reacting with silicate minerals (primarily plagioclase, feldspar, amphibole, hornblende, and biotite) and secondary carbonate minerals (primarily calcite). The cationic composition of shallow ground water in granitic rocks commonly is dependent on mineral dissolution, precipitation of clay and other secondary minerals, and cation exchange with secondary clay minerals (Feth and others, 1964; Garrels, 1967; Waber and Nordstrom, 1993).

Cation concentrations in ground water from deep flowing wells (type $\mathrm{D}$, table 2) are dominated by dissolved sodium and chloride (fig. 13). The cationic content of ground water from these wells is 


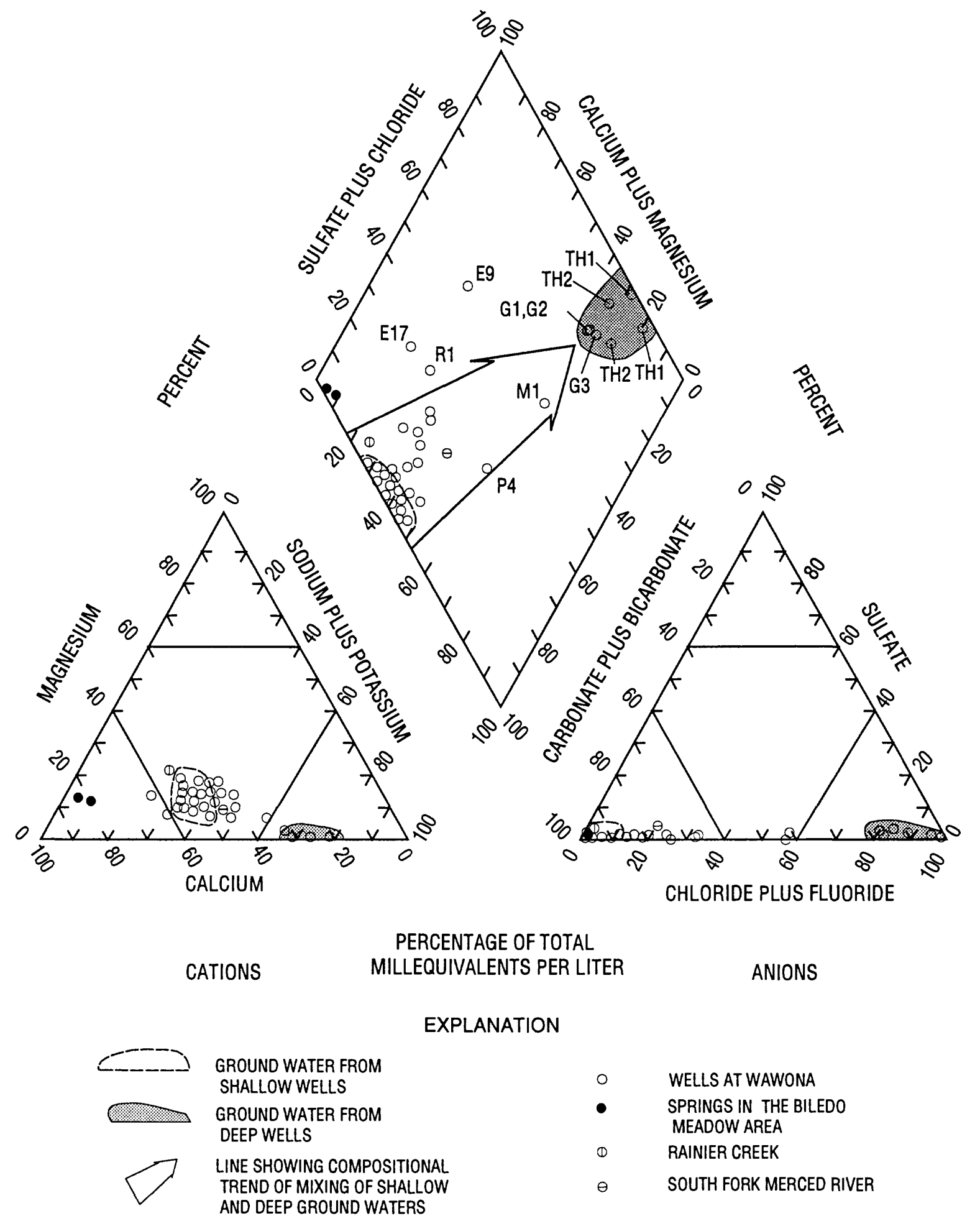

Figure 13. Chemical composition of water samples from wells, springs, and streams in the Wawona area, Yosemite National Park, California. 
between 65 and 80 percent sodium and between 20 and 35 percent calcium. The anionic content of ground water from these wells is at least 80 percent chloride.

If deep ground water evolved from a composition similar to that of shallow ground water in the South Fork Merced River valley, low alkalinity in samples from deep flowing wells might indicate that calcite has precipitated from solution. The calcite saturation index is slightly above zero for some samples from flowing wells and slightly below zero for other samples from flowing wells (table 2), indicating that deep ground water is saturated or nearly saturated with respect to calcite. Calcite is not obvious in well cuttings or at outcrops, but electron microprobe analysis showed finely disseminated veinlets of calcite in well cuttings from annealed fractures and adjacent alteration zones (Teresa Rogers, California State University, Sacramento, written commun., 1994).

Alternatively, if deep ground water is recharged at high altitudes where soil is thin or absent, low alkalinity might result because of a lack of microbially produced carbon dioxide. Silicate weathering reactions that produce higher alkalinity concentrations, similar to the concentrations in samples from the shallow wells (table 2), require more dissolved carbon dioxide than can be obtained from atmospheric partial pressures of carbon dioxide (Garrels, 1967).

The anionic composition of ground water from the deep flowing wells is not representative of chemical weathering of granitic rocks. Chloride, typically a conservative constituent in ground water, is not expected to participate in mineral dissolution and precipitation in granitic rocks. The plot for anions (fig. 13) shows a trend in the proportion of chloride dissolved in ground water, which is less than 10 percent of the total anionic content in the shallow wells to more than 80 percent in the deep flowing wells. Most samples with an intermediate chloride content can be explained by the mixing of shallow bicarbonate and deep chloride waters. This trend is not as clearly defined on the combined ion part of the trilinear diagram.

Samples from two wells (E17 and E9) plot noticeably off a mixing line between shallow and deep ground water (fig. 13). The cationic content of these two samples is dominated by calcium rather than sodium. The cationic content of other samples in which the anion percentage of chloride is intermediate between that of deep and shallow ground waters is dominated by sodium. It is unclear why the cationic content of these two samples is dominated by calcium. Geophysical logs, mineralogical samples, data on the variation of groundwater chemistry with depth in fractures contributing ground water, and information on possible chemical treatment to control iron bacteria or other problems are not available for these two wells.

During pumping, samples of discharge water from some wells intersecting both shallow and deep fractures exhibited large changes in specific conductance, temperature, $\mathrm{pH}$, and dissolved oxygen concentrations. The chemical composition of water from these wells varied, depending on the proportion of ground water from the shallow and deep fractures at the time a well was sampled. Data from the borehole geophysical logs verified that some wells produce dilute water from shallow fractures and more mineralized water from deep fractures (table 2). If the conceptual model of the aquifer in the South Fork Merced River valley is correct and if the deep, mineralized ground water is hydraulically separated from shallower, more dilute ground water, little mixing of shallow and deep waters occurs naturally. Most samples with a chloride content intermediate between that of shallow and deep ground water probably resulted from mixing shallow and deep ground water through wells that intersect shallow and deep fractures. In the absence of wells, little mixing probably would have occurred.

The source of chloride and increased mineral content of deep ground water is not known. Previous studies indicate that saline ground water in the granitic rocks of the foothills of the central Sierra Nevada is connate marine water that either has migrated upward along faults from subducted marine sediments (Mack and Ferrell, 1979) or has been squeezed from metamorphosed marine sediments and then has been greatly diluted with meteoric water (Mack and Schmidt, 1981; Mack and LeTourneau, 1982).

Fluid inclusions in minerals that form granitic rocks and in the igneous dikes and hydrothermal veins within the granitic rocks are another possible source of chloride and related cations in deep ground water at Wawona. Inclusion fluids are often highly saline (Roedder, 1984). Saline inclusion fluids could mix with ground water where rocks have been fractured either tectonically or by stressrelief processes when confining overburden pressure is removed by erosion. A chemical composition similar to the deep ground water at Wawona could result if saline fluid leaked slowly from inclusions to meteorically derived ground water for an extended period of time. It is plausible that stagnant bodies of ground water trapped in deep, dead-end fractures or ground water that moves slowly through a regional ground-water-flow system from high altitude recharge areas could evolve chemically in this manner. Fluid inclusions were shown to be a probable source of salinity in deep ground water in granitic rocks at Stripa, Sweden (Nordstrom and others, 1989a; 1989b). 


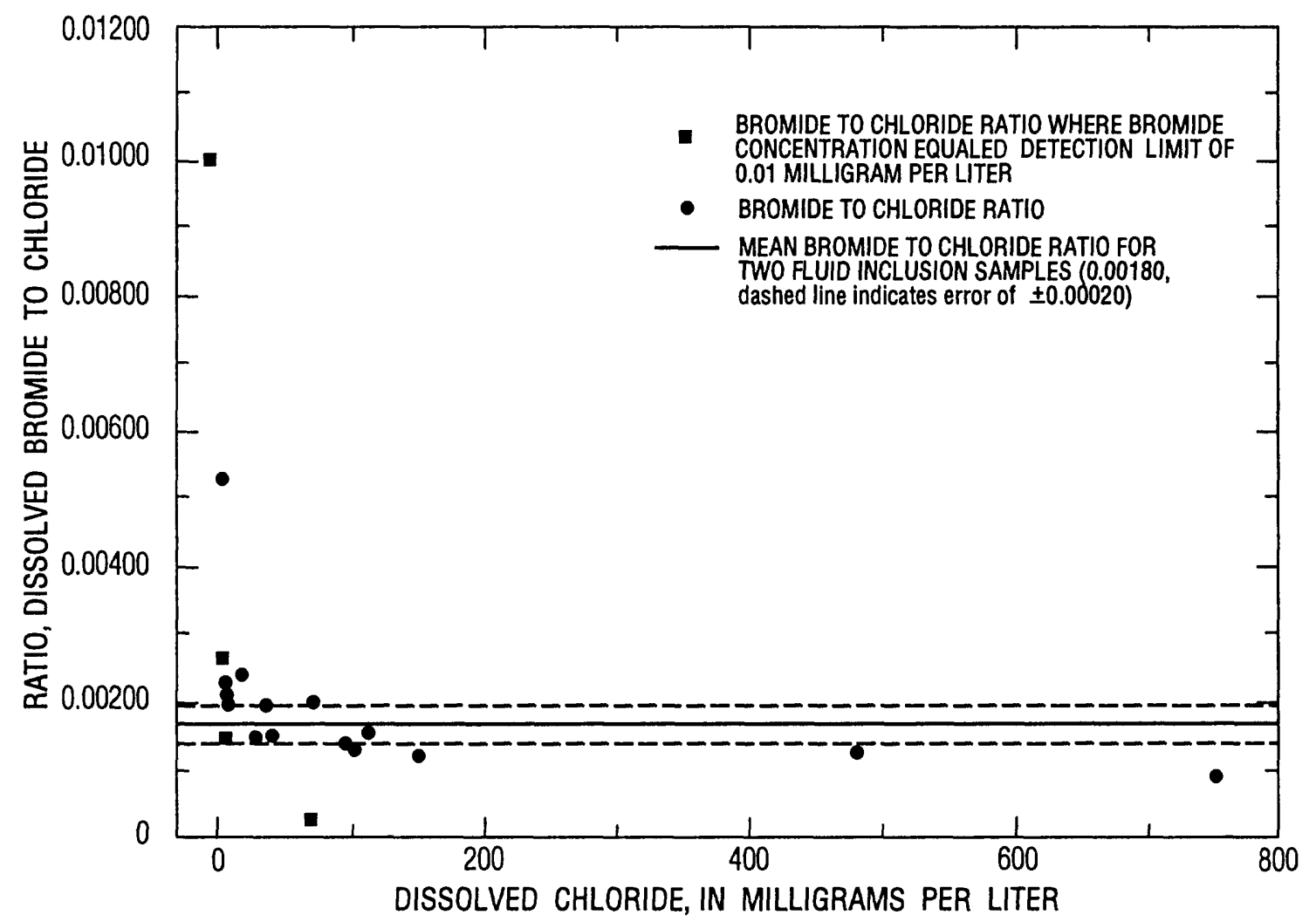

Figure 14. Bromide to chloride ratio as a function of chloride concentration in ground water and mean bromide to chloride ratio for two fluid-inclusion samples from granitic quartz in the Wawona area, Yosemite National Park, California.

Mass balance calculations needed to study the genesis of deep ground water at Wawona could not be done because no data were available to estimate the salinity or volume of inclusion fluids in the granitic rocks. However, the similarity of the ratio of dissolved bromide to chloride $(\mathrm{Br} / \mathrm{C} 1)$ in ground water at Wawona to the $\mathrm{Br} / \mathrm{C} 1$ ratio of two fluidinclusion samples from the granitic rocks indicates that fluid inclusions could be a source of the dissolved chloride.

The $\mathrm{Br} / \mathrm{Cl}$ ratios in ground water sampled at Wawona are relatively constant (a mean of about 0.0018 ) and are independent of the chloride concentrations (fig. 14). The exceptions were two values where the concentration of bromide was at the detection limit of the analytical technique (0.01000) (table 2, fig. 14). The majority of the samples for which a $\mathrm{Br} / \mathrm{C} 1$ ratio could be computed were from wells that produce some ground water from the deep fractures (SD and D, table 2). Because ground water in shallow fractures is dilute, the $\mathrm{Br} / \mathrm{C} 1$ ratio of the SD samples probably represents the value of the deeper, more saline ground water.

The $\mathrm{Br} / \mathrm{Cl}$ ratios of fluid inclusion leachate from quartz in the El Capitan Granite and the Tonalite of the Gateway are 0.00184 and 0.00175 , respectively (Niklaus Waber, University of Bern, Switzerland, written commun., 1993). The El Capitan Granite sample is from a depth of $390 \mathrm{ft}$ below land surface in TH2, and the Tonalite of the Gateway sample is from a depth between 585 and $595 \mathrm{ft}$ below land surface in $\mathrm{TH} 1$. The $\mathrm{Br} / \mathrm{Cl} 1$ ratio in present-day ocean water is higher- 0.00347 (Morris and Riley, 1966). Because ancient sea water could have had a similar $\mathrm{Br} / \mathrm{Cl}$ ratio (Holland, 1984), these data indicate that fluid inclusions rather than ancient seawater may be the source of salinity in ground water at Wawona.

A fluid-inclusion source of chloride, however, seems inconsistent with the conclusions of Nimz and others (1993). They suggested that extremely low ratios of ${ }^{36} \mathrm{Cl}$ (36-chloride) to total $\mathrm{Cl}$ $\left({ }^{36} \mathrm{C} 1 / \mathrm{C} 1\right)$ were associated with high chloride concentrations in ground water collected from deep wells and saline springs in the foothills of the central Sierra Nevada. They suggested that the ${ }^{36} \mathrm{C} 1 / \mathrm{Cl}$ ratio should have been higher considering the availability of neutrons from radioactive decay of uranium and thorium in the granitic rocks, the chloride concentration of the ground water, and the probable residence time of the saline water. $\mathrm{Nimz}$ and others (1993) concluded that ground water 
containing high concentrations of dissolved chloride may have recently moved into granitic rocks from nongranitic rocks deeper in the crust.

\section{Tritium}

Tritium is a radioactive isotope of hydrogen. Large quantities of tritium were introduced to the atmosphere by atmospheric testing of nuclear devices between 1952 and the early 1960's (Michel, 1989). Tritium concentrations in water recharging the aquifer at Wawona varied over time in relation to tritium concentrations in precipitation. Tritium concentrations in precipitation peaked in the 1960's and since then generally have decreased in response to cessation of atmospheric nuclear testing. Because tritium has a half life of 12.4 years, tritium concentrations in ground water that originated as precipitation 12.4 years ago would be half the concentration of the original precipitation.

Tritium concentrations can be used to estimate the relative age of ground water by accounting for the radioactive decay of tritium between the time precipitation fell and the time ground water was sampled. Figure 15 shows the expected concentrations of tritium sampled in ground water at Wawona in 1991 that originated as precipitation between 1953 and 1983. The data in table 3 are ranked from lowest to highest concentrations of dissolved chloride so that differences in tritium concentrations and relative age can be related to shallow, deep, and mixed ground water. The date that the sampled ground water recharged the aquifer can be estimated by comparing the concentration of tritium in the sampled ground water (table 3) with the calculated concentration shown on figure 15 .

Ground-water samples from wells producing water from the shallow fractures contained the highest tritium concentrations (table 3 ). Because no samples contained tritium in concentrations approaching that expected in recharge from the early to mid-1960's (fig. 15), the shallow ground water probably originated as precipitation after the mid-1960's. Determining the precise age of ground water from the tritium concentrations from shallow wells is not possible because in many cases precipitation from different years has mixed in the aquifer or the well. For example, heat-pulse flowmeter measurements for well B2 (appendix A) indicate that when the well is not being pumped ground water flows down the borehole from a fracture $40 \mathrm{ft}$ below land surface and exits the well at a fracture $90 \mathrm{ft}$ below land surface. Similar mixing in the aquifer probably occurs near many other shallow wells.

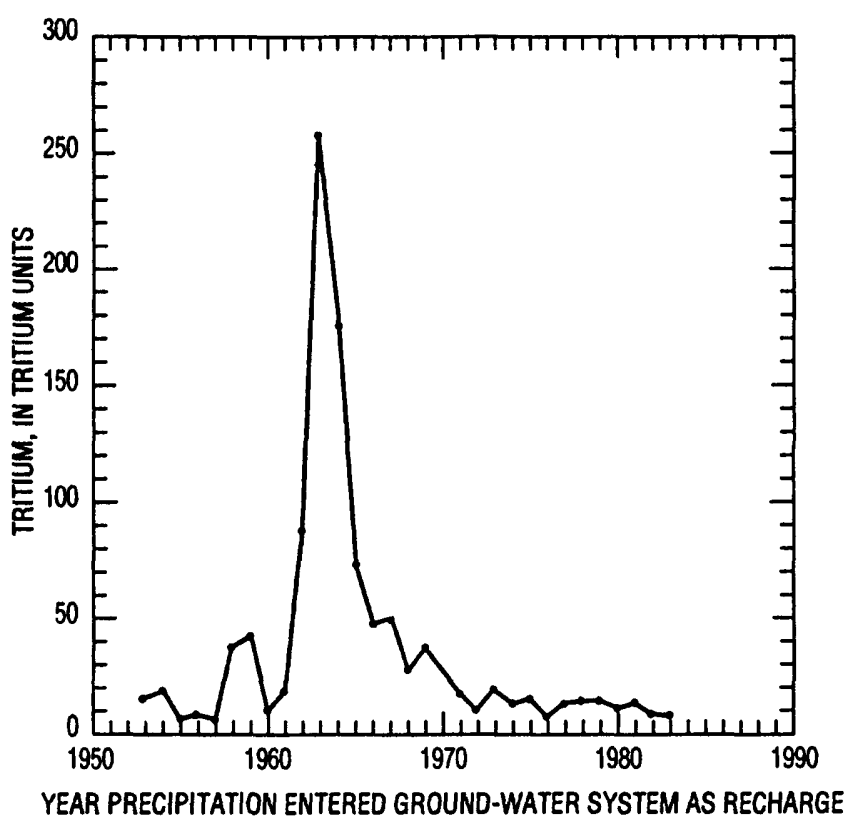

Figure 15. Tritium concentrations expected in ground water in the Wawona area that originated as precipitation between 1953 and 1983, Yosemite National Park, California. Expected concentrations were calculated by determining the radioactive decay of tritium between the time precipitation fell and the time ground water was sampled. (Modified from Michel, 1989).

Ground-water samples from the deep flowing wells contained no tritium from the period of atmospheric nuclear testing. These waters were the oldest ground waters sampled at Wawona. The meteoric component of ground water from deep flowing wells originated as precipitation prior to the early 1950's.

Ground-water samples from wells producing water from both shallow and deep fractures have intermediate tritium concentrations. The relative age of the water in these samples as interpreted from the tritium data are meaningless because the samples are a mixture of young and old water not water of intermediate age. It is likely that the proportion of shallow to deep water in a sample varies from well to well depending on the hydraulic characteristics of fractures and location of wells in the ground-water-flow field, etc.

Geophysical data collected from wells R1 and 36M1 (appendix A) indicate that, when these wells are not pumped, the boreholes allow ground water to mix in the aquifer by short circuiting flow between shallow and deep fractures. When the wells are pumped, all permeable fractures contribute to well discharge. The amount of water mixing through the boreholes depends on the transmissivity and hydraulic head of shallow and deep fractures 
Table 3. Isotopic composition of ground-water samples from wells, test holes, and springs in the Wawona area of Yosemite National Park and the Sierra National Forest, California

[Data from wells are listed in order of increasing concentrations of dissolved chloride to more readily show differences in composition among shallow, deep, and mixed ground waters. State well No.: See well- and spring-numbering system on page VII. See figure 4 for location of wells. Depth of well in feet below land surface. Producing fracture depth: D, well producing ground water only from deep fractures; S, well producing ground water only from shallow fractures; SD, well producing ground water from shallow and deep fractures. ft, foot; TU, tritium unit; TH1, test hole 1; TH2, test hole 2. do., ditto; <, actual value is less than the value shown; --, no data]

\begin{tabular}{|c|c|c|c|c|c|c|c|c|}
\hline \multirow{2}{*}{\multicolumn{2}{|c|}{$\begin{array}{c}\text { State } \\
\text { well No., } \\
\text { test hole, or } \\
\text { spring No. }\end{array}$}} & \multirow{2}{*}{$\begin{array}{c}\text { Date } \\
\text { sampled }\end{array}$} & \multirow{2}{*}{$\begin{array}{l}\text { Sampling } \\
\text { condition }\end{array}$} & \multirow{2}{*}{$\begin{array}{l}\text { Producing } \\
\text { fracture } \\
\text { depth }\end{array}$} & \multirow{2}{*}{$\begin{array}{l}\text { Depth } \\
\text { of } \\
\text { well } \\
\text { (ft) }\end{array}$} & \multicolumn{2}{|c|}{ Stable isotope ratio, permil } & \multirow{2}{*}{$\begin{array}{c}\text { Tritium, } \\
\text { total } \\
\text { (TU) }\end{array}$} \\
\hline & & & & & & $\begin{array}{c}\text { Delta } \\
\text { oxygen-18 }\end{array}$ & $\begin{array}{c}\text { Delta } \\
\text { deuterium }\end{array}$ & \\
\hline \multirow{33}{*}{ 4S/21E- } & $35 \mathrm{P} 1$ & $9-17-91$ & Pumped & $S$ & 68 & -11.65 & -81.5 & 9.1 \\
\hline & $35 \mathrm{D} 6$ & $9-10-91$ & do. & $S$ & 400 & -12.10 & -85.5 & 9.0 \\
\hline & 35E1 & $9-09-91$ & do. & $S$ & 250 & -11.90 & -84.0 & 7.4 \\
\hline & $35 \mathrm{C} 8$ & $9-12-91$ & do. & $S$ & 87 & -11.75 & -82.5 & 14.7 \\
\hline & 35D9 & $9-09-91$ & do. & $S$ & 200 & -11.95 & -83.0 & 9.7 \\
\hline & $35 \mathrm{C} 4$ & $9-12-91$ & do. & $S$ & 60 & -11.90 & -85.0 & 13.5 \\
\hline & $35 \mathrm{C} 2$ & $9-13-91$ & do. & $S$ & -- & -12.15 & -86.5 & 12.5 \\
\hline & $35 \mathrm{~B} 1$ & $9-15-91$ & do. & $S$ & 90 & -11.75 & -83.5 & 13.6 \\
\hline & $35 \mathrm{H} 1$ & $9-15-91$ & do. & $S$ & 114 & -11.80 & -84.5 & 15.3 \\
\hline & $35 \mathrm{C} 5$ & $9-13-91$ & do. & $S$ & 107 & -11.85 & -83.5 & 16.2 \\
\hline & $35 \mathrm{Cl}$ & $9-14-91$ & do. & $S$ & 95 & -12.00 & -86.0 & 13.2 \\
\hline & $35 \mathrm{E} 12$ & $9-10-91$ & do. & $S$ & 200 & -11.85 & -84.0 & 10.7 \\
\hline & 35D5 & $9-10-91$ & do. & $S$ & 34 & -11.85 & -83.0 & 8.4 \\
\hline & $35 \mathrm{H} 9$ & $9-12-91$ & do. & $S$ & 62 & -11.90 & -85.0 & 14.8 \\
\hline & $35 \mathrm{E} 3$ & $9-11-91$ & do. & $S$ & 300 & -11.75 & -83.0 & 11.3 \\
\hline & 35D1 & $9-10-91$ & do. & $S$ & 54 & -11.65 & -85.0 & 12.1 \\
\hline & $35 \mathrm{C} 13$ & $9-14-91$ & do. & $S$ & 85 & -11.80 & -84.0 & 13.1 \\
\hline & $35 \mathrm{C} 3$ & $9-19-91$ & do. & $S$ & 143 & -12.00 & -86.0 & 9.7 \\
\hline & $35 \mathrm{~F} 7$ & $9-11-91$ & do. & $S$ & 94 & -11.95 & -86.5 & 14.8 \\
\hline & $35 \mathrm{~B} 2$ & $9-15-91$ & do. & $S^{1}$ & 138 & -11.90 & -83.5 & -- \\
\hline & $35 \mathrm{M} 2$ & 9-19-91 & do. & $S$ & 49 & -11.70 & -82.5 & 11.6 \\
\hline & $35 R 2$ & $9-18-91$ & do. & $S$ & 96 & -12.05 & -85.5 & -- \\
\hline & $35 \mathrm{E} 2$ & $9-11-91$ & do. & S & 90 & -11.70 & -83.0 & 12.2 \\
\hline & $35 \mathrm{M} 7$ & $9-16-91$ & do. & $S$ & 190 & --11.50 & -80.5 & -- \\
\hline & $35 \mathrm{E} 16$ & $9-16-91$ & do. & $S$ & 133 & -11.70 & -82.5 & 7.5 \\
\hline & $35 \mathrm{~F} 1$ & $9-15-91$ & do. & $S$ & 71 & -12.15 & -86.0 & 11.9 \\
\hline & $35 \mathrm{P} 4$ & $29-19-91$ & do. & SD & 300 & -12.50 & -88.0 & - \\
\hline & $35 \mathrm{P} 4$ & ${ }^{3} 9-19-91$ & do. & SD & 300 & -12.15 & -85.5 & 4.7 \\
\hline & $35 \mathrm{E} 17$ & $9-14-91$ & do. & SD & 300 & -12.45 & -88.0 & 3.1 \\
\hline & 35R1 & $9-17-91$ & do. & $\mathrm{SD}^{1}$ & 1,235 & -12.60 & -88.0 & 2.2 \\
\hline & $35 \mathrm{E} 9$ & $9-25-91$ & do. & SD & 740 & -11.80 & -83.0 & 11.9 \\
\hline & $36 \mathrm{M} 1$ & $9-17-91$ & $\begin{array}{l}\text { do.; flowing } \\
\text { when unpumped }\end{array}$ & $\mathrm{SD}^{1}$ & 900 & -13.65 & -98.0 & .6 \\
\hline & $\mathrm{TH} 2^{4}$ & $8-23-92$ & Flowing & $\mathrm{D}^{1}$ & 425 & -13.40 & -95.0 & $<.3$ \\
\hline \multirow[t]{6}{*}{$4 \mathrm{~S} / 21 \mathrm{E}-$} & $35 \mathrm{G} 2$ & $9-27-91$ & do. & D & 400 & -13.35 & -94.5 & $<.3$ \\
\hline & $35 \mathrm{Gl}$ & $9-16-91$ & do. & D & 480 & -13.30 & -95.0 & $<.3$ \\
\hline & $35 \mathrm{G} 3$ & $10-29-91$ & do. & D & 600 & -13.25 & -94.5 & .3 \\
\hline & $\mathrm{TH}^{4}$ & $10-26-93$ & do. & $\mathrm{D}^{1}$ & 425 & -13.44 & -96.3 & $<.3$ \\
\hline & TH1 $1^{5}$ & $8-24-92$ & do. & $\mathrm{D}^{1}$ & 1,027 & -13.55 & -96.0 & $<.3$ \\
\hline & $\mathrm{TH}^{5}$ & $10-26-93$ & do. & $D^{1}$ & 1,027 & -13.83 & -99.4 & $<.3$ \\
\hline \multirow[t]{2}{*}{$5 \mathrm{~N} / 22 \mathrm{E}-$} & $-16 \mathrm{AS} 1^{4}$ & $9-18-91$ & Flowing & -- & - & -13.15 & -90.5 & 12.4 \\
\hline & $16 \mathrm{BS} 1^{5}$ & $9-18-91$ & do. & -- & -- & -13.25 & -91.5 & 9.1 \\
\hline
\end{tabular}

${ }^{1}$ Borehole geophysical data confirm producing fracture depth.

${ }^{2}$ Sample taken at 11:18.

${ }^{3}$ Sample taken at 13:15.

${ }^{4}$ Biledo Spring.

${ }^{5}$ Biledo Meadow spring 1. 
and on the length of time that the wells are not pumped. Changes in temperature, specific conductance, and $\mathrm{pH}$ indicate that the proportion of shallow to deep ground water in well discharge varies with time as the wells are pumped. Most samples collected for tritium concentrations were collected 2 to 4 weeks later than the samples collected for inorganic chemical analysis. It is likely that the tritium and other isotope samples might represent different proportions of shallow and deep water than the inorganic samples because hydraulic-head condi-tions, presampling pumping history, and sample pumping times were different.

\section{Stable Isotopes}

The proportion of the heavy stable isotopes of oxygen $\left({ }^{18} \mathrm{O}\right)$ and hydrogen $\left[{ }^{2} \mathrm{H}\right.$, (deuterium)] in water molecules can be used to infer the source and evaporative history of water. Both isotopes are reported as ratios relative to Vienna Standard Mean Ocean Water (V-SMOW) in the permil notation (Gat and Gonfiantini, 1981). The ratios of both isotopes are relatively constant at a given latitude in atmospheric moisture over the oceans. Water molecules composed of oxygen-18 and deuterium atoms need slightly more energy to evaporate than water molecules composed of lighter oxygen $\left({ }^{16} \mathrm{O}\right)$ and hydrogen $\left({ }^{1} \mathrm{H}\right)$ atoms. Thermodynamic processes slightly favor the condensation of water vapor containing oxygen-18 and deuterium. Condensation of water vapor containing oxygen- 18 and deuterium occurs at higher temperatures than condensation of water vapor containing ${ }^{16} \mathrm{O}$ and ${ }^{1} \mathrm{H}$. As water droplets repeatedly undergo evaporation and condensation, the aqueous phase becomes isotopically heavier and the vapor phase becomes isotopically lighter. Generally, as atmospheric moisture moves inland from coastal areas, the concentration of the heavy isotopes decreases relative to the concentrations of lighter isotopes. Heavy isotopes are more concentrated during initial precipitation, which occurs at lower altitudes in coastal areas, and most depleted during later precipitation, which occurs inland at higher altitudes. Oxygen-18 and deuterium are affected similarly by this isotopic fractionation process; a plot of the isotopic ratios of oxygen-18 to deuterium in precipitation is a straight line with a slope similar to the global meteoric water line (Gat and Gonfiantini, 1981). The position of a stable-isotopic analysis relative to the line of isotopic fractionation is controlled by temperature and storm duration.

Figure 16 shows the relation between oxygen18 and deuterium for all ground-water samples collected in the Wawona area. A local meteoric water line has not been developed for the Wawona

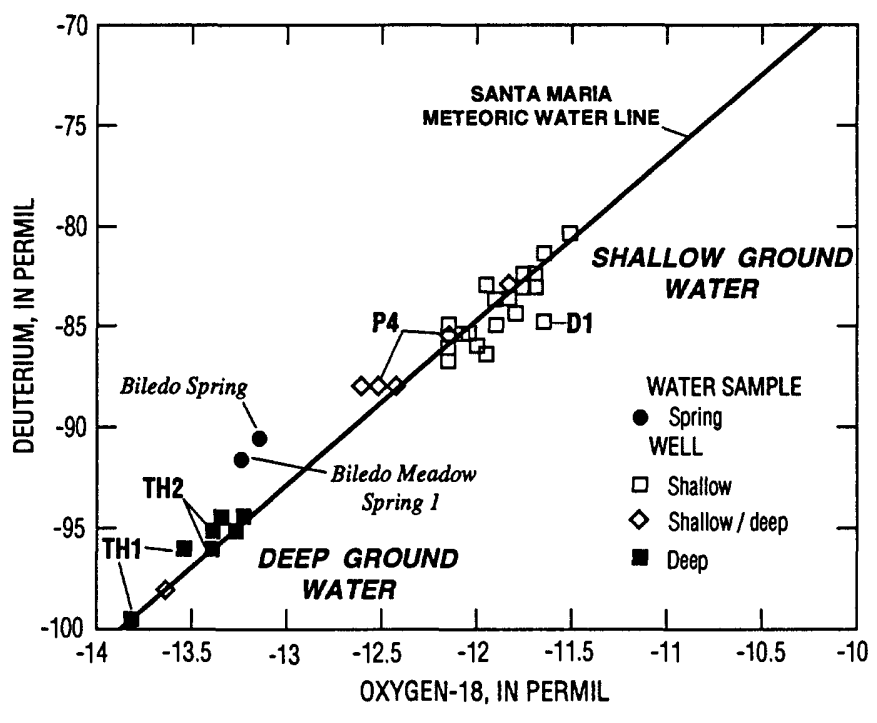

Figure 16. Relation between deuterium and oxygen18 for all ground-water samples from the Wawona area, Yosemite National Park, California. The Santa Maria meteoric water line is defined by precipitation collected at Santa Maria, California (International Atomic Energy Agency, 1981).

area, but the stable-isotopic composition of groundwater samples collected in this area plots generally on the meteoric water line defined by precipitation collected at Santa Maria, Calif. (International Atomic Energy Agency, 1981). Samples having stable-isotopic compositions that do not plot on the meteoric water line could indicate that the ground water is from a different source or that the ground water has a different fractionation history. For example, ground water from the high-altitude springs near Biledo Meadow (fig. 1) may be recharged by snowmelt that has been depleted in heavy isotopes by atmospheric processes within the snow pack. Evaporation of shallow ground water may have caused water from well D1, which is very shallow (54 ft deep), to be isotopically heavy.

Because the isotopic composition of ground water usually is similar to the mean isotopic composition of precipitation in the recharge area of an aquifer (Gat and Gonfiantini, 1981), differences in the isotopic composition of ground-water samples from different wells could help identify the recharge areas for parts of the aquifer at Wawona that are tapped by wells. Ground water from the shallow wells at Wawona is isotopically heavier (contains more oxygen-18 and deuterium) than ground water from deeper wells (fig. 16). This suggests that the meteoric component of ground water in the shallow wells condensed at warmer temperatures, that is, fell 
as precipitation at a lower altitude or in a climatically warmer period than the ground water in the deep wells. The shallow wells tap a local groundwater-flow system that has been recharged by precipitation that fell on the hillsides near or upslope of the wells probably less than 20 years ago (see "Tritium" section).

The deep flowing wells at Wawona produce ground water with an isotopic composition that falls on the same meteoric water line as the ground water produced by the shallow wells. This indicates that ground water in deep fractures is derived primarily from precipitation falling at the same latitude as precipitation recharging shallow fractures. Because ground water in the deep wells is isotopically lighter than ground water in the shallow wells (fig. 16 ), it probably condensed as precipitation at colder temperatures either during a cooler climate or at higher altitudes or both.

Recharge temperatures for ground water sampled from wells and springs in the foothills of the central Sierra Nevada were calculated by Hudson and others (1993) using concentrations of dissolved noble gases. They concluded that the meteoric component of deep, saline ground water in this area recharged aquifers during a cooler climate, perhaps thousands of years ago.

If fractionation between shallow and deep ground water at Wawona (fig. 16) was entirely due to differences in the altitude of precipitation recharging these waters, then the difference in altitudes of the recharge areas could be estimated using relations between altitude of precipitation and deuterium content of storms moving eastward over the Sierra Nevada (Smith and others, 1979; Davis and Coplen, 1989). The change with altitude in the deuterium content of rain and snow falling in Wawona probably is about 15 permil per $3,000 \mathrm{ft}$ of altitude change. The change is much higher for snow falling at higher altitudes-about 40 to 50 permil per 3,000 ft of altitude change. These two values were used to calculate the change in deuterium content of precipitation with altitude. The results indicate that ground water from the TH1 sample, which was isotopically lighter (sampled October 26, 1993, table 3), originated as precipitation from clouds that were between 1,400 and $3,700 \mathrm{ft}$ higher than the clouds providing precipitation that recharged the isotopically heaviest ground water in Wawona. If the base of storm clouds can be assumed equidistant from land surface in both recharge areas, the altitude of the recharge areas should differ similarly. The estimated altitude of the recharge areas contain additional uncertainty because of the possible effect of the isotopic composition of the saline source water (fluid inclusions or connate water).
Two stable isotope samples were collected from TH1, TH2, and well P4 (table 3). The duplicate samples had different stable isotopic compositions (fig. 16, table 3). These differences generally are greater than the precision of the analytical technique (0.1 permil for oxygen-18 and 1 permil for deuterium) and probably are caused by differences in the proportion of old, deep ground water in the samples. The isotopically lighter samples from TH1 and TH2 were collected near the end of long-term flow tests when specific conductance in water flowing from the test holes had increased by more than 50 percent (table 2) (see "Water-Supply Alternatives for Wawona" section).

Changes in isotopic content, $\mathrm{pH}$, specific conductance, temperature, and dissolved-oxygen concentrations in well $\mathrm{P} 4$ during pumping indicate that the well produces dilute ground water from shallow fractures and more mineralized ground water from deep fractures. The isotopically lighter sample is more mineralized than the isotopically heavier sample (specific conductance, 270 and 212 $\mu \mathrm{S} / \mathrm{cm}$, respectively). The isotopically lighter sample is anoxic, has a higher $\mathrm{pH}$ (7.9), and is warmer $\left(11.0^{\circ} \mathrm{C}\right)$ than the oxygenated, isotopically heavier sample ( $\mathrm{pH} \mathrm{7.2,} \mathrm{temperature} 10.5^{\circ} \mathrm{C}$ ). Bore-hole geophysical logging confirmed that similar changes in water-quality characteristics during pumping of wells 35R1 and 36M1 were the result of differences in the chemical content of ground water in shallow and deep fractures.

Well P4 had not been pumped several days prior to sampling. The first sample was collected 2 hours before the second sample. The water from the first sample was isotopically lighter (table 3). Considering the vertical segregation of the natural ground-water-flow system in the South Fork Merced River valley, it is likely that prior to pumping well P4, mineralized ground water in deep fractures flowed up the well bore and exited at shallower fractures. When pumping began, most of the water in the well and in the fractures near the well originated from the deeper fractures. The first sample contained a large proportion of the isotopically light, deep ground water. Two hours later, after pumping had removed the water from shallow fractures that had originated in the deep fractures, the sample contained a larger proportion of isotopically heavier water from the shallow flow system. This interpretation is consistent with the inorganic chemical composition of water from well P4, sampled 2 weeks earlier. The water is intermediate in composition and probably a mix of dilute calcium sodium bicarbonate water typical of shallow fractures and a more mineralized sodium calcium chloride water typical of deeper fractures (fig. 13). 


\section{Ground-Water-Quality Conditions}

Ground water from all wells sampled in Wawona meets the primary drinking-water standards of the State of California and the U.S. Environmental Protection Agency for inorganic constituents (State of California, 1993). The primary drinking-water standards are the maximum contaminant levels permitted in water entering a public water-distribution system. These standards are designed to protect public health. Data for inorganic constituents in well, spring, and stream water in the Wawona area are published in "U.S. Geological Survey Water-Resources Data--Ground Water, California, 1991," by Johnson and others (1991).

Several ground-water samples exceeded the U.S. Environmental Protection Agency's and the State of California's secondary maximum contaminant-level standards. Secondary maximum contaminant levels control the taste, odor, or appearance of drinking water. For example, iron and manganese are generally considered only aesthetic problems, staining bathroom and kitchen fixtures but causing no health risk. Four of 43 wells sampled exceeded the secondary maximum contaminant level for dissolved iron, with an obvious buildup of iron bacterial slime in 1 well; 3 of 43 wells exceeded the secondary maximum contaminant level for manganese (Johnson and others, 1991). Dissolved iron causes aesthetic problems when the ground water is anoxic-contains little oxygen. When such ground water is exposed to the atmosphere, usually at faucets and other plumbing fixtures, dissolved iron oxidizes and precipitates out of solution as ferric oxyhydroxides. The granitic rocks at Wawona contain iron-bearing minerals, such as biotite and amphibole, which are a source of iron to ground water.

One well exceeded the U.S. Environmental Protection Agency's secondary maximum contaminant level of $5 \mathrm{mg} / \mathrm{L}$ for dissolved zinc (State of California, 1993). Because zinc-bearing minerals are not common in granitic rocks, the zinc is believed to come from a galvanized pressure tank and discharge piping.

Samples from TH1 (table 2) exceeded the secondary maximum contaminant level for total dissolved solids.

All well water sampled at Wawona exceeded the proposed Federal primary drinking-water standard for dissolved ${ }^{222}$ radon of $300 \mathrm{pC} / \mathrm{L}$ (State of California, 1993) (fig. 17). Dissolved ${ }^{222}$ radon, a radioactive gas, is one of a series of elements in the decay chain of uranium and thorium, which naturally occur in granitic rocks. Particles emitted during the decay of dissolved ${ }^{222}$ radon and its daughter products are carcinogenic, causing damage to lung

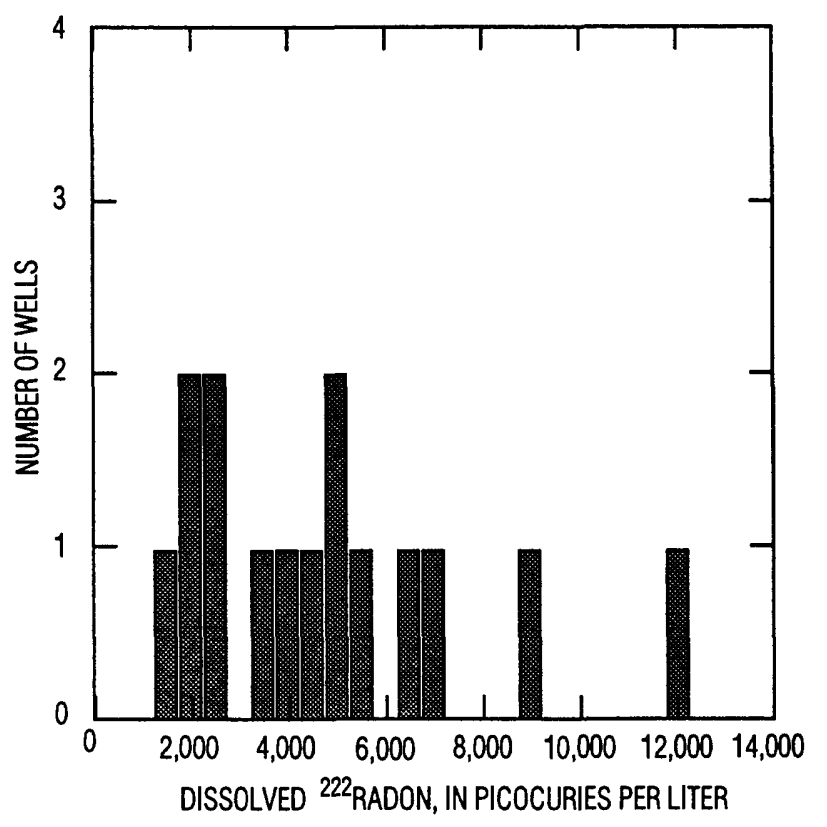

Figure 17. Distribution of dissolved ${ }^{222}$ radon in groundwater samples from wells in the Wawona area, Yosemite National Park, California.

tissue (U.S. Environmental Protection Agency, 1991). Damage to tissue in the digestive track by water containing dissolved ${ }^{222}$ radon has not been quantified. Because most domestic water systems at Wawona are pressurized from the well to the faucet, water does not degas and vent the dissolved ${ }^{222}$ radon until it is inside the home. The proposed maximum contaminant level for dissolved ${ }^{222}$ radon in drinking water was established to minimize the concentration of radon in indoor air. Dissolved ${ }^{222}$ radon can be removed from ground water by air sparging and by venting storage tanks.

\section{Well Yield}

Generally, yields from wells drilled in the fractured granitic rocks at Wawona are low. Short (5- to 60-minute) pumping tests were run on 40 nonflowing (pumped) wells prior to sampling water for chemical analysis and on 2 other nonflowing wells. Water-level drawdown during pumping indicated that most wells are pumped at rates that cannot be sustained by the fractures intersecting the well and that much of the pump discharge is supplied by water stored in the 6- or 8-in. diameter wellbores. Because much of the discharge during these short tests was from wellbore storage, quantitative analysis of the relation between water-level drawdown and time of pumping was not possible. During most of the pumping tests, the rate of drawdown slowed, the amount of water produced from 
wellbore storage decreased, and the percentage of the pumped discharge from the aquifer increased with time. The production rate of water from the aquifer at the end of 30 minutes was used as an estimate of short-term yield of 38 tested wells and ranged from 0.1 to $19 \mathrm{gal} / \mathrm{min}$ (fig. 18). Short-term yields were not determined for deep flowing wells in the valley floor.

Drillers' estimates of well yield, which generally are based on the volume rate of water brought to the surface by an air-rotary drilling rig at the end of a test period, were available for 14 of the 38 wells tested. The length of a driller's test can vary from minutes to hours. Drillers' estimates also should be considered short-term yields. A comparison of drillers' estimated yields with yields from the pumping tests is shown in figure 18. A point on either curve represents the cumulative percentage of wells with a yield less than that represented by the point. The curves are very similar. About 57 percent of the wells in each distribution have yields less than or equal to $5 \mathrm{gal} / \mathrm{min}$. The median yield for both estimates is between 4 and $5 \mathrm{gal} / \mathrm{min}$.

Quantifying well yield is a subjective task and is particularly difficult in fractured-rock aquifers. Wells initially having a high yield commonly experience a drastic drop in yield or go dry once the fractured area is drained. Swanson (1979) determined that well yields decreased between 50 and 90 percent of their initial pumping rate during longterm constant-head pumping tests in fractured granitic and metamorphic rocks of the central Sierra Nevada foothills. Most of the tests by Swanson were done during the dry season for a duration of 50 to 100 days. In the winter following the tests, most well yields recovered to their initial rate. Similar decreases in well yield were observed by Schmidt (1977; consultant, written commun., 1994) during long-term pumping tests of wells drilled in fractured granitic rocks in the foothills of the southern Sierra Nevada. The results of the tests by Swanson and Schmidt indicate that short-term yields are not reliable for determining long-term production estimates. The median yield (4 to 5 $\mathrm{gal} / \mathrm{min}$ ) of wells at Wawona probably could not be sustained during long-term pumping.

The relation between well yield and well depth at Wawona generally is poor (fig. 19). The greatest probability of high yields (more than $10 \mathrm{gal} / \mathrm{min}$ ) is from wells that are less than $100 \mathrm{ft}$ in depth. Six of 20 wells with depths of less than $100 \mathrm{ft}$ yield 10 $\mathrm{gal} / \mathrm{min}$ or more, but only 1 of 9 wells with depths between 100 and $200 \mathrm{ft}$ deep and 1 of 9 wells with depth greater than $200 \mathrm{ft}$ yield more than $10 \mathrm{gal} /$ min (fig. 19). High-yielding shallow wells may intersect shallow, open, sheeting fractures that occur near land surface. If a well does not intersect permeable fractures at a shallow depth, a driller proba-

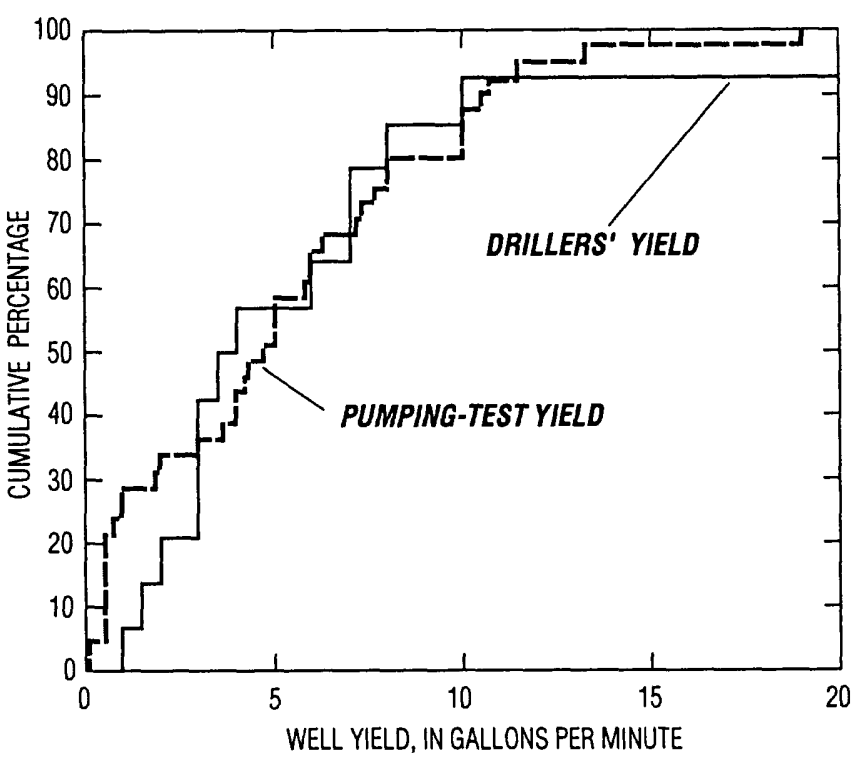

Figure 18. Comparison of driller's estimated yield with short-term pumping-test yields for wells in the Wawona area, Yosemite National Park, California. A point on either curve represents the cumulative percentage of wells with a yield less than that represented by the point.

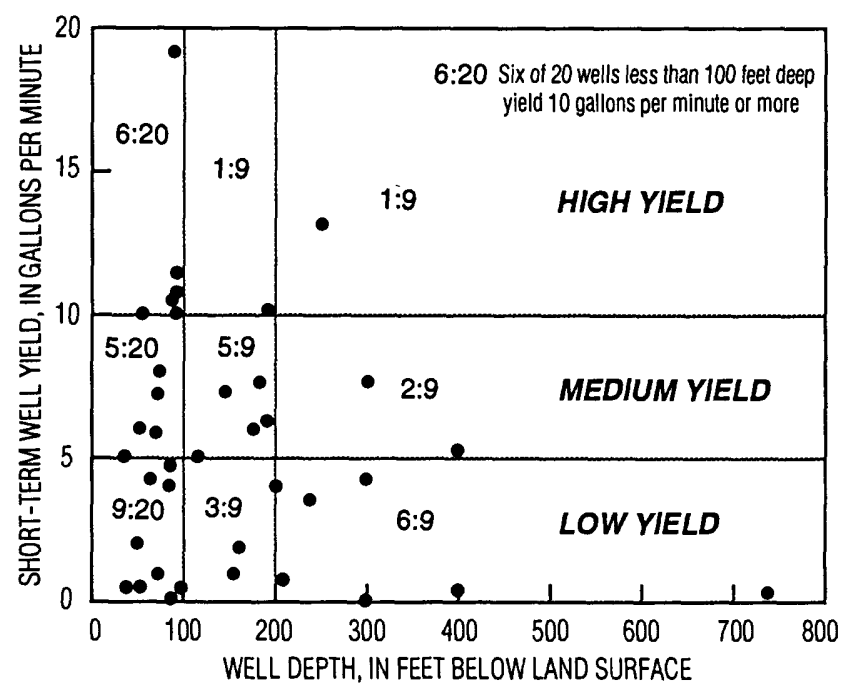

Figure 19. Relation between short-term well yield and well depth for wells in the Wawona area, Yosemite National Park, California. The terms low, medium, and high describe relative yield of wells at Wawona.

bly would continue to drill until obtaining an adequate yield from a deep water-bearing fracture. If no highly productive fractures are encountered, a deep well could provide adequate water for a single-family residence because the well could act as a cistern for ground water that seeps slowly from less productive fractures into the wellbore. A rela- 


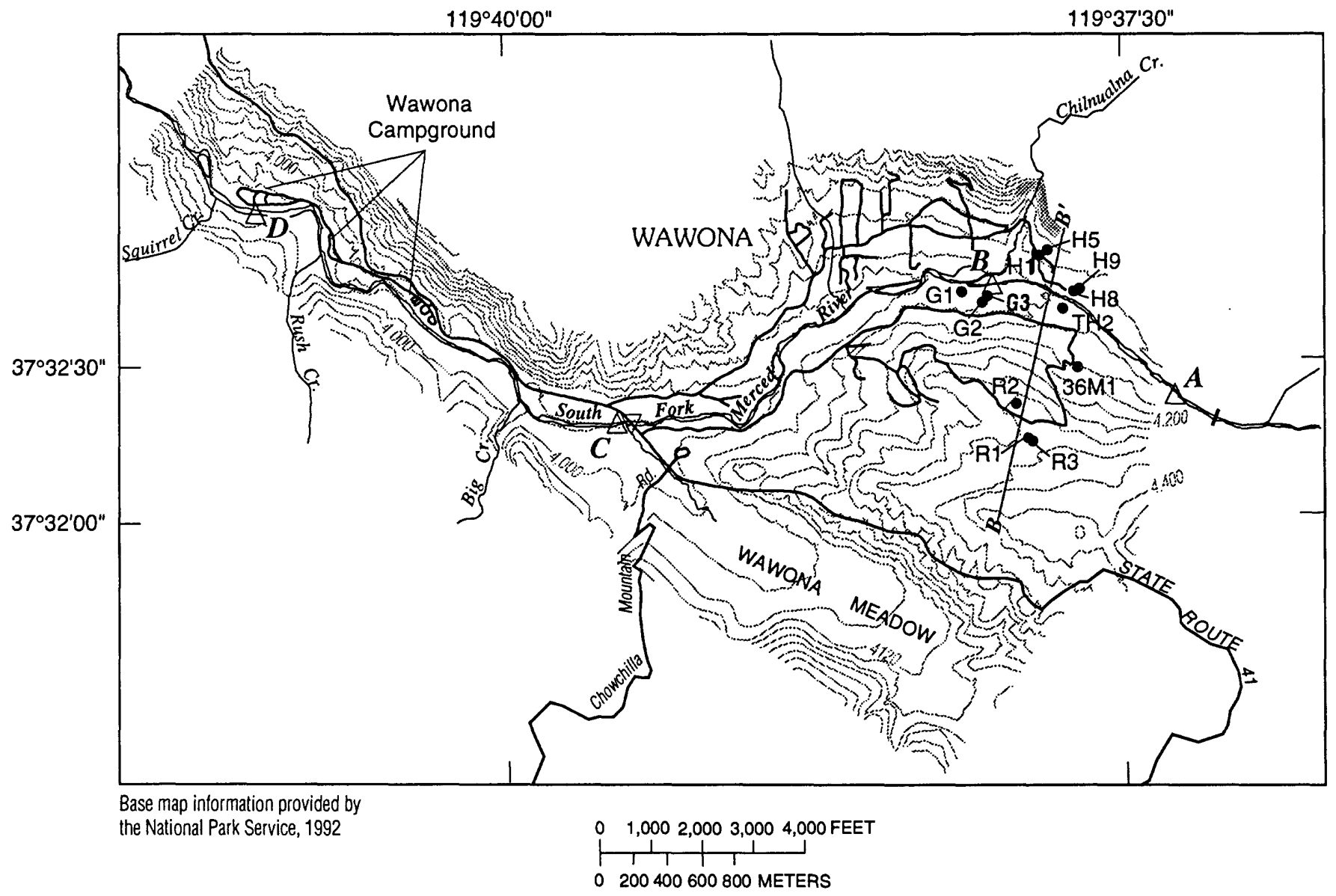

EXPLANATION
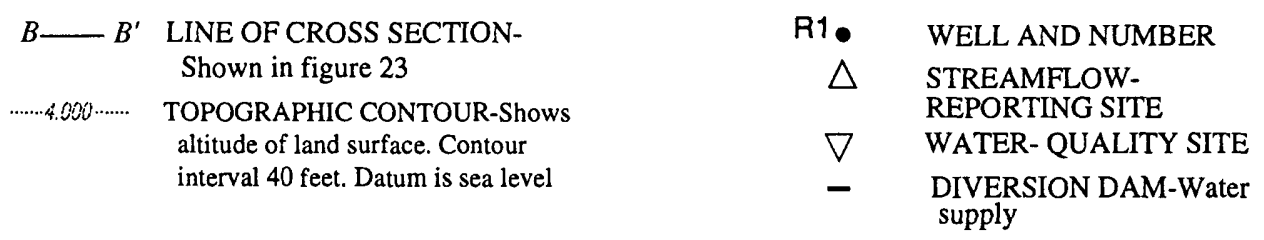

Figure 20. Location of streamflow reporting sites on the South Fork Merced River, wells in the losing reach of the river, and section B-B', Yosemite National Park, California. (Section shown in figure 24).

tion between well yield and well diameter, saturated thickness of the fractured rocks penetrated by the well, topographic location, or rock type is not apparent nor is there an apparent relation between the location of high yield wells and fracture traces.

Because fracture traces are obscured by vegetation, soil, till, or alluvium covering the bedrock in the South Fork Merced River valley near the wells, no definitive conclusions regarding the lack of a relation between yield and fracture traces can be made.

Well yield can often be increased by hydraulically pressurizing isolated intervals of the wellbore causing fractures to open, thereby improving permeability and interconnection with other fractures. Paillet and Rule (1994) determined that hydraulic stimulation is most successful in increasing production from low-yielding wells. Occasionally, yields were increased by as much as 100 percent, but because initial yields were low, the wells remained poor producers. Use of hydraulic stimulation techniques probably would not create high-yielding wells for ground-water production in Wawona.

\section{Relation to Flow in the South Fork Merced River}

Four stream gain-and-loss studies were done on three reaches of the South Fork Merced River between streamflow reporting sites A and D (fig. 20) 


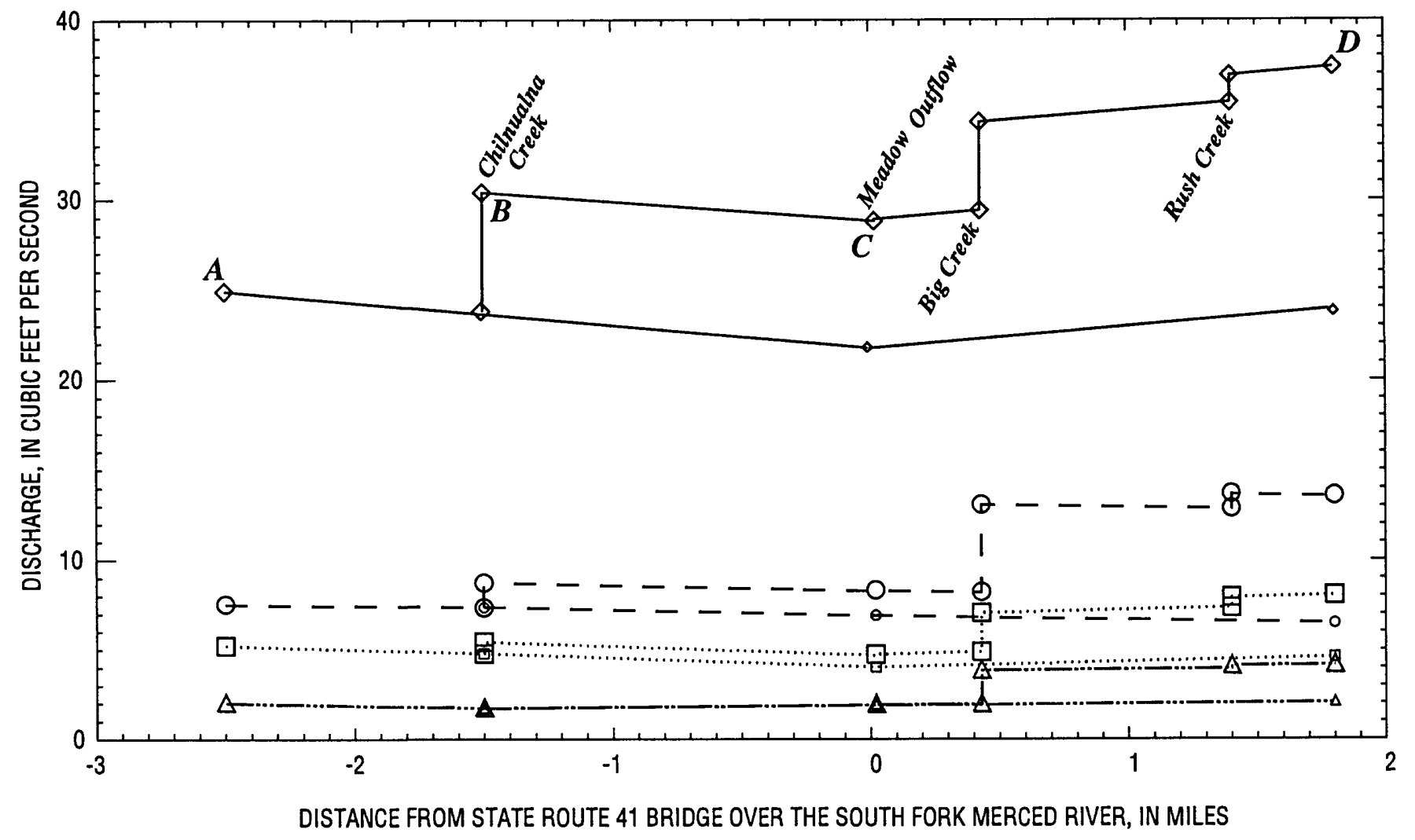

EXPLANATION
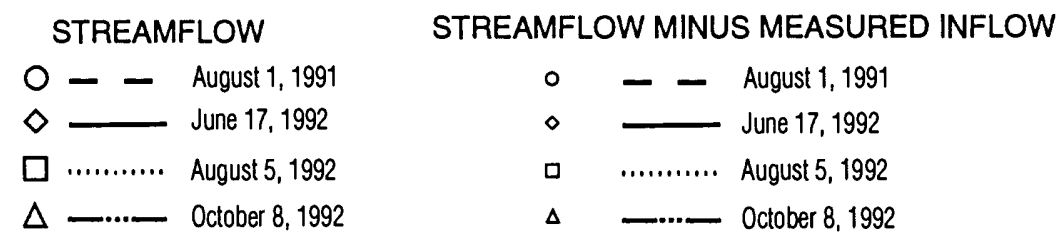

Figure 21. Discharge of the South Fork Merced River at streamflow reporting sites during gain-and-loss studies between August 1, 1991, and October 8, 1992, Yosemite National Park, California.

during the dry seasons between August 1,1991 , and October 8, 1992. Discharge at the streamflow reporting sites for each of the four studies is shown on figure 21. Gain or loss was computed for each reach by subtracting tributary inflow and flow at an upstream site from flow measured at a downstream site. Streamflow measurements made during gainand-loss studies on the South Fork Merced River are published in a report by Mullen and others (1993).

Cumulative gains and losses in flow for each study are shown in figure 22 , with the positive slope indicating flow gains and the negative slope indicating flow losses. The magnitudes of gain and loss were within the expected measurement error for all stream-discharge measurements. However, because the gains and losses occurred in the same reaches and were about the same percentage of streamflow regardless of the magnitude of the flow, the South Fork Merced River probably loses flow between sites $A$ and $C$, (fig. 20) and then regains flow in the most downstream reach (between sites $C$ and D, fig. 20). The data indicate that between sites A and D the South Fork Merced River does not gain appreciable flow from the ground-waterflow system during the dry season.

Hydraulic head in deep wells near the South Fork Merced River (between sites A and B, fig. 23) is more than $150 \mathrm{ft}$ above the river. The water table, defined by hydraulic head in the shallow wells near the center of the valley, is about at river level. The hydraulic gradient between shallow and deep wells in the fractured rocks beneath the river is strongly upward, indicating that a potential exists 


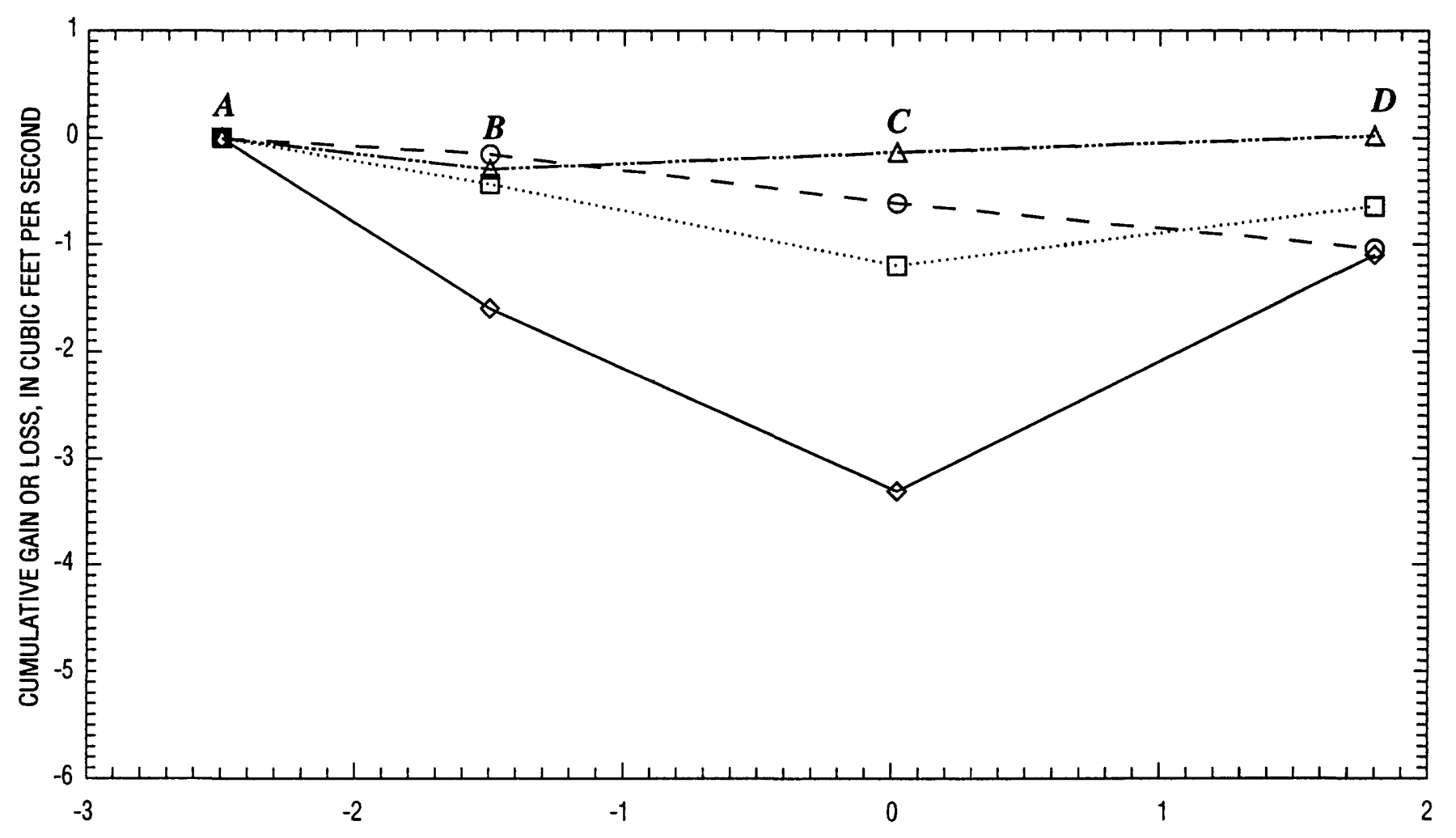

DISTANCE FROM STATE ROUTE 41 BRIDGE OVER THE SOUTH FORK MERCED RIVER, IN MILES

\section{EXPLANATION}

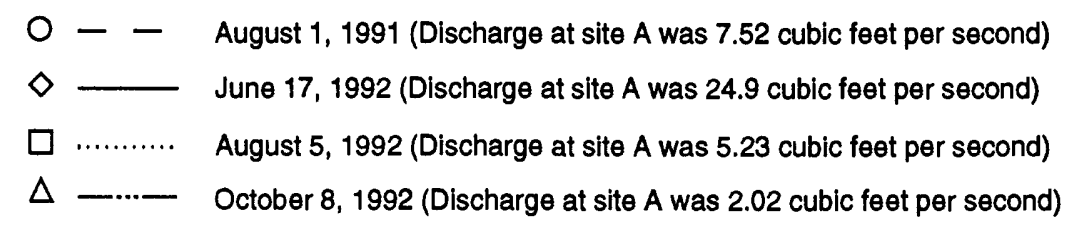

Figure 22. Cumulative gains or losses in flow of the South Fork Merced River at streamflow reporting sites between August 1, 1991, and October 8, 1992, Yosemite National Park, California.

for ground water to flow toward the river from the deep fractures. However, the river is losing water to the ground water system in this reach (figs. 21 and 22).

Hydraulic-head and water-chemistry data collected from shallow and deep wells in the South Fork Merced River valley indicate that upward vertical flow from deep fractures is impeded. This restriction to upward vertical flow may prevent the deep, pressurized ground-water-flow system from discharging to the South Fork Merced River in the Wawona area. Using discharge and specific conductance data collected during a gain-and-loss study on June 17, 1992, at sites C and D and at all tributaries to the intervening reach, mass balance indicates that water discharging to the South Fork
Merced River in the area between sites C and D on figure 20 has a specific conductance of about $18 \mu \mathrm{S} / \mathrm{cm}$ (table 4). This value is similar to the values measured at sites $A, B$, and $C$, which had a specific conductance of 18,18 , and $22 \mu \mathrm{S} / \mathrm{cm}$, respectively (table 4 ), but is not representative of ground water in the shallow or deep wells, which had values for specific conductance ranging from 64 to 207 and 369 to $2,350 \mu \mathrm{S} / \mathrm{cm}$, respectively (table 2). Gains in flow between sites C and D downstream of the State Route 41 bridge probably resulted because of reemerging streamflow that infiltrated the alluvium in the riverbeds of losing reaches (between sites A and C, fig. 20) and probably was not ground water that discharged from fractured rocks beneath the valley floor. 


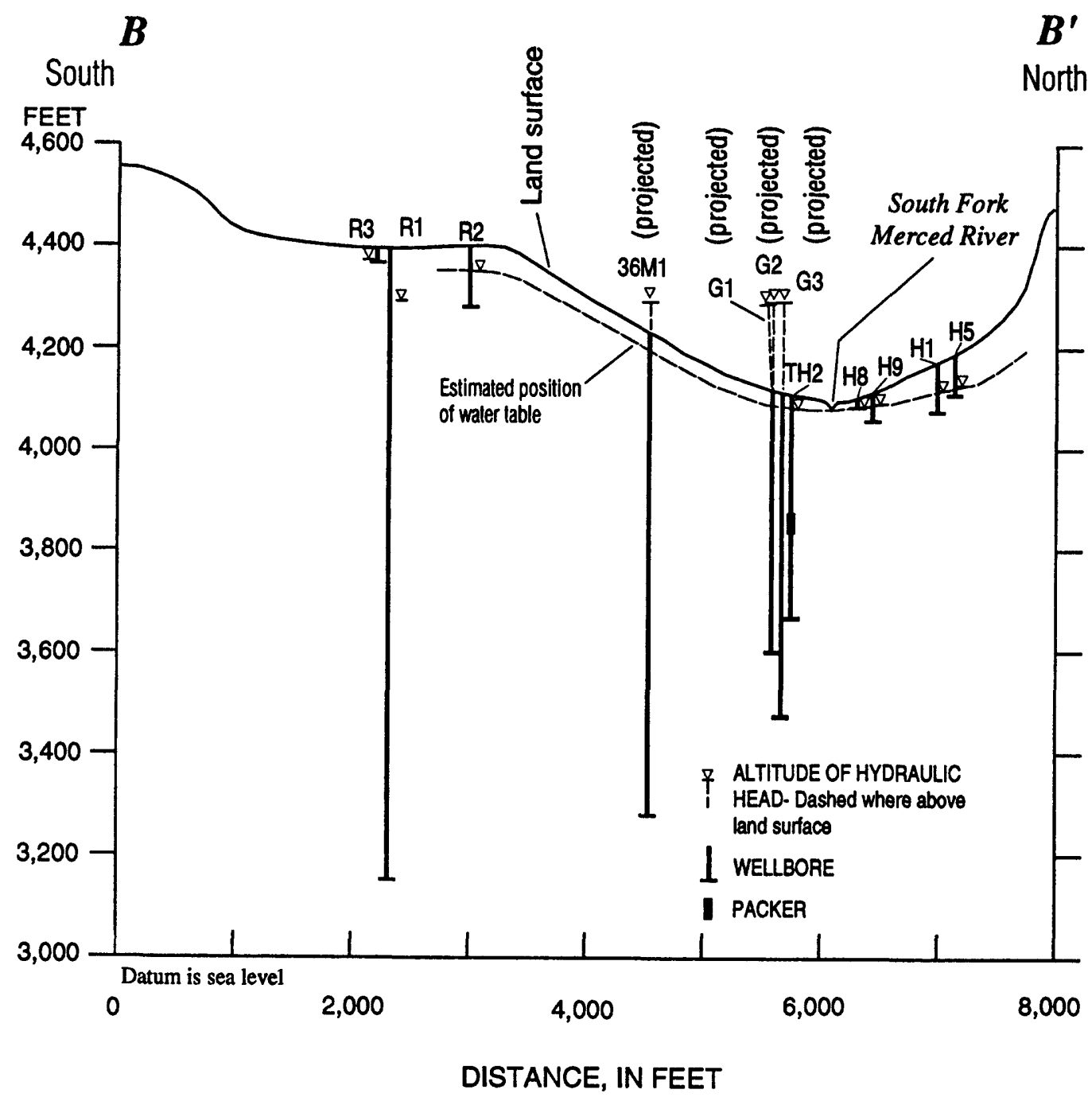

Figure 23. Relation between hydraulic head in shallow and deep wells in the losing reach of the South Fork Merced River (between sites A and B, figure 20) during the gain-and-loss study on August 5, 1992, Yosemite National Park, California. (Note: The hydraulic head for all wells is the composite head for fractures between land surface and the bottom of the wells. Hydraulic head in test hole 2 represents the shallow ground-water-flow system. It was measured by installing a hydraulic packer in the borehole 230 feet below land surface so that high hydraulic head (about 140 feet above land surface) in the deeper fractures would not influence the measurement.) 
Table 4. Streamflow and specific conductance data used to calculate discharge and specific conductance of unmeasured inflow to the South Fork Merced River between streamflow reporting sites $C$ and $D$ near Wawona, Yosemite National Park, California

[ $\mathrm{ft}^{3} / \mathrm{s}$, cubic foot per second; $\mu \mathrm{S} / \mathrm{cm}$, microsiemen per centimeter at 25 degrees Celsius]

\begin{tabular}{cccc}
\hline $\begin{array}{c}\text { Streamflow } \\
\text { reporting } \\
\text { site }\end{array}$ & $\begin{array}{c}\text { Inflow to South Fork } \\
\text { Merced River between } \\
\text { sites C and D }\end{array}$ & $\begin{array}{c}\text { Discharge } \\
(\mathrm{Q}) \\
\left(\mathrm{ft}^{3} / \mathrm{s}\right)\end{array}$ & $\begin{array}{c}\text { Specific conductance } \\
(\mathrm{S}) \\
(\mu \mathrm{S} / \mathrm{cm})\end{array}$ \\
\hline $\mathrm{D}$ & Big Creek & 37.4 & 28 \\
& Rush Creek & 4.88 & 68 \\
& & 1.51 & 28 \\
$\mathrm{C}$ & unmeasured inflow & 28.9 & 22 \\
& & 12.1 & 218 \\
$\mathrm{~B}$ & & & 18 \\
$\mathrm{~A}$ & & & 18 \\
\hline
\end{tabular}

${ }^{1}$ Calculated by:

$$
Q_{\text {unmeasuredinflow }}=Q_{d}-Q_{B i g C r}-Q_{\text {RushCr }}-Q_{c} \text {. }
$$

${ }^{2}$ Calculated by:

$$
S_{\text {unmeasuredinflow }}=\frac{(Q S)_{D}-(Q S)_{C}-(Q S)_{B i g C r}-(Q S)_{R u S h C r}}{Q_{\text {unmeasuredinflow }}}
$$

\section{GROUND WATER IN THE BILEDO MEADOW AREA}

\section{Geomorphology and Hydrogeologic Framework}

The Biledo Meadow area is outside of Yosemite National Park in the Sierra National Forest. Most Sierran meadows form when grasses and other flora become established in sediment-filled lakes in small closed basins. Flora in these meadows are sustained by water in the pore spaces of sediments recharged seasonally by precipitation and flow of streams into meadow basins.
Biledo Meadow is atypical of most Sierran meadows because it is not a closed basin. It slopes about $0.13 \mathrm{ft} / \mathrm{ft}(700 \mathrm{ft} / \mathrm{mi})$ to the south. The grasses, mosses, wild flowers, and other flora of Biledo Meadow and the springs in the area are sustained by a different, and unusual, hydrogeologic system.

The source of ground water in the Biledo Meadow area is precipitation, primarily melting snow and ice, that infiltrates the talus slopes, colluvium, and fractured rocks on the south side of Mount Raymond upslope from the meadow (fig. 24). Tahoe Till underlies Biledo Meadow and the surrounding area. Because the permeability of till usually is low, the Tahoe Till may contribute in 


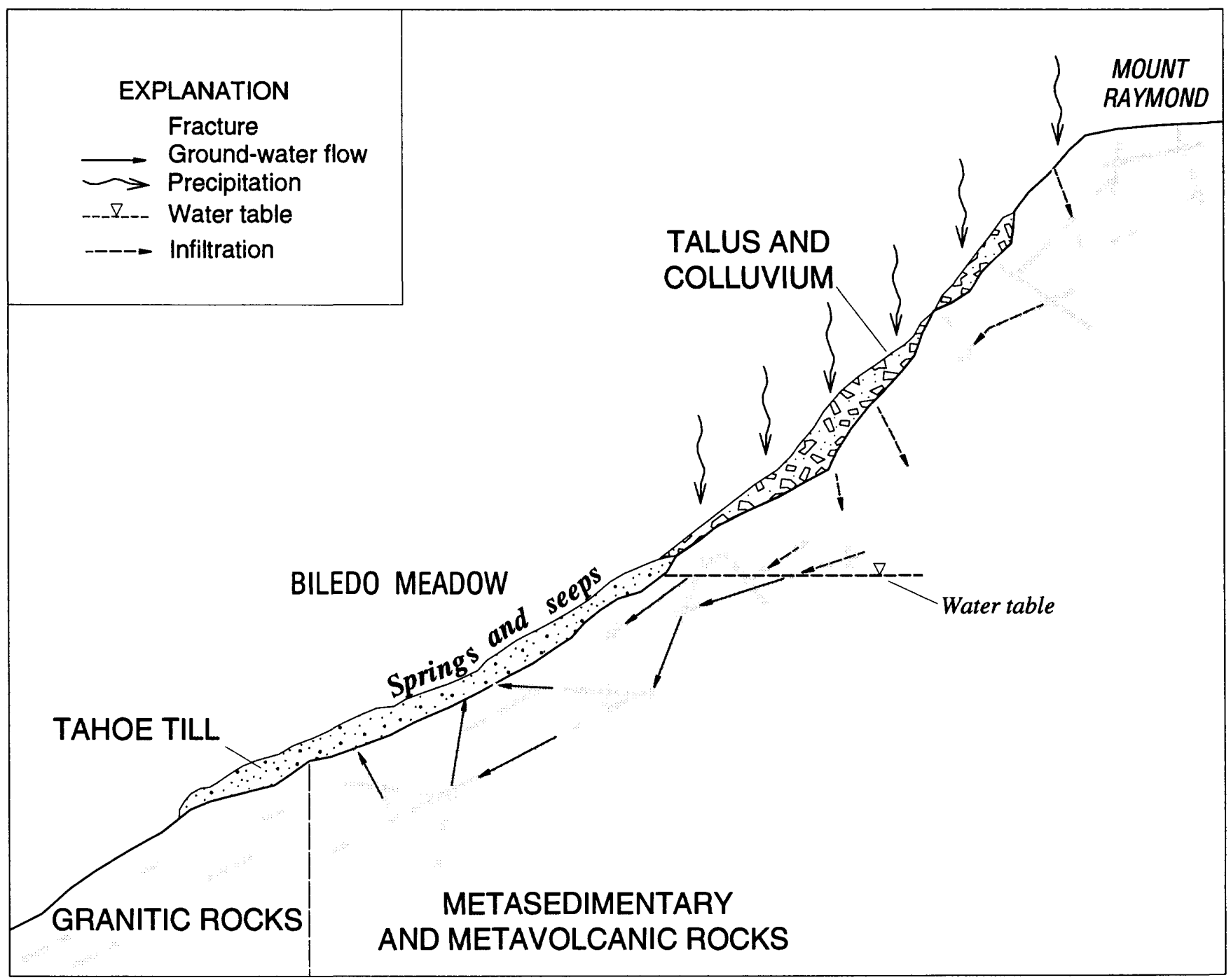

Figure 24. Conceptual model of ground-water flow in the Biledo Meadow area, Sierra National Forest, California.

confining ground water in the fractured rocks beneath the till by plugging fractures at the contact between till and bedrock. Three springs and numerous seeps discharge ground water through the till (figs. 24 and 25). Photographs of the excavations of the cisterns at Biledo Spring on July 26, 1931 (figs. 26 and 27), show spring flow emerging between boulders and cobbles in the Tahoe Till. Bryan and Taylor (1922) evaluated springs and seeps between Biledo Meadow and Mariposa Grove as sources of water for visitors' facilities at Mariposa Grove. They reported that Biledo Meadow springs 1 and 2 (fig. 25) "... rise from definite openings among boulders 1 to $2 \mathrm{ft}$ in diameter." The springs probably are located at points where ground water in fractures under a hydraulic head higher than land surface exited fractures and piped through the till. Having eroded the fine-grained till material, a permeable pathway was established through the remaining coarser grained material.

The aquifer supplying the springs in the Biledo Meadow area appears limited to the area overlain by Tahoe Till. Bryan and Taylor (1922) mapped small springs and intermittent seeps (not shown on any of the figures) outside the till-covered parts of the Rainier Creek basin between Biledo Meadow and Mariposa Grove. These springs and seeps, visited during a reconnaissance on April 9, 1992, discharge more dilute water (specific conductance 16 to $38 \mu \mathrm{S} / \mathrm{cm}$ ) than the three springs in the meadow area (specific conductance 165 to $187 \mu \mathrm{S} / \mathrm{cm}$ ). No springs were located in the Rainier Creek basin downstream from the Tahoe Till. This could indicate that ground water supplying the springs in the Biledo Meadow area is contained primarily in fractured metamorphic rocks that are not hydraulically well connected to granitic rocks in the lower part of the Rainier Creek basin (fig. 24). 


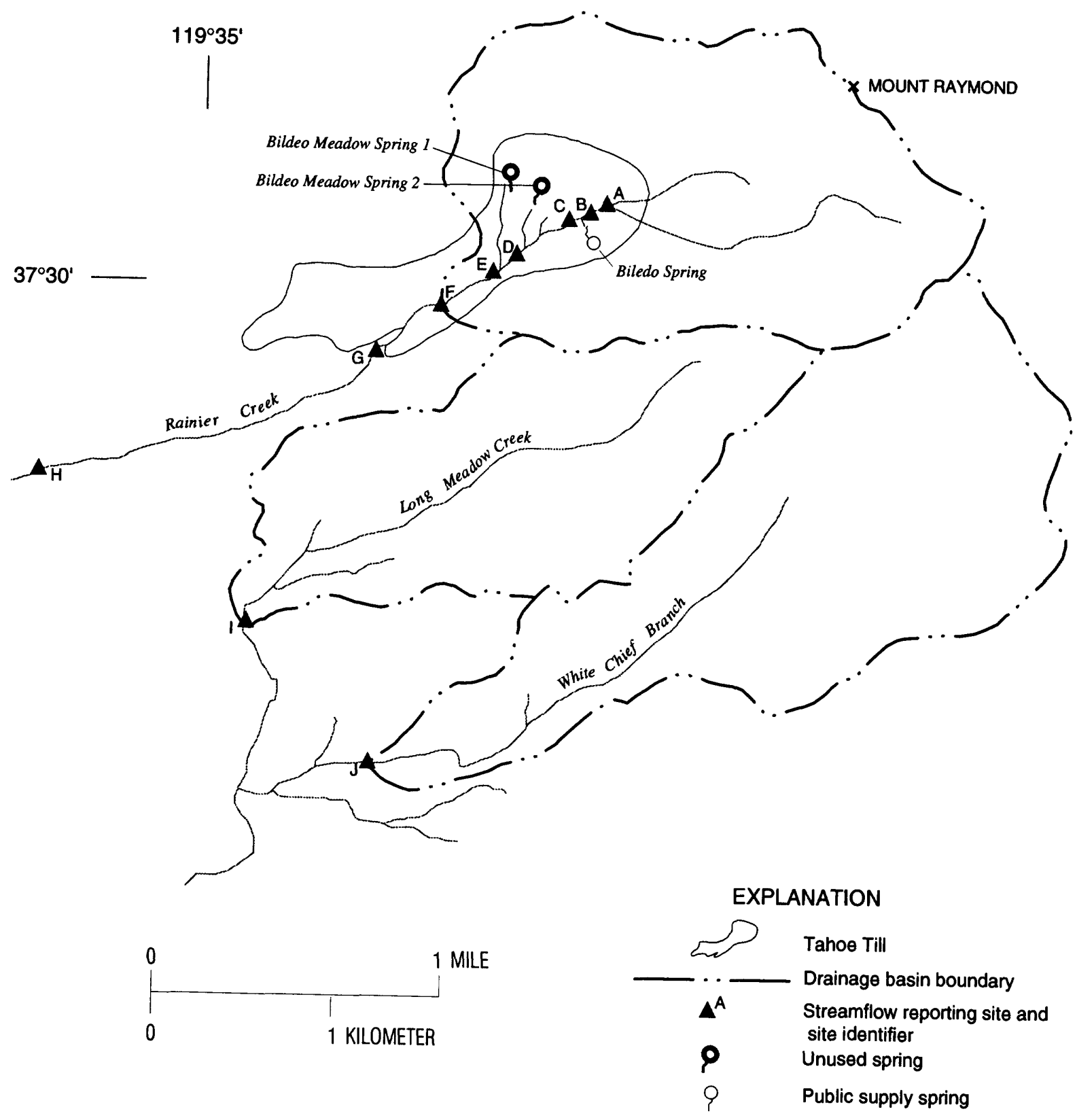

Figure 25. Location of springs and streamflow reporting sites in the Biledo Meadow area, Sierra National Forest, California.

The baseflow of Rainier Creek is higher than in nearby streams. Discharge comparisons between basins of unequal size is normalized by dividing stream discharge (in $\mathrm{ft}^{3} / \mathrm{s}$ ) by drainage area (in $\mathrm{mi}^{2}$ ) upstream of the discharge measurement point. For this report, normalized baseflow is termed basin yield. The yield of the Rainier Creek basin for the area above site $\mathrm{F}$ on figure 25 generally was more than an order of magnitude greater than the yield of the adjoining basins-Long Meadow Creek and White Chief Branch-and the South Fork Merced River at Wawona (table 5). The differences in basin yield are attributable to ground-water dis- charge from the unusual hydrogeologic environment near the headwaters of Rainier Creek.

\section{Spring Flow}

Flow from springs in the Biledo Meadow area was measured or estimated during gain-and-loss studies on Rainier Creek between July 1991 and October 1992 and intermittently at other times during the study (fig. 28A). Flow in the upper cistern of Biledo Spring was estimated using a culvert-rating method. (See appendix $\mathrm{C}$ for a more- 


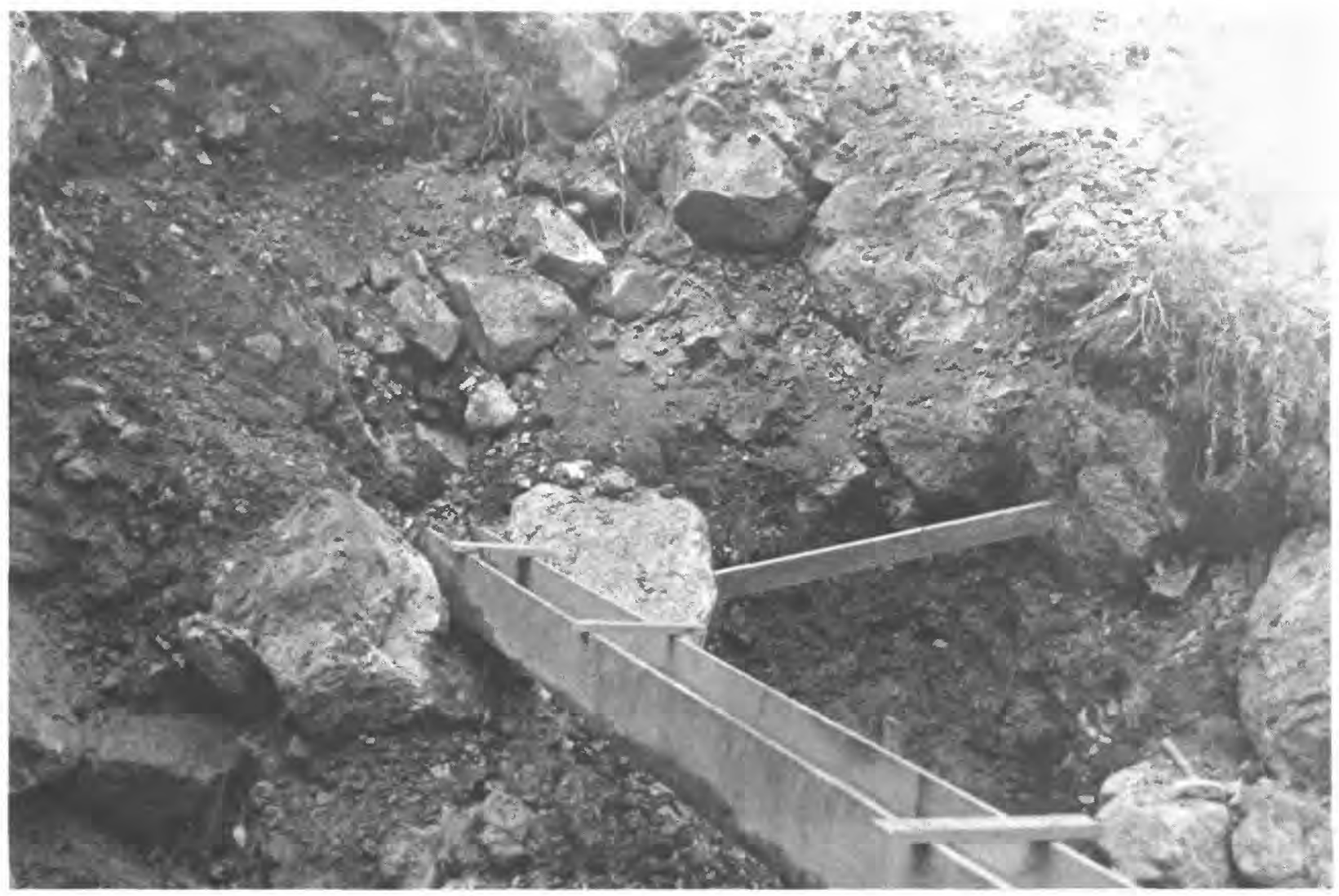

Figure 26. Excavation for the lower cistern at Biledo spring, Sierra National Forest, California, July 26, 1931. (Photographed by the National Park Service).

detailed description of this method.) Biledo Meadow springs 1 and 2 are unimproved freely draining springs. Biledo Meadow spring 2 was first measured following discovery of the spring during a gain-and-loss study on June 18, 1992.

Flow from Biledo Spring was relatively constant, varying only from 0.528 to $0.584 \mathrm{ft}^{3} / \mathrm{s}$ between July 1991 and October 1992 (fig. 28A). Generally, the rate of ground-water discharge from an aquifer is linearly proportional to the gradient of hydraulic head in the aquifer supplying the discharge. Hydraulic-head data are not available for the aquifer supplying Biledo Spring, but one would expect hydraulic head in the aquifer to decrease during the dry season which would result in decreased flow from the spring. The relatively constant flow from Biledo Spring could indicate either that hydraulic head in the aquifer does not change appreciably during the summer and autumn or that the flow rate is controlled by fracturerestricted discharge. If an aquifer is large and aquifer storage properties are high, a large volume of water could be supplied to a spring with only a small change in hydraulic head in the aquifer.
However, storage properties of fractured metamorphic and granitic rocks generally are low and the size of the aquifer supplying the spring likely is small (see "Relation to Flow in Rainier Creek" section). Some water in talus, colluvium, and till upslope of the Biledo Meadow area could drain to fractured rocks during the dry season, but probably does not provide recharge necessary to maintain hydraulic head during the dry season.

A linear relation between the discharge rate and the gradient of hydraulic head depends on laminar flow in the aquifer. If fracture aperture is small, the tortuosity of the flow path is large, and if the hydraulic-head gradient is high, turbulent flow may occur. Under these conditions, the discharge rate would be less sensitive to hydraulic-head changes in the aquifer, and, therefore, discharge would be relatively constant during times of turbulent flow. The relatively constant flow of Biledo Spring probably is caused by fractures that cannot transmit flows of more than about $0.7 \mathrm{ft}^{3} / \mathrm{s}$ regardless of the magnitude of hydraulic head.

On July 7, 1993, flow at Biledo Spring was estimated to be $0.674 \mathrm{ft}^{3} / \mathrm{s}$, which exceeds the 


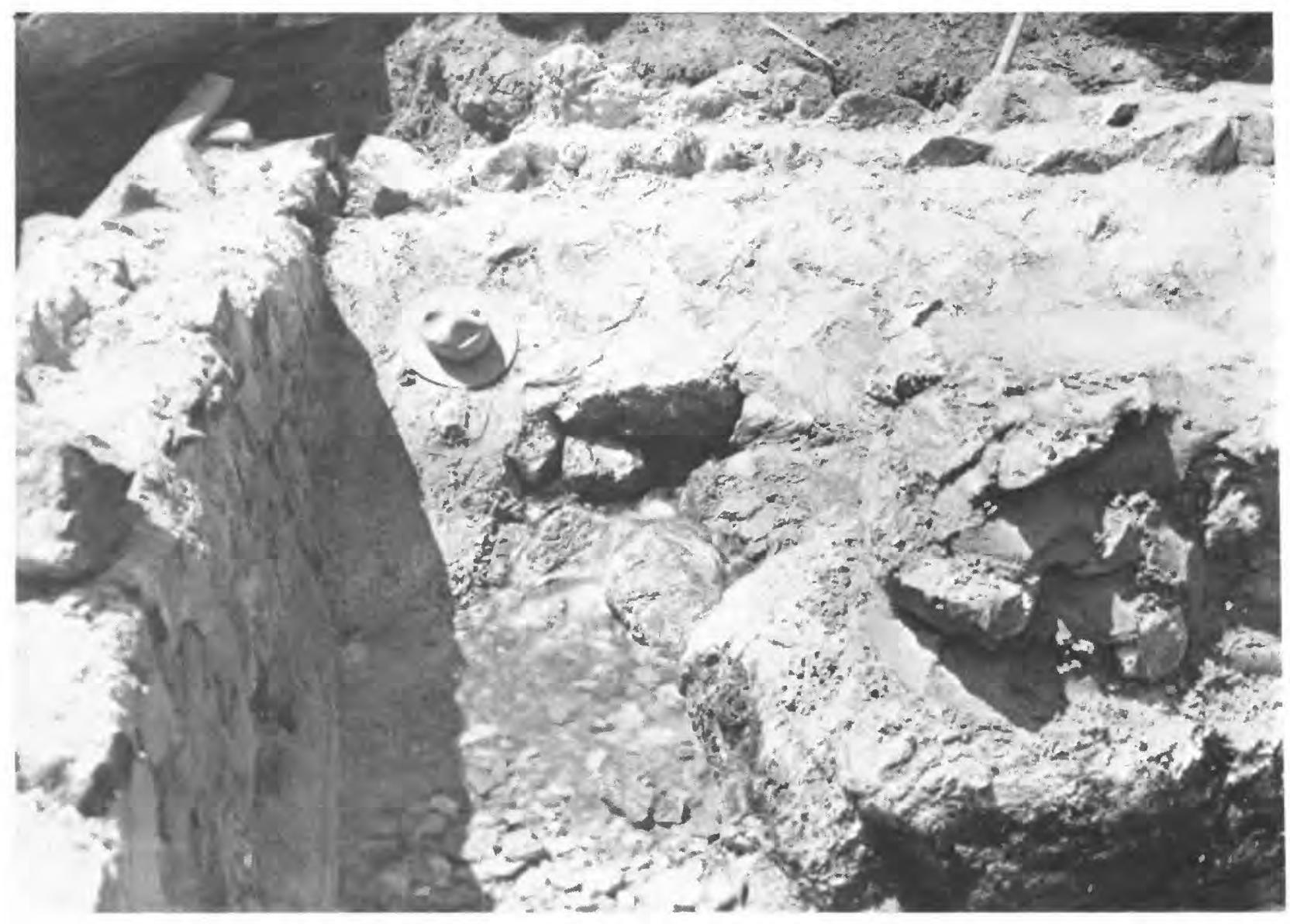

Figure 27. Excavation for the upper cistern at Biledo Spring, Sierra National Forest, California, July 26, 1931. (Photographed by the National Park Service).

Table 5. Basin yields for Rainier Creek, Long Meadow Creek, and White Chief Branch, Sierra National Forest, and for the South Fork Merced River at Wawona, Yosemite National Park, California

[See figures 20 and 25 for locations of basins and sites. $\mathrm{mi}^{2}$, square mile; --, no data]

\begin{tabular}{|c|c|c|c|c|}
\hline \multirow[b]{2}{*}{ Date } & \multicolumn{4}{|c|}{ Basin yield, in cubic foot per second per square mile } \\
\hline & $\begin{array}{c}\text { Rainer Creek } \\
\text { above } \\
\text { site F } \\
\text { (drainage area, } \\
\left.1.37 \mathrm{mi}^{2}\right)\end{array}$ & $\begin{array}{l}\text { Long Meadow } \\
\text { Creek above } \\
\text { site I } \\
\text { (drainage area, } \\
1.05 \mathrm{mi}^{2} \text { ) }\end{array}$ & $\begin{array}{c}\text { White Chief } \\
\text { Branch above } \\
\text { site J } \\
\text { (drainage area, } \\
1.43 \mathrm{mi}^{2} \text { ) }\end{array}$ & $\begin{array}{c}\text { South Fork } \\
\text { Merced River at } \\
\text { Wawona above } \\
\text { site C } \\
(\text { drainage area, } \\
99.2 \mathrm{mi}^{2} \text { ) }\end{array}$ \\
\hline $7-31-91$ & 1.31 & -- & -- & -- \\
\hline 8-01-91 & -- & - & -- & 0.080 \\
\hline $6-17-92$ & -- & -- & -- & .290 \\
\hline $6-18-92$ & 1.36 & - & -- & -- \\
\hline 8-04-92 & 1.12 & 0.019 & 0.168 & -- \\
\hline 8-05-92 & -- & -- & -- & .047 \\
\hline $10-07-92$ & .96 & .003 & .084 & -- \\
\hline $10-08-92$ & -- & -- & - & .019 \\
\hline
\end{tabular}



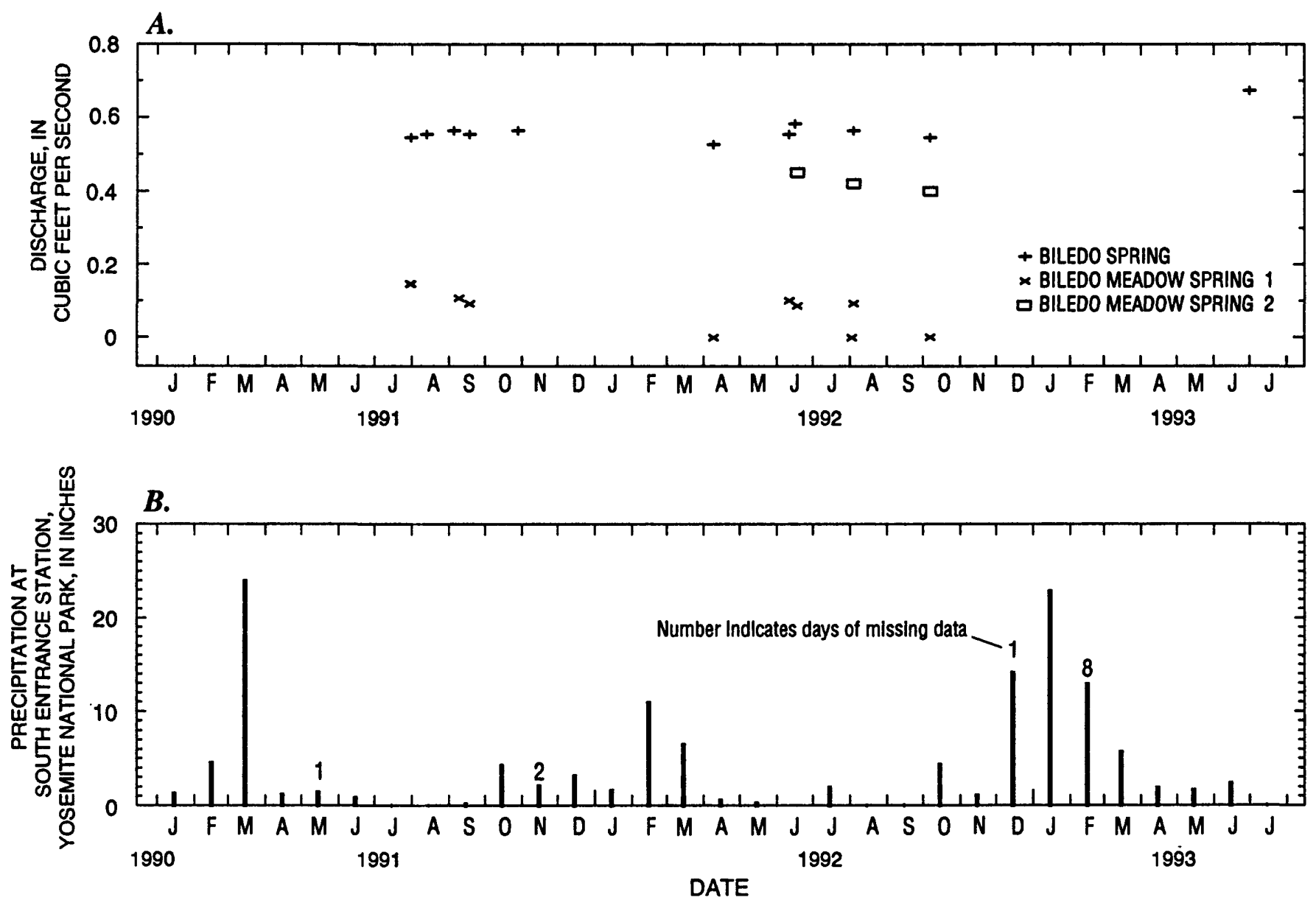

Figure 28. A. Discharge of Biledo Spring and Biledo Meadow springs 1 and 2, Sierra National Forest, and $B$. precipitation at the south entrance station at Yosemite National Park, California.

previously estimated highest flow by 15 percent and seems to cast doubt on the theory of hydraulically restricted fracture discharge. Precipitation during the winter of 1992-93 (fig. 28B) was much higher than precipitation during the previous 6 years, which were drought years in California. Increased recharge owing to increased precipitation may have raised hydraulic head in the aquifer and thus increased discharge of Biledo Spring. It is also possible that water draining from the Tahoe Till supplied some of the increased flow from the spring. Available data are insufficient to determine the relation between the timing and duration of precipitation and the amount of recharge to the spring and between hydraulic head in the aquifer and discharge of the spring.

Discharge from Biledo Meadow spring 1 is erratic. Early one morning in late July 1989 (prior to this study), the spring was dry but by afternoon the spring was flowing again (Larry Knapp, Proprietor of the Pack Station, oral commun., 1992). On April 9, 1992, even though snowmelt was flowing into the streams and discharging from marmot holes and seeps both upslope and downslope of Biledo Meadow, Biledo Meadow spring 1 was dry. On June 18, 1992, all three springs flowed normally. On August 4, 1992, at 10 a.m., Biledo Meadow spring 1 again was dry. A small fir seedling rooted in the loose sand and gravel at the bottom of the spring indicated that Biledo Meadow spring 1 probably had been dry long enough for a seed to germinate and the seedling to become established. By noon of that same day, Biledo Meadow spring 1 again flowed normally. On October 7, 1992, the spring was not flowing, but water in the spring rose $0.3 \mathrm{ft}$ in 10 minutes and then declined $0.2 \mathrm{ft}$ in a similar length of time.

Flow data for Biledo Meadow spring 2 are limited, but it appears that discharge from the spring is more variable than discharge from Biledo Spring (fig. 28A). Flow from Biledo Meadow spring 2 paralleled the trend of slightly decreasing discharge from Biledo Spring during the summer of 1992, which followed the relatively dry winter of 1991/92.

The cause of erratic flow from Biledo Meadow spring 1 is unknown nor is it known if similar 
phenomena have occurred at Biledo Spring or Biledo Meadow spring 2 . The generally more variable flow of Biledo Meadow springs 1 and 2 might be related to differences in hydraulic head at fracture discharge points. The altitude of Biledo Spring is about $60 \mathrm{ft}$ lower than Biledo Meadow spring 1 and about $54 \mathrm{ft}$ lower than Biledo Meadow spring 2 . If the fractures that supply the springs are part of a hydraulically connected network, then the difference in altitude of the springs indicates that hydraulic head in fractures supplying Biledo Meadow springs 1 and 2 is lower than hydraulic head in fractures supplying Biledo Spring. Discharge of ground water at the Biledo Meadow springs 1 and 2 might occur under laminar flow conditions and might reflect changing head conditions in the aquifer to a greater degree than discharge from Biledo Spring.

\section{Chemical Quality}

Ground water discharging from Biledo Spring and Biledo Meadow spring 1 is a dilute (specific conductance 181 and $165 \mu \mathrm{S} / \mathrm{cm}$, respectively, September 5, 1991, table 2) calcium bicarbonate water (fig. 13). Water from Rainier Creek, above Biledo Springs near Fish Camp, is chemically similar to water discharging from the springs (fig. 13), but more dilute (specific conductance $28 \mu \mathrm{S} / \mathrm{cm}$, September 5, 1991, table 2). The relatively small proportion of dissolved sodium and the absence of dissolved chloride indicate that the water from these springs does not contain any of the saline components detected in ground water from deep wells at Wawona. Water from these springs may have reacted primarily with metasedimentary or metavolcanic rocks, and talus and till deposits composed of these rocks, in the headwater area of Rainier Creek.

Stable isotope samples from the springs are enriched in deuterium relative to oxygen-18 and are shifted above the Santa Maria meteoric water line (fig. 16) on which data from most ground water sampled in the Wawona area lie. The stable isotopic composition of water from the springs reflects the isotopic shift often observed with snowmeltderived recharge (Carol Kendall, U.S. Geological Survey, oral commun., 1994). Ground water near Biledo Meadow probably is recharged when snowmelt infiltrates the talus and fractured rocks upstream of the Tahoe Till.

The tritium concentrations in samples collected in September 1991 were 12.4 and 9.1 TU for Biledo Spring and Biledo Meadow spring 1, respectively (table 3). These concentrations indicate that ground water from the springs originated as recharge after the early 1950's but not during the mid-1960's when atmospheric concentrations of tritium peaked (fig. 15).
Table 6. Dissolved ${ }^{222}$ radon in ground water in the Wawona area, Yosemite National Park and Sierra National Forest, California, 1992

[TH1, test hole 1; TH2, test hole 2. pC/L, picoCuries per liter]

\begin{tabular}{|c|c|c|}
\hline $\begin{array}{l}\text { State well } \\
\text { No., test } \\
\text { hole, or } \\
\text { spring }\end{array}$ & $\begin{array}{c}\text { Date of } \\
\text { sampling }\end{array}$ & $\begin{array}{l}\text { Dissolved } \\
{ }^{222} \text { radon, } \\
\text { total } \\
(\mathrm{pC} / \mathrm{L})\end{array}$ \\
\hline $\begin{array}{r}4 \mathrm{~S} / 21 \mathrm{E}-35 \mathrm{C} 1 \\
35 \mathrm{C} 8 \\
35 \mathrm{C} 13 \\
35 \mathrm{E} 17 \\
35 \mathrm{~F} 1 \\
35 \mathrm{G} 1 \\
35 \mathrm{G} 2 \\
35 \mathrm{H} 1 \\
35 \mathrm{H} 9 \\
35 \mathrm{M} 1 \\
35 \mathrm{P} 4 \\
35 \mathrm{R} 1 \\
36 \mathrm{M} 1\end{array}$ & $\begin{array}{l}7-27-92 \\
7-30-92 \\
7-30-92 \\
8-06-92 \\
7-30-92 \\
7-28-92 \\
7-28-92 \\
8-04-92 \\
8-04-92 \\
8-04-92 \\
8-03-92 \\
7-28-92 \\
7-28-92\end{array}$ & $\begin{array}{r}7,300 \\
8,800 \\
5,500 \\
4,100 \\
6,500 \\
2,200 \\
2,200 \\
12,000 \\
2,500 \\
3,600 \\
4,900 \\
5,100 \\
4,500\end{array}$ \\
\hline $\begin{array}{l}\text { TH1 }{ }^{1} \\
\text { TH }^{2}\end{array}$ & $\begin{array}{l}11-30-92 \\
11-30-92\end{array}$ & $\begin{array}{l}1,400 \\
2,500\end{array}$ \\
\hline $\begin{array}{l}\text { Biledo Spring } \\
\text { Biledo Meadow }\end{array}$ & $7-29-92$ & 420 \\
\hline $\begin{array}{l}\text { Spring } 1^{4} \\
\text { Biledo Meadow } \\
\text { Spring } 2^{5}\end{array}$ & $7-29-92$ & 490 \\
\hline
\end{tabular}

${ }^{1}$ State Well No. 4S/21E-35R1.

${ }^{2}$ State Well No. 4S/21E-35J2.

${ }^{3}$ State Spring No. 5S/22E-16AS1.

${ }^{4}$ State Spring No. 5S/22E-16BS1.

${ }^{5}$ State Spring No. 5S/22E-16BS2.

Water samples from Biledo Spring and Biledo Meadow spring 1 met drinking-water standards for inorganic constituents established by the U.S. Environmental Protection Agency and by the State of California (State of California, 1993). Data for inorganic constituents in water from both springs are published in Johnson and others (1991).

The concentrations of dissolved ${ }^{222}$ radon in Biledo Spring, Biledo Meadow spring 1, and Biledo Meadow spring 2, sampled on July 29, 1992, were 420,490 , and $370 \mathrm{pC} / \mathrm{L}$, respectively (table 6). These concentrations were much lower than the concentrations from well water at Wawona (median concentration 4,300 pC/L) and slightly exceeded the U.S. Environmental Protection Agency's proposed mean concentration level of $300 \mathrm{pC} / \mathrm{L}$ (State of California, 1993). Generally, the uranium content of metavolcanic rocks is lower than that of metasedimentary rocks, which in turn is lower than that 

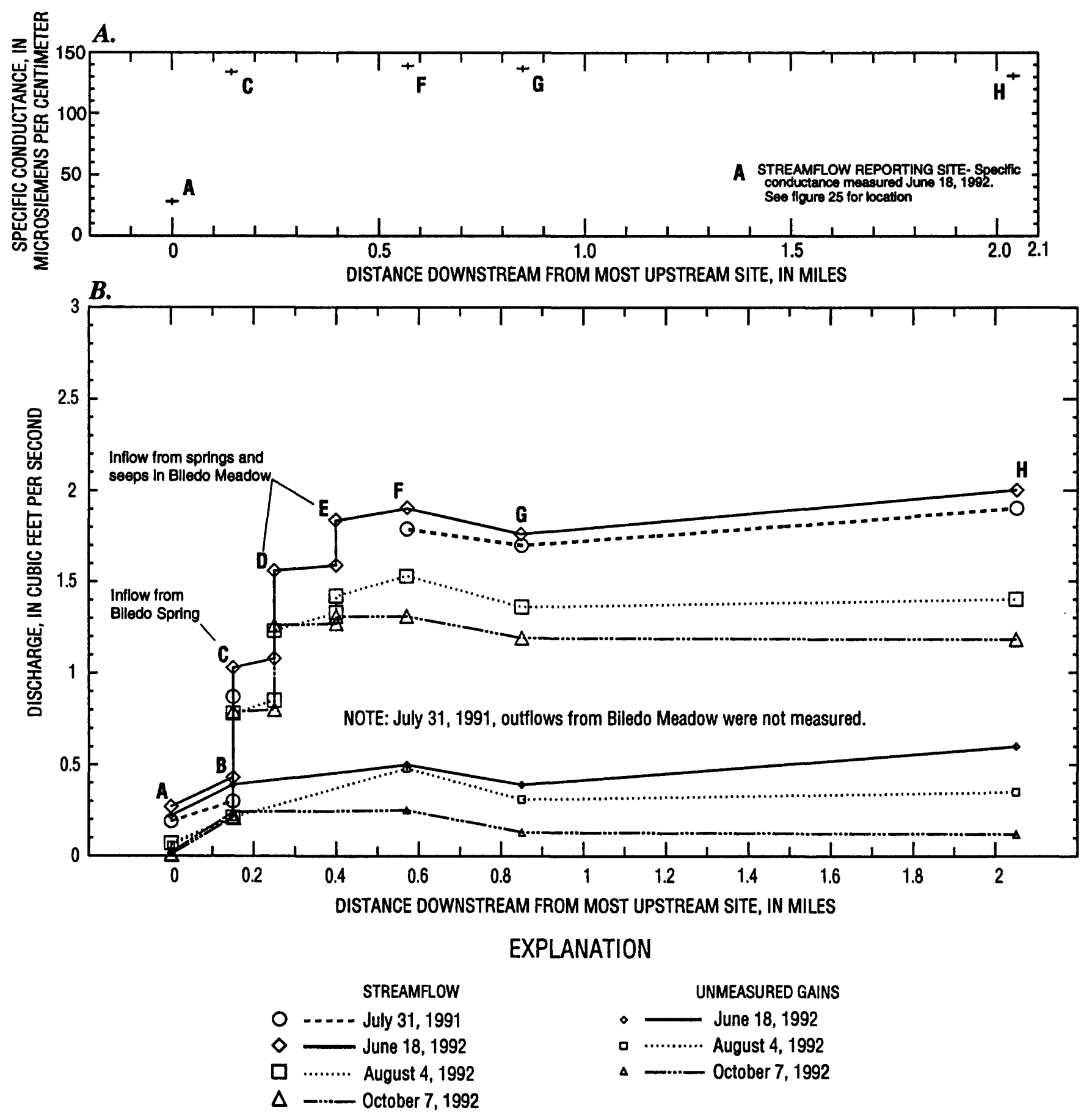

Figure 29. Specific conductance $A$. and discharge $B$. at streamflow reporting sites during the gain-and-loss studies on Rainier Creek, Sierra National Forest, California.

of granitic rocks in the Mount Raymond area (Sutley and others, 1983). The relatively low concentrations of dissolved ${ }^{222}$ radon probably reflect small amounts of uranium/thorium series minerals in the metamorphic rocks that store most of the ground water discharged at the springs.

No Giardia was detected in a sample taken from Biledo Spring on July 29, 1992.

\section{Relation to Flow in Rainier Creek}

Springs and seeps discharging through the Tahoe Till provide Rainier Creek with an unusually high baseflow. Most of the gains in flow in Rainier Creek occur in the area between sites A and F shown on figure $29 B$ where the Tahoe Till mantles fractured granitic, metasedimentary, and meta- 
morphic rocks. Streamflow and spring discharge measurements made during gain-and-loss studies on Rainier Creek are published in Mullen and others (1993). Streamflow in the creek increases in a stepwise fashion where outflow from Biledo Spring and small tributaries receiving discharge from Biledo Meadow springs 1 and 2 join the creek (fig. $29 B$ ). The uniform increase in streamflow at site C during each gain-and-loss study is due to the nearly constant discharge of Biledo Spring $\left(0.56 \mathrm{ft}^{3} / \mathrm{s}\right.$, fig. 28 ). The variable increase in streamflow at site $E$ is due to the varying discharge of Biledo Meadow spring 1.

Rainier Creek comes in contact with bedrock and colluvium between sites $F$ and $G$ on figure 25 . During the dry season, the creek loses between 5 and 10 percent $\left(0.09\right.$ to $0.17 \mathrm{ft}^{3} / \mathrm{s}$, fig. 29) of its flow to the ground-water system in this reach.

The gradual increase in flow of Rainier Creek is caused by ground-water discharge from small unmeasured seeps (fig. 29). When flow from point sources, such as springs and spring-fed tributaries, is subtracted from streamflow, the amount of seepage directly to Rainier Creek (diffuse seepage) can be seen (lower plot, fig. 29B). Most diffuse seepage to Rainier Creek is between sites $A$ and $F$ and is a much smaller component of the streamflow than measured spring discharge. This can be seen by comparing unmeasured flow gains in Rainier Creek to total streamflow for the same date (fig. 29B).

Specific conductance in Rainier Creek on June 18,1992 , increased dramatically between sites A and $C$ (26 and $134 \mu S / \mathrm{cm}$, respectively) and remained within 5 percent of $134 \mu \mathrm{S} / \mathrm{cm}$ between sites $\mathrm{C}$ and $\mathrm{H}$ (fig. 29A). The increase in specific conductance coincided with increased streamflow and provides further evidence that the streamflow increases in this reach primarily are due to discharge of ground water containing higher concentrations of dissolved solids than surface water.

Ground-water discharge from springs and seeps in the Biledo Meadow area to Rainier Creek (between sites $\mathrm{A}$ and $\mathrm{F}$ on figure 25) was calculated during four gain-and-loss studies (table 7). These studies were not done during winter or spring when ground-water discharge may have been higher. If we assume that ground-water discharges at a constant rate of about $1.60 \mathrm{ft}^{3} / \mathrm{s}$ between sites $\mathrm{A}$ and $\mathrm{F}$, total outflow from the ground-water system above site $\mathrm{F}$ would be about 50 million $\mathrm{ft}^{3} / \mathrm{yr}$. This is the equivalent of about 19 in. of recharge per year from precipitation to the Rainier Creek basin aquifer upstream of site $F$. The recharge area for this aquifer is the part of the drainage area above site $\mathrm{F}$ that is not covered by Tahoe Till (figs. 2 and 25). Recharge was calculated by distributing ground-water discharge $\left(50\right.$ million $\left.\mathrm{ft}^{3} / \mathrm{yr}\right)$ over the
Table 7. Total ground-water discharge from springs and seeps in the Biledo Meadow area to Rainier Creek, Sierra National Forest, California

[ft $\mathrm{ft}^{3} / \mathrm{s}$, cubic foot per second]

\begin{tabular}{cc}
\hline Date & $\begin{array}{c}\text { Discharge } \\
\left(\mathrm{ft}^{3} / \mathrm{s}\right)\end{array}$ \\
\hline $7-31-91$ & 1.60 \\
$6-18-92$ & 1.60 \\
$8-04-92$ & 1.46 \\
$10-07-92$ & 1.29 \\
\hline
\end{tabular}

1.17- $\mathrm{mi}^{2}$ recharge area. Total annual discharge from Biledo Spring is equivalent to about 7 in. of precipitation over the $1.17-\mathrm{mi}^{2}$ recharge area.

The above calculations do not imply that only $19 \mathrm{in}$. of recharge from precipitation are needed to sustain the average ground-water discharge of $1.60 \mathrm{ft}^{3} / \mathrm{s}$ to Rainier Creek or that only 7 in. of recharge from precipitation is needed to maintain flow from Biledo Spring. If precipitation is inadequate to sustain other basin outflows, such as sublimation of snow and ice, surface-water outflow, evapotranspiration, and ground-water underflow (if it occurs), ground-water discharge to Rainier Creek may decrease.

The flow constancy of Biledo Spring during the dry season of 1992, the sixth year of lower-thannormal precipitation, indicates that recharge during relatively dry years is adequate to sustain flow of the spring and probably other outflows from the ground-water system. It is likely that infiltrating snowmelt fills the available storage space in the aquifer early during snowmelt. Once storage space in the aquifer has been filled, the remaining melt water leaves the basin as streamflow. Because flow from Biledo Spring has been measured or estimated only intermittently, the flow characteristics of the spring cannot completely be evaluated until several years of continuous flow data have been compiled.

\section{WATER-SUPPLY ALTERNATIVES FOR WAWONA}

\section{South Fork Merced River}

The South Fork Merced River probably will continue to have very low flows in the summer and autumn. Unfortunately, the period of low streamflow coincides with increased demand for water owing to the seasonal increases in the number of employees, park visitors, and irrigation use.

Streamflow data for the South Fork Merced River at Wawona were collected continuously from 


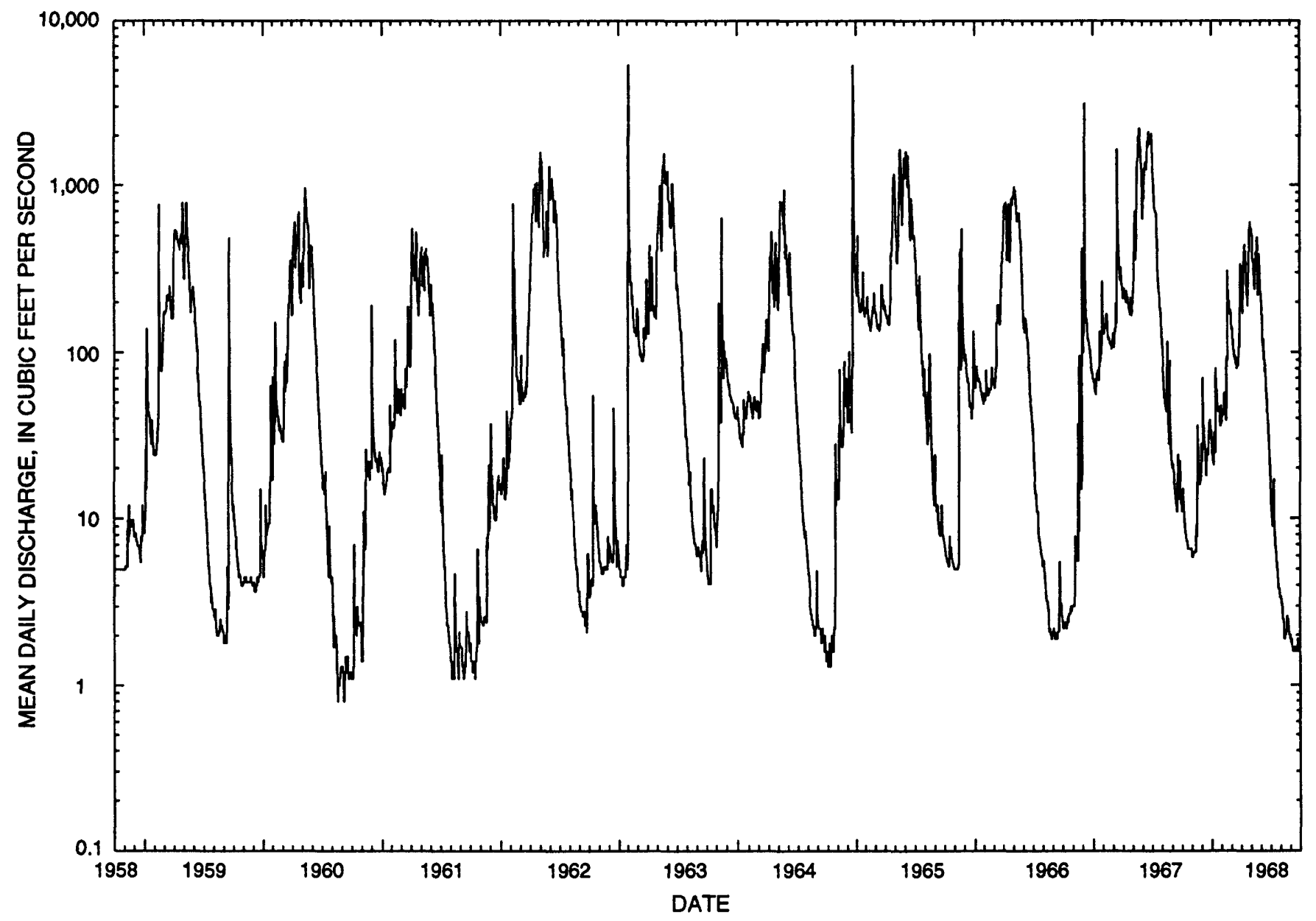

Figure 30. Mean daily discharge of the South Fork Merced River at Wawona, Yosemite National Park, California, October 1, 1958, to September 30, 1968.

October 1, 1958, through September 30, 1968. Mean daily discharge for this period is shown in (fig. 30). A graph showing streamflow frequency (fig. 31) for mean daily discharge for this period indicates that flows of less than $9 \mathrm{ft}^{3} / \mathrm{s}$ can be expected 30 percent of the time and flows of less than $2.3 \mathrm{ft}^{3} / \mathrm{s}$ can be expected about 10 percent of the time.

A graph showing streamflow frequency for August, September, and October, when flows are lowest, indicates that mean daily discharge of less than $10 \mathrm{ft}^{3} / \mathrm{s}$ during late summer and early autumn can be expected about 75 percent of the time (fig. 32). Flows of less $2 \mathrm{ft}^{3} / \mathrm{s}$ can be expected about 25 percent of the time.

Streamflow-frequency graphs for the South Fork Merced River (figs. 31 and 32) may not be appropriate for current water-resource planning purposes. Droughts during 1976-77 and 1987-92 are not represented by the data in these streamflowfrequency graphs; however, streamflow from 1958 to 1968 generally was lower than the long-term average (fig. 33). During 6 of 10 years represented by the streamflow-frequency graphs, mean annual flow of many Sierran streams was below mean discharge for the 1961-90 period, as indicated by the streamflow data for the Merced River at Pohono Bridge, an unregulated river with a long-term record for streamflow (fig. 33).

Flow in the South Fork Merced River during late summer and autumn is dependent on the timing of precipitation. Heavy spring snowfall and cold weather can significantly delay runoff and sustain flow in the South Fork Merced River during late summer. Below normal precipitation and an early thaw would have the opposite effect.

During winter and spring, very high flow can occur on the South Fork Merced River. Diversion, treatment, and storage of water from the South Fork Merced River during high-flow periods could alleviate stress on the aquatic environment by reducing dry season diversions. Between 1958 and 1968, streamflow exceeded $100 \mathrm{ft}^{3} / \mathrm{s}$ about 35 percent of the time (fig. 31). Assuming that a person requires $100 \mathrm{gal} / \mathrm{d}$, if $1.42 \mathrm{ft}^{3} / \mathrm{s}$ of water was diverted from the South Fork Merced River for 1 day during the 


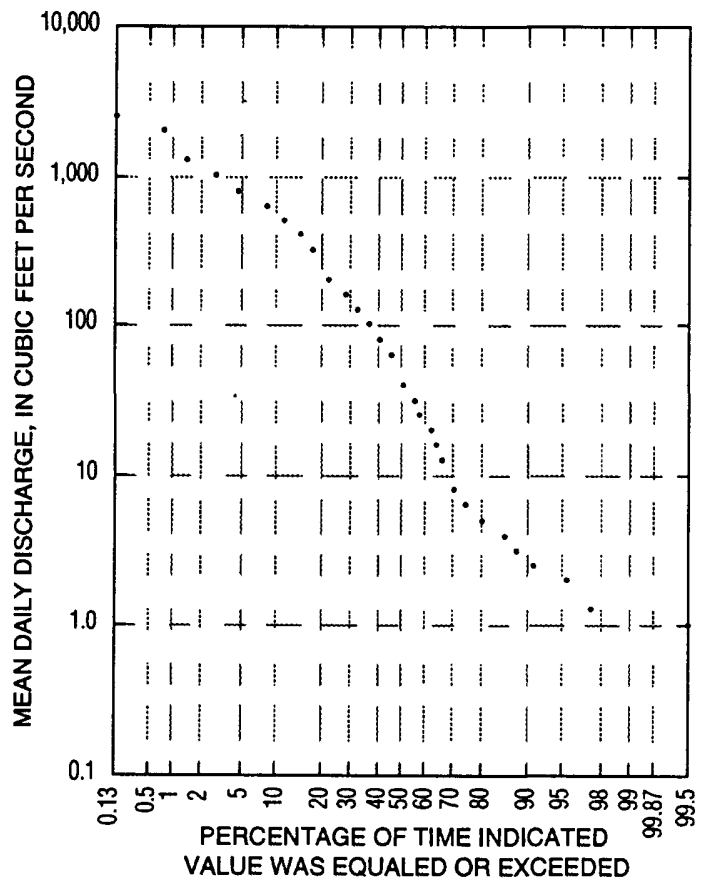

Figure 31. Streamflow frequency for the South Fork Merced River at Wawona, Yosemite National Park, California, for the period of continuous streamflow measurement, October 1, 1958, to September 30, 1968.

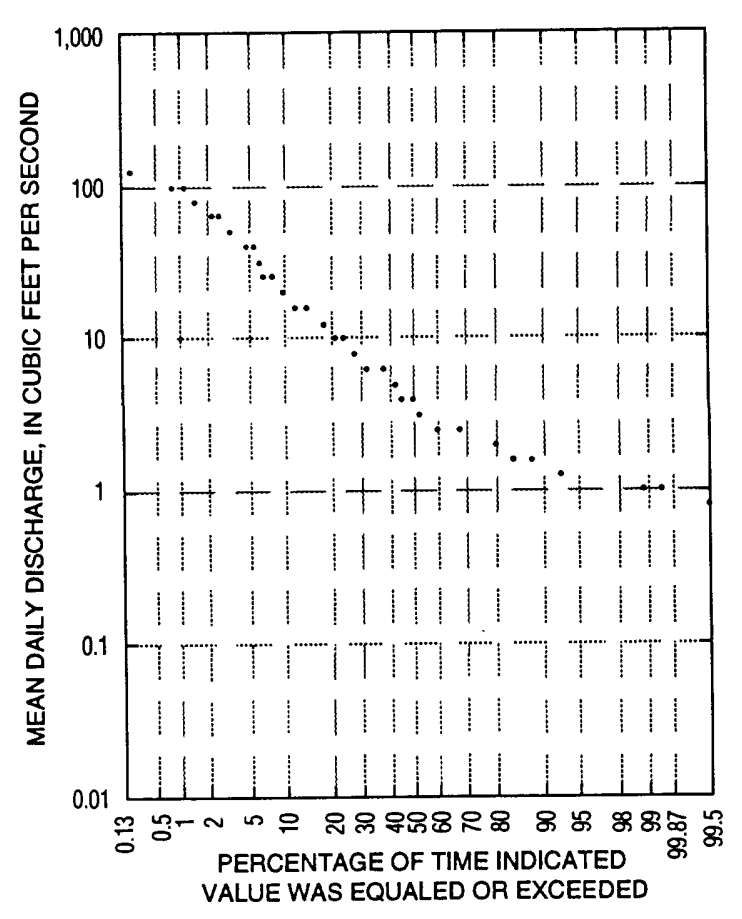

Figure 32. Streamflow frequency for the South Fol Merced River at Wawona, Yosemite National Park California, for the months of August, September, an October between October 1, 1958, and September 3C 1968.

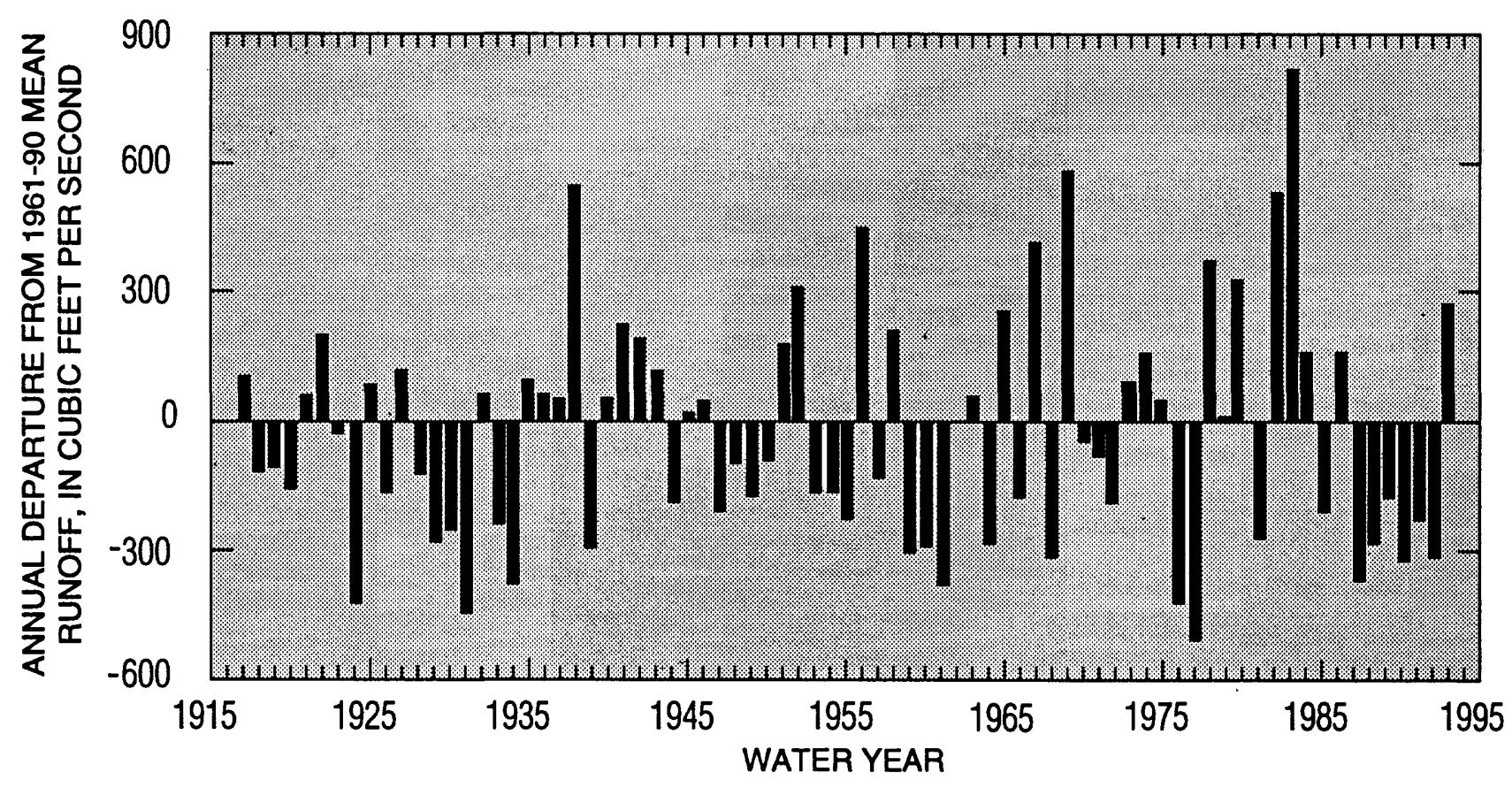

Figure 33. Annual departure from the 1961-90 mean discharge for the Merced River at Pohono Bridge, Yosemite National Park, California. 
spring, the river could provide enough water to supply 100 people during August, September, and October. The South Fork Merced River could provide this amount of water if a 1-million gallon tank were available for storage.

\section{Ground Water in the South Fork Merced River Valley}

Ground water from fractured granitic rocks in the South Fork Merced River valley would not be the most reliable source of good quality water for future water needs in Wawona. However, this source could be used to augment other sources of water. Approximately 100 wells in Wawona currently supply about 265 private residences, a store, and children's camp.

To meet the water-supply demands in Wawona, wells would need to produce a continuous flow of 7 $\mathrm{gal} / \mathrm{min}$ to supply 100 people, assuming that each person uses $100 \mathrm{gal} / \mathrm{d}$. Short-term pumping tests on 42 domestic wells in Wawona indicate that the median yield of wells is less than $5 \mathrm{gal} / \mathrm{min}$. Investigations by Swanson (1979) and Schmidt (1977; consultant, written commun., 1994) indicate that well yields estimated from short-term pumping tests are not reliable for long-term production and that continuously pumped production wells probably will experience drastic decreases in yield during the dry season. Median yield of wells in Wawona probably would decrease to substantially less than 5 $\mathrm{gal} / \mathrm{min}$ if pumped continuously.

In Wawona, it has been difficult to use standard geologic techniques to select sites for highly productive wells. Seismic refraction techniques were unsuccessful in locating high-yielding wells during a study by Franks (consultant, written commun., 1983). Fracture-trace mapping for well location purposes is difficult because fractures are not visible beneath alluvium, till, and soils that overlie the fractured granitic rocks at Wawona. Additionally, high-yielding wells do not seem to be located near the few fracture traces that could be mapped in the valley floor.

A comparison of short-term well yield and well depth indicates that many high-yielding wells are shallow (fig. 19). The high yield of the shallow wells indicates that the wells encountered open fractures near land surface. Wells that did not intersect open fractures near land surface were drilled deeper to provide the well with cisternlike storage for ground water flowing through deeper, lower yielding fractures. California water-well standards, enforced by the Mariposa County Health
Department, require community water-supply wells to be constructed with a grouted annular seal that extends from land surface to at least $50 \mathrm{ft}$ below land surface. Domestic wells, such as the wells used to provide most of the well-yield data for this study, are required to have a grouted annular seal of at least $20 \mathrm{ft}$. The deeper grouted annular seal required for community supply wells would seal the wells from shallow fractures that may be open and transmissive.

Ground water from deep flowing wells (with depths deeper than $350 \mathrm{ft}$ and located on the valley floor) contains sodium and chloride as the dominant dissolved species. Dissolved solids increased by more than 50 percent in water flowing from the two deep test wells drilled in the valley floor. After a 5-month flow test, the discharge rate of water flowing from TH2 dropped from 90 to about 25 $\mathrm{gal} / \mathrm{min}$. At the same time, specific conductance increased from about $350 \mu \mathrm{S} / \mathrm{cm}$ to probably more than $600 \mu \mathrm{S} / \mathrm{cm}$ (June 1993 measurement, fig. 34). Prior to drilling $\mathrm{TH} 2$, hydraulic head in the deep pressurized fractures was about $150 \mathrm{ft}$ above land surface. Hydraulic head in this test hole was estimated from well-head pressures at nearby private wells that were constructed similarly to $\mathrm{TH} 2$.

Hydraulic head at TH2 and at nearby deep wells was less than $20 \mathrm{ft}$ above land surface at the end of the flow test. The decrease in hydraulic head during the 5-month flow test apparently allowed deeper, more saline water to migrate upward and become a larger proportion of well discharge. Installation of pneumatic packers in January 1992 and a permanent grouted seal $230 \mathrm{ft}$ below land surface in July 1993, allowed the hydraulic head to increase and presumably began to force the moremineralized ground water to greater depths as indicated by the lower specific conductance on October 26, 1993 (fig. 34). Flow from TH1 during this same period dropped from 30 to $0 \mathrm{gal} / \mathrm{min}$ and specific conductance increased from 1,520 to $2,350 \mu \mathrm{S} / \mathrm{cm}$ (table 2). The chemical content of ground water from early and late in the flow test periods for both test wells is shown in figure 13 and table 2.

Additional development of ground water in the South Fork Merced River valley could result in degradation in the quality of ground water in deep fractures and allow saline water to flow up wellbores and mix with shallow freshwater. The use of deep wells during the summer and autumn dry seasons when hydraulic heads in shallow fractures are at their seasonal lows could exacerbate the water-quality problem.

All well waters sampled in the South Fork Merced River valley greatly exceeded the U.S. Environmental Protection Agency's recommended 


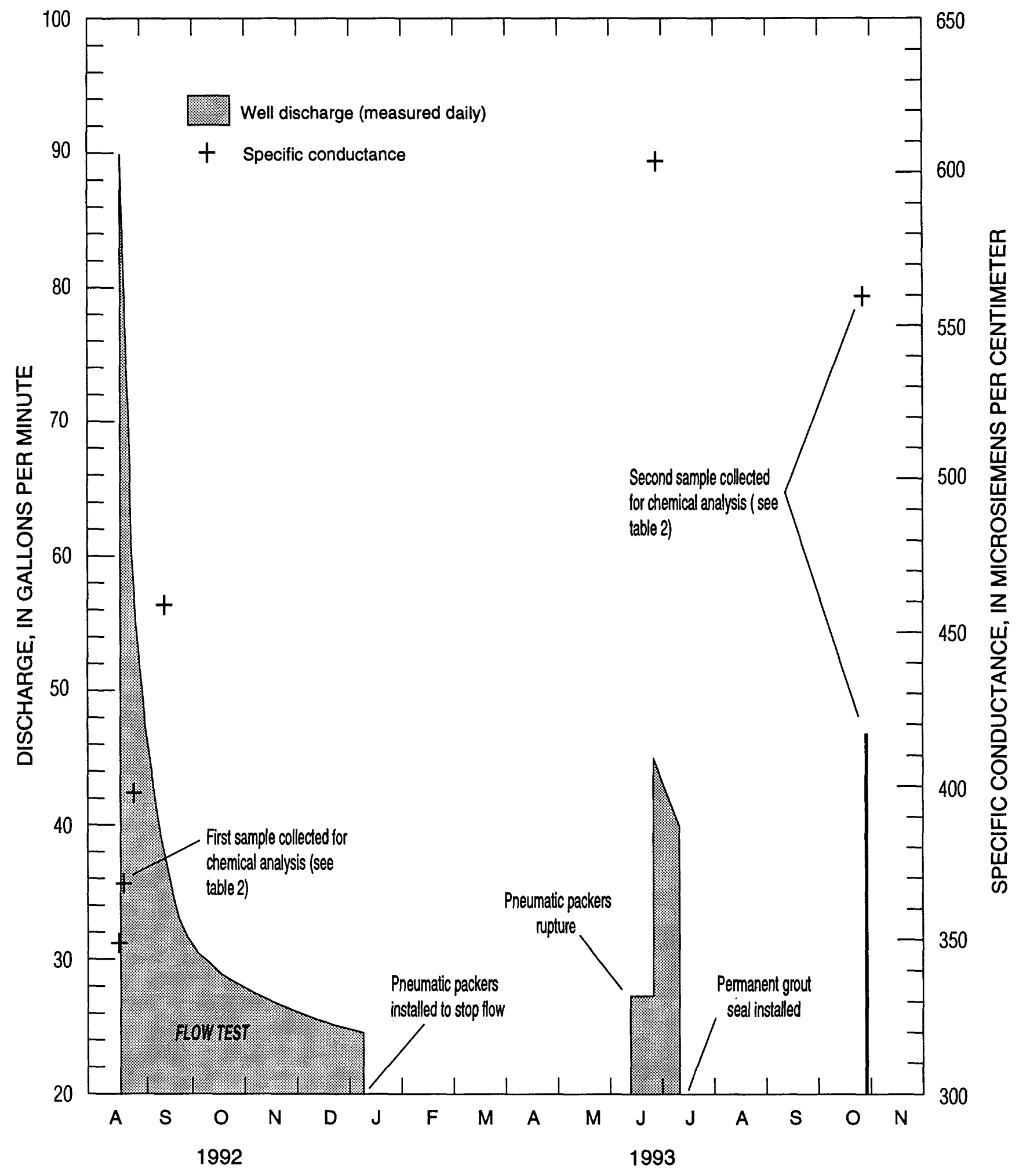

Figure 34. Variation of well discharge and specific conductance during and after the flow test at test hole 2 (TH2), Yosemite National Park, California. 
mean concentration for dissolved ${ }^{222}$ radon (median value 4,300 pC/L) (State of California, 1993). The high levels of dissolved ${ }^{222}$ radon reflect the presence of uranium/thorium series minerals in granitic rocks in the underlying aquifer. Radon is a carcinogen that can be removed from water by aeration or activated carbon filtration units. Construction of aeration units or other facilities would be necessary if this ground-water source is developed.

Ground water in some wells in the South Fork Merced River valley exceeds the secondary drinking-water standards for dissolved iron $(0.3$ $\mathrm{mg} / \mathrm{L})($ State of California, 1993). One well had a very noticeable iron-bacteria problem. Other wells do not exceed secondary drinking-water standards, but do have relatively high concentrations of dissolved iron and manganese. Dissolved iron and manganese usually do not cause health problems; however, they do cause taste and aesthetic problems, and therefore the water possibly would have to be treated to remove these substances.

Finally, significant increases in ground-water pumping in the South Fork Merced River valley could divert water that otherwise would discharge into the South Fork Merced River. Streamflow gains and losses measured on this river during the dry season never exceeded the measurement error for each of the methods used. However, gain-andloss studies indicate that the South Fork Merced River generally loses flow between the diversion dam upstream of Wawona and the State Route 41 bridge at Wawona and then appears to gain flow downstream of the State Route 41 bridge. Part of this downstream gain probably comes from shallow ground water or soil water discharging into the tributaries. During the gain-and-loss studies, water was flowing in upstream reaches of some tributaries, but these reaches were dry where they joined the South Fork Merced River. Water from the tributaries may infiltrate the coarse alluvium of the South Fork Merced River valley and then reemerge downstream of the State Route 41 bridge. Pumping of wells could divert water that otherwise would join the river.

Interaction between streamflow and ground water has been examined only synoptically. The amount of ground water diverted from the South Fork Merced River by existing wells in Wawona is a small part of the water budget for this river basin. Additional wells could result in ground water being diverted from its normal flow paths and from current discharge locations at other wells, streams, springs or seeps, and vegetation. The effects of additional pumping cannot be predicted without significantly more information on the properties, boundaries, and water budgets of aquifers in the valley.

\section{Biledo Spring}

Biledo Spring represents the most probable source of reliable, good-quality water for Wawona. The rate of discharge from this spring, measured intermittently during the summers of 1991 and 1992 , was nearly constant at about $250 \mathrm{gal} / \mathrm{min}$ $\left(0.56 \mathrm{ft}^{3} / \mathrm{s}\right.$, fig. 28). The source of water for the spring is primarily high-altitude snowmelt. Annual discharge from Biledo Spring is equivalent to about $7 \mathrm{in.}$ of precipitation in the recharge area of the aquifer in the Biledo Meadow area. Annual discharge of ground water to Rainier Creek in the Biledo Meadow area is equivalent to about 19 in. of precipitation in the recharge area of the aquifer in that area. Because average precipitation in the Biledo Spring area is between 50 and 60 in. per year (Rantz, 1969), the fracture system supplying water to the springs and seeps probably is fully recharged each year. The water is dilute (specific conductance, $181 \mu \mathrm{S} / \mathrm{cm}$ ) and contains no trace elements in concentrations that exceed primary drinking-water standards (State of California, 1993). On July 29, 1992, the concentration of dissolved ${ }^{222}$ radon at Biledo Spring was $420 \mathrm{pC} / \mathrm{L}$ (table 6), which was much lower than the concentration in ground water in the granitic rocks of the South Fork Merced River valley at Wawona, which had a median value of $4,500 \mathrm{pC} / \mathrm{L}$. No Giardia was detected in a sample taken on July 29, 1992.

If Biledo Spring is used as an alternate source of water supply for Wawona, the flow of Rainier Creek will be reduced by an amount equivalent to the diversion. This diversion, however, is not expected to drastically affect Rainier Creek because the combined discharge from other springs and seeps in the Biledo Meadow area exceeds flow from Biledo Spring.

Discharge has not been measured continuously for any of the springs in the Biledo Meadow area. Biledo Meadow spring 1 has been observed to fluctuate cyclically and occasionally to go dry. Intermittent flow from Biledo Meadow spring 1 raises concerns about the flow constancy of Biledo Spring. Before the long-term reliability of Biledo Spring as a source of supply can be assessed, spring discharge data would need to be collected over several years. No data are available on the temporal variability of water quality in Biledo Spring. To assess long-term water-quality variability, it could be resampled for several years for chemical and isotopic constituents. If Biledo Spring were sampled for clorofluorocarbons and dissolved gases several times a year for many years, data from the sampling could be used to determine the retention time of water in the aquifer and to provide information on the hydraulic characteristics of the 


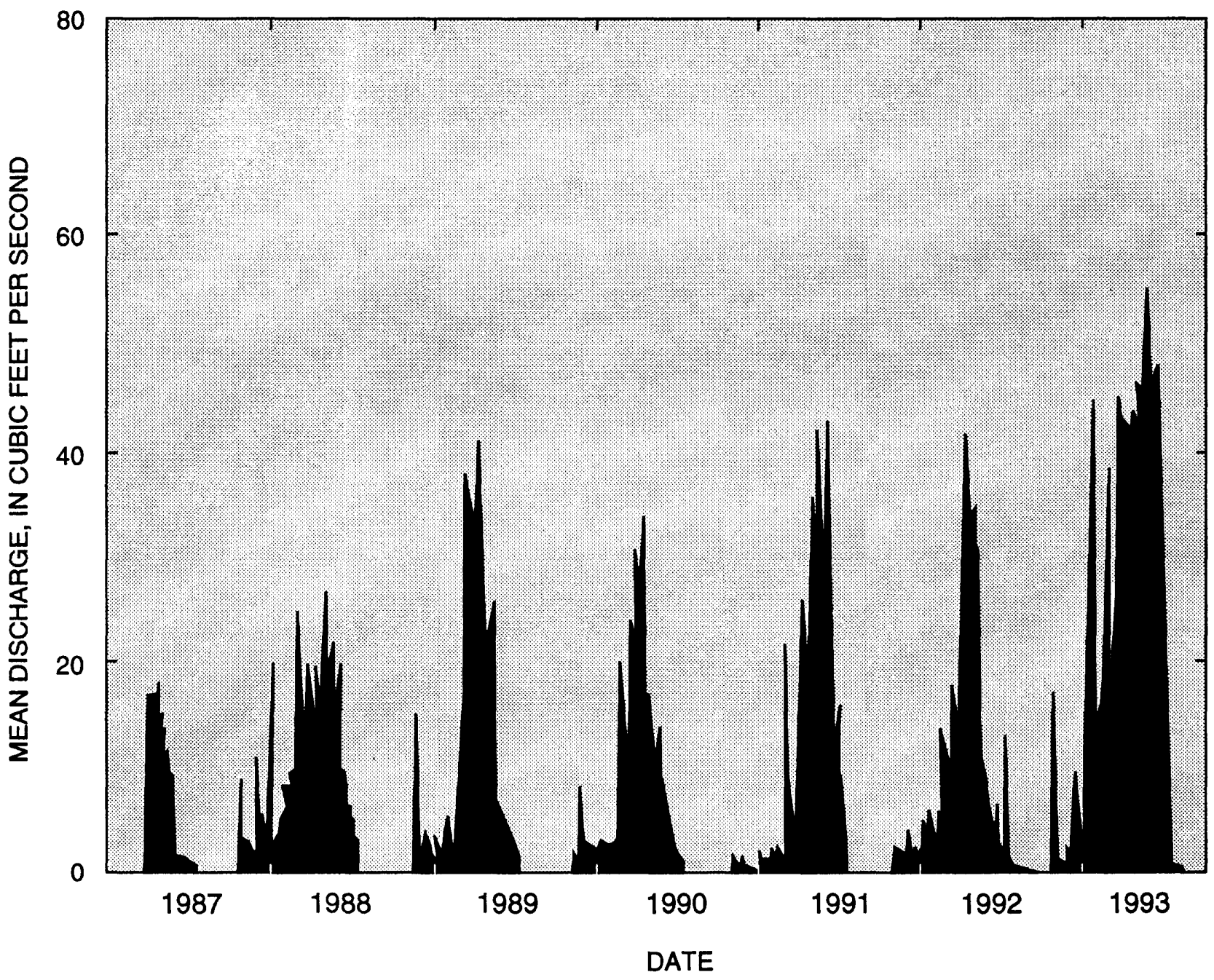

Figure 35. Mean daily discharge diverted from Big Creek by the Madera Irrigation District (station no. 11267350), Sierra National Forest, California, 1987-93.

aquifer. This information would help planners assess the long-term reliability of Biledo Spring as a source of water for Wawona.

Biledo Spring supplies water to Mariposa Grove and the south entrance station of Yosemite National Park through a pipeline constructed in 1932. Water from Biledo Spring could be brought to Wawona by laying about $4 \mathrm{mi}$ of pipeline along State Route 41 between the south entrance station and Wawona or by diverting Biledo Spring water from Big Creek near the confluence with the South Fork Merced River. With appropriate regulatory approval, water diverted near the mouth of Big Creek could be substituted for water withdrawn from Biledo Spring. Diverting water from Big Creek would not disturb the ecosystem of the Rainier Creek or Big Creek basins; however, it would reduce flow of the South Fork Merced River by an amount equal to the water diverted. This water could be treated at existing facilities in Wawona prior to distribution by the National Park Service water system.

Several public and private entities have appropriative rights to water in Big Creek. The Madera Irrigation District diverts water from Big Creek downstream of the mouth of Rainier Creek near Fish Camp, which is south of the study area. The mean daily discharge of the diversion by the Madera Irrigation District is shown on figure 35. The diversions, which are used to fill downstream reservoirs, occur primarily during the high-runoff period between April and June. Water-rights issues involved in substituting a diversion from Big Creek for a diversion from Biledo Spring have not been investigated. 


\section{SUMMARY}

Wawona, near the south entrance station in Yosemite National Park, is one of several potential relocation sites for park administrative facilities and concessionaire and employee housing. The source of water for the National Park Service water distribution system at Wawona is the South Fork Merced River. The river, however, does not adequately meet the water-supply needs of existing facilities in Wawona during late summer and autumn. Because of the limited water supply from the river, most private residences in Wawona are supplied by ground water from private wells. Three potential sources of water for future water-supply needs in the Wawona area are (1) the South Fork Merced River, (2) the fractured granitic rocks beneath Wawona, and (3) Biledo Spring near the headwaters of Rainier Creek in the Sierra National Forest. Unconsolidated deposits of alluvium and glacial till at Wawona contain little useable water.

The South Fork Merced River, the current source of water for the National Park Service water system, is dilute and of good quality. A modern water-treatment plant provides filtered, chlorinated water to the park's water system. Flow in the river is dependent on the amount and timing of precipitation in the river basin and on the temperature at higher elevations where the snowpack accumulates. Although the river does not adequately meet watersupply needs of existing facilities at Wawona during late summer and autumn, the river could be relied on to produce additional water if facilities were constructed to divert and store water during high-flow periods for use later in the year.

Ground-water flow in the fractured granitic rocks beneath Wawona is partly controlled by pressures within the earth (in situ stress) that can squeeze fractures closed or allow them to be open and permeable. The relation between in situ stress and the orientation of fractures in the two test holes drilled for the study indicates that fractures within a few hundred feet of land surface in the valley floor may be poorly connected to fractures deeper beneath the valley. As a result, ground water is segregated vertically into a local, shallow flow system and a deeper flow system with undetermined boundaries.

Ground water in the local, shallow flow system probably does not circulate deeper than about $250 \mathrm{ft}$ below land surface. Ground water in shallow fractured rocks flows from adjacent hillsides toward the valley, although the South Fork Merced River at Wawona does not gain appreciable flow from the ground-water-flow system during the dry season. Yields of shallow wells range from about 0.1 $\mathrm{gal} / \mathrm{min}$ to $19 \mathrm{gal} / \mathrm{min}$ (median yield $5 \mathrm{gal} / \mathrm{min}$ ). Shallow ground water is a dilute, calcium sodium bicarbonate water that results from chemical weathering of minerals in granitic rocks. The chemical quality of shallow ground water generally is good, but concentrations of dissolved iron and manganese do cause aesthetic problems, such as staining of kitchen and bathroom fixtures. Dissolved ${ }^{222}$ radon, a naturally occurring gas, greatly exceeded the proposed primary drinking-water standard of $300 \mathrm{pC} / \mathrm{L}$. Dissolved ${ }^{222}$ radon, which damages lung tissue, is carcinogenic. Tritium concentrations indicate that shallow ground water originated as precipitation probably after the testing of atmospheric nuclear devices stopped in the 1960's.

The deep flowing wells and two test holes drilled in the valley floor intersect deep fractures containing ground water under hydraulic head as high as $160 \mathrm{ft}$ above land surface. When first constructed, the deep wells flowed at rates as high as $100 \mathrm{gal} / \mathrm{min}$. Ground water from these wells is a sodium calcium chloride water and is more mineralized than ground water from the shallow wells. The source of chloride and associated cations in water from these wells could be from upward leakage of deep saline water of unknown origin or from leaching of saline-fluid inclusions in the granitic rocks by ground water. Water flowing from the deepest well in the valley floor, TH1, exceeds the secondary maximum contaminant level for dissolved solids. Dissolved ${ }^{222}$ radon concentrations exceed the proposed primary drinking-water standard of $300 \mathrm{pC} / \mathrm{L}$. The absence of tritium indicates that recharge of ground water in the deep fractures occurred prior to the start of atmospheric nuclear testing in the 1950's. Stable-isotope data indicate that the water may have originated as precipitation during a climatically cooler period thousands of years ago or as precipitation between 1,400 and $3,700 \mathrm{ft}$ higher in altitude than precipitation that recharged the shallow flow system. The deep wells allow the chloride-dominated, deep ground water to flow up wellbores and invade shallow fractures.

Currently, about 100 privately owned wells drilled in the fractured granitic rocks supply water to Wawona residents. Additional ground water could be developed from the shallow and deep flow systems, but other sources of water would probably be more reliable. Traditional methods (fracturetrace mapping and seismic geophysics) of locating sites that would produce high-yielding wells have not been successful at Wawona. High-yielding wells are not common in this area. Well yields, estimated from short-term pumping tests in nonflowing wells, are low (median yield about 5 $\mathrm{gal} / \mathrm{min}$ ) and probably would not be sustained during long-term pumping. Short-term yield should not be relied on for planning purposes. Developing water from deep flowing wells may be even less 
reliable. During long-term flow tests, discharge dropped from 90 to $25 \mathrm{gal} / \mathrm{min}$ and from 30 to 0 $\mathrm{gal} / \mathrm{min}$ at $\mathrm{TH} 2$ and $\mathrm{TH} 1$, respectively. At both test holes, decreases in flow rates were coincident with increases of greater than 50 percent in dissolvedsolids concentrations. Ground water would need to be treated to remove dissolved ${ }^{222}$ radon.

Data collected during this study indicate that Biledo Spring could produce a reliable supply of good-quality ground water. The spring discharges from a glacial till overlying fractured metamorphic and granitic rocks. Flow from Biledo Spring was nearly constant at about $250 \mathrm{gal} / \mathrm{min}$. The spring flow is a dilute, calcium bicarbonate water recharged primarily from melting snow and ice. The concentration of dissolved ${ }^{222}$ radon in a sample from the spring was $420 \mathrm{pC} / \mathrm{L}-$ just exceeding the U.S. Environmental Protection Agency recommended maximum contaminant level of $300 \mathrm{pC} / \mathrm{L}$ and considerably less than the concentration in ground water in the South Fork Merced River valley. No Giardia was found in a water sample collected in July 1992. Ground-water discharge from other springs and seeps in the Biledo Meadow area exceeds that of Biledo Spring and provides substantial flow for Rainier Creek. Biledo Meadow spring 1 exhibited marked variability in flow and occasionally went dry. Continuous monitoring of the flow of Biledo Spring and sampling for chemical and isotopic analyses would be needed for several years before the long-term variability in flow and quality could be assessed. These data then could be used to determine the relation between precipitation, recharge timing and amounts, residence time of water in the flow system, and the variation of chemical quality in order to evaluate the adequacy of the spring as a long-term source of water supply.

Biledo Spring probably represents the most reliable source of good-quality water for future water-supply needs at Wawona. Ground water also could be obtained from many of the low-yielding wells in the shallow fractured rocks at Wawona. However, ground water in the deeper flow system probably could be used only on a short-term or emergency basis. The South Fork Merced River could be used for additional water supply, but this source of water would be reliable only during winter and spring when streamflows are high.

\section{References Cited}

Bateman, P.C., 1992, Plutonism in the central part of the Sierra Nevada batholith, California: U.S. Geological Survey Professional Paper 1483, $186 \mathrm{p}$.

Bateman, P.C., and Wahrhaftig, Clyde, 1966, Geology of the Sierra Nevada, in Bailey, E.H., ed., Geology of Northern California: California Division of Mines and Geology Bulletin 190, p. 107-172.
Bryan, Kirk, and Taylor, O.G., 1922, Water supply for Mariposa Grove, Yosemite National Park, California: U.S. Geological Survey Open-File Report, $35 \mathrm{p}$.

Buchanan, T.J., and Somers, W.P., 1969, Discharge measurements at gaging stations: U.S. Geological Survey Techniques of Water-Resources Investigations, book 3, chap. A8, 65 p.

Davis, G.H., and Coplen, T.B., 1989, Late Cenozoic paleohydrogeology of the western San Joaquin Valley, California, as related to structural movements in the central Coast Ranges: Geological Society of America Special Paper 234, $40 \mathrm{p}$.

Feth, J.H., Roberson, C.E., and Polzer, W.L., 1964, Sources of mineral constituents in water from granitic rocks, Sierra Nevada, California, and Nevada: U.S. Geological Survey Water-Supply Paper 1535-I, $70 \mathrm{p}$.

Fishman, M.J., and Friedman, L.C., eds., 1989, Methods for determination of inorganic substances in water and fluvial sediments: U.S. Geological Survey Techniques of Water-Resources Investigations, book 5, chap. A1, $545 \mathrm{p}$.

Garrels, R.M., 1967, Genesis of some ground waters from igneous rocks, in Abelson, P.H., ed., Researches in Geochemistry: New York, John Wiley, p. 405-420.

Gat, J.R., and Gonfiantini, R., eds., 1981, Stable isotope hydrology--Deuterium and oxygen-18 in the water cycle: International Atomic Energy Agency Report Series No. 210,335 p.

Goodman, R.E., 1980, Introduction to rock mechanics: New York, John Wiley, 478 p.

Haeni, F.P., 1988, Application of seismic refraction techniques to hydrologic studies: U.S. Geological Survey Techniques of Water-Resources Investigations, book 2, chap. D2, 86 p.

Haimson, B.C., 1978, The hydrofracturing stress measuring method and recent field results: International Journal of Rock Mechanics and Mining Sciences and Geomechanics Abstracts, no. 15, p. 167-178.

Hickman, S.H., Svitek, J., Borchers, J.W., and Scholz, E., 1993, In situ stress measurements at Wawona, Yosemite National Park, California (abs.): Eos, Transactions of the American Geophysical Union, v. 74 , no. 43 , p. 581.

Hickman, S.H., and Zoback, M.D., 1983, The interpretation of hydraulic fracturing pressure-time data for in situ stress determination, in Zoback, M.D., and Haimson, D.C., eds., U.S. National Committee for Rock Mechanics, Hydraulic Fracturing Stress Measurements, Proceedings of a Workshop, December 2-5, 1981: Washington, D.C., National Academy Press, p. 44-54.

Holland, H.D., 1984, The chemical evolution of the atmosphere and ocean: Princeton University Press, $582 \mathrm{p}$. 
Huber, N.K., 1987, The geologic story of Yosemite National Park: U.S. Geological Survey Bulletin $1595,64 \mathrm{p}$.

Huber, N.K., Bateman, P.C., and Wahrhaftig, Clyde, 1989, Geologic map of Yosemite National Park and vicinity, California: U.S. Geological Survey Miscellaneous Investigations Series Map I-1874, scale $1: 125,000,1$ sheet.

Hudson, G.B., Davisson, M.L., and Nimz, G.J., Bõhlke, J.K., and Borchers, J.W., 1993, Isotopic segregation of ground water in the fractured granitic rock at Wawona, Yosemite National Park, California (abs.): Eos, Transaction of the American Geophysical Union, v. 74, no. 43 , p. 582.

International Atomic Energy Agency, 1981, Statistical treatment of environmental isotope data in precipitation: Technical Research Report Series No. 206, $255 \mathrm{p}$.

Jahns, R.H., 1943, Sheet structure in granites: Its origin and use as a measure of glacial erosion in New England: Journal of Geology, v. LI, no. 2, p. 71-98.

Johnson, J.A., Fong-Frydendal, L.J., and Baker, J.B., 1991, Water resources data--California, water year 1991. Volume 5. Ground-water data: U.S. Geological Survey Water-Data Report CA-91-5, 427 p.

Mack, Seymour, and Ferrell, L.M., 1979, Saline water in the foothill suture zone, Sierra Nevada Range, California: Geological Society of America Bulletin, part I, v. 90 , p. 666-675.

Mack, Seymour, and LeTourneau, D., 1982, Saline water in granitic rocks of the western Sierra Nevada foothills: Fresno, California State University, Western Foothills Research Institute Contribution $82-1,34 \mathrm{p}$.

Mack, Seymour, and Schmidt, K.D., 1981, Hydrogeology of the Sierra Nevada foothill lineament near Oakhurst, California: Ground Water, v. 19, no. 2, p. 149-155.

Michel, R.L., 1989, Tritium deposition in the continental United States, 1953-83: U.S. Geological Survey Water-Resources Investigations Report 89-4072, $46 \mathrm{p}$.

Morris, A.W., and Riley, J.P., 1966, The bromide/ chlorinity and sulfate/chlorinity ratios in sea water: Deep-Sea Research, v. 13, p. 699-705.

Mullen, J.R., Anderson S.W., and Hayes, P.D., 1993, Water resources data--California, water year 1993. Volume 3. Southern Central Valley basins and the Great Basin from Walker River to Truckee River: U.S. Geological Survey Water-Data Report CA-93-3, $583 \mathrm{p}$.

Nimz, G.J., Caffee, M.W., and Borchers, J.W., 1993, Extremely low ${ }^{36} \mathrm{Cl} / \mathrm{Cl}$ values in deep ground water at Wawona, Yosemite National Park: Evidence of rapid upwelling of deep crustal waters? (abs.): Eos, Transactions of the American Geophysical Union, v. 74 , no. 42,582 p.
Nordstrom, D.K., Ball, J.W., Donahoe, R.J., and Whittemore, Donald, 1989a, Groundwater chemistry and water-rock interactions at Stripa: Geochimica et Cosmochimica Acta, v. 53, p. 1727-1740.

Nordstrom, D.K., Lindblom, Sten, Donahoe, R.J., and Barton, C.C., 1989b, Fluid inclusions in the Stripa Granite and their possible influence on the groundwater chemistry: Geochimica et Cosmochimica Acta, v. 53, p. 1741-1755.

Paillet, F.L., and Rule, J., 1994, Using borehole geophysics to evaluate the effects of hydraulic stimulation of fractured bedrock aquifers: Society of Professional Well Log Analysts, Annual Logging Symposium, 35th, Tulsa, Okla., June 1994, Transactions, Paper U, pages U1-U11.

Rantz, S.E., 1969, Mean annual precipitation in the California region: U.S. Geological Survey OpenFile Report, scale 1:1,000,000, 2 sheets.

Riggs, J.L., Dupuis, K.W., Nakamura, K., and Spath, D.P., 1983, Detection of Giardia lamblia by immunofluorescence: Applied and Environmental Microbiology, v. 45 , no. 2, p. 698-700.

Roedder, R.E., 1984, Mineralogical Society of America, in Ribbe, Paul, ed., Reviews in Mineralogy: Fluid inclusions, v. $12,664 \mathrm{p}$.

Seeburger, D.A., and Zoback, M.D., 1982, The distribution of natural fractures and joints at depth in crystalline rock: Journal of Geophysical Research, v. 87 , no. B7, p. $5517-5534$.

Scott, J.H., Tibbetts, B.L., and Burdick, R.G., 1972, Computer analysis of seismic refraction data:

U.S. Bureau of Mines Report of Investigation 7595, $95 \mathrm{p}$.

Schmidt, K.D., 1977, Hydrologic monitoring program at Fresno County Waterworks District 41, near Shaver Lake: Fresno, Calif., Final Report, 53 p.

Smith, G.I., Friedman, I., Klieforth, H., and Hardcastle, K., 1979, Areal distribution of deuterium in eastern California precipitation, 1968-1969: Journal of Applied Meteorology, v. 18, no. 2, p. 172-188.

Sorenson, S.K., Riggs, J.L., Dileanis, P.D., and Suk, T.J., 1986, Isolation and detection of Giardia cysts from water using direct immunofluorescence: Water Resources Bulletin, v. 22, no. 5, p. 843-845.

State of California, 1993, Compilation of Federal and State drinking water standards and criteria: Quality Assurance Technical Document 3, 33 p.

Sutley, S.J., Chaffee, M.A., Fey, D.L., and Hill, R.H., 1983, Chemical analyses and statistical summaries for samples of rock, minus- 60 -mesh $(0.25-\mathrm{mm})$ stream sediment, and nonmagnetic heavy-mineral concentrate, Mount Raymond roadless area, Madera County, California: U.S. Geological Survey OpenFile Report 83-646, 22 p.

Swanson, Arvey, 1979, Hard-rock wells get Mariposa through the drought: Pacific Groundwater Digest, January 1979, p. 11-15. 
Thompson, C.G., 1931, Superintendent's monthly report to the Director: National Park Service, July 1931, $43 \mathrm{p}$.

U.S. Environmental Protection Agency, 1991, Radio nuclides in drinking water: U.S. Environmental Protection Agency Fact Sheet 570/9-91-700, 12 p.

U.S. Geological Survey, 1980, National handbook of recommended methods for water data acquisition: U.S. Geological Survey, Office of Water Data Coordination, chap. 2, 150 p.; chap. 3, 130 p.; chap. 5, $194 \mathrm{p}$.
Waber, H.N., and Nordstrom, K.D., 1993, Sources of halogens and sulfate in deep granitic ground waters based on chemical modeling and fluid inclusion leach experiments for Stripa granite: Geological Society of America, 1993 Annual Meeting, Boston, Mass., October 25-28, 1993, Abstracts with Program, p. A-373.

Zoback, M.L., and Zoback, M.D., 1989, Tectonic stress field of the continental United States, in Pakiser, L.C., and Mooney, W.D., eds., Geophysical framework of the continental United States: Geological Society of America Memoir 172, p. 523-539. 
BLANK PAGE 
Appendix A

Geophysical logs of test holes and wells and acoustic televiewer logs of test holes. 
BLANK PAGE 


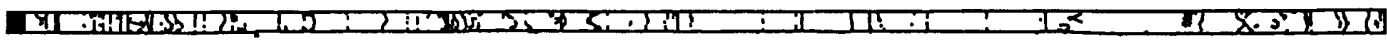
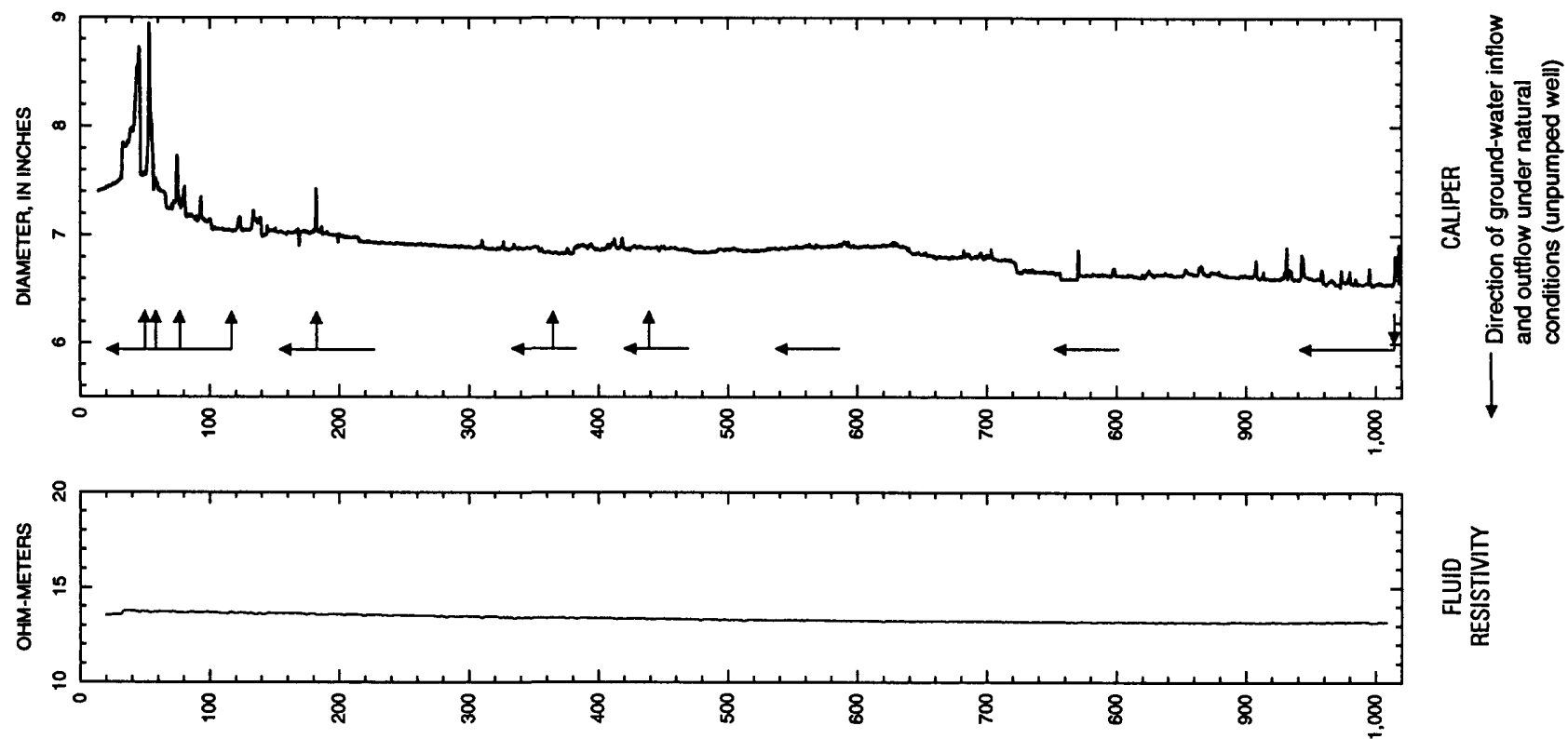

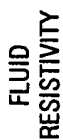

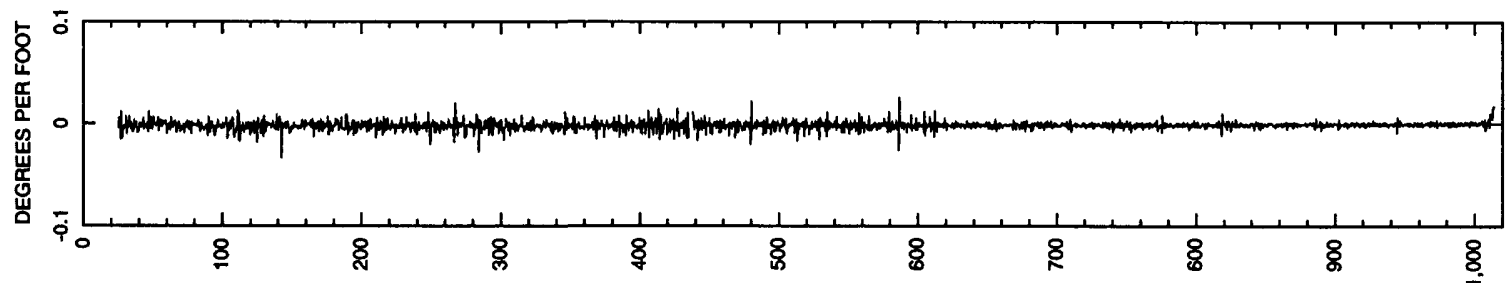

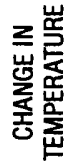

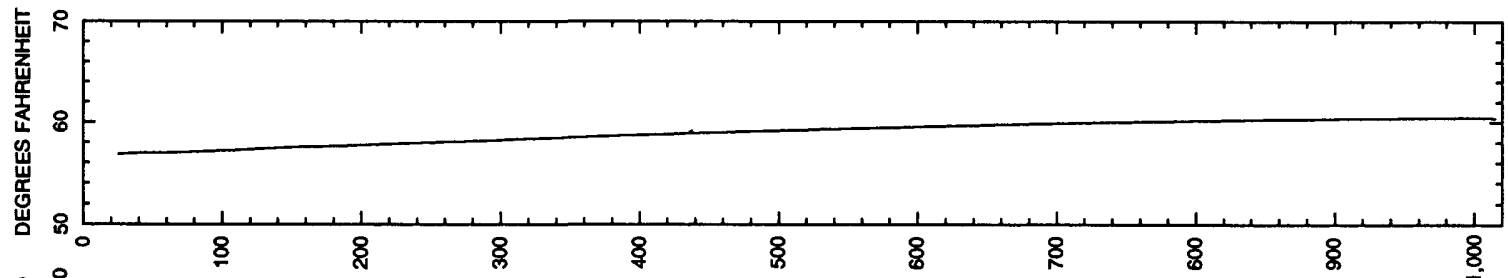

容

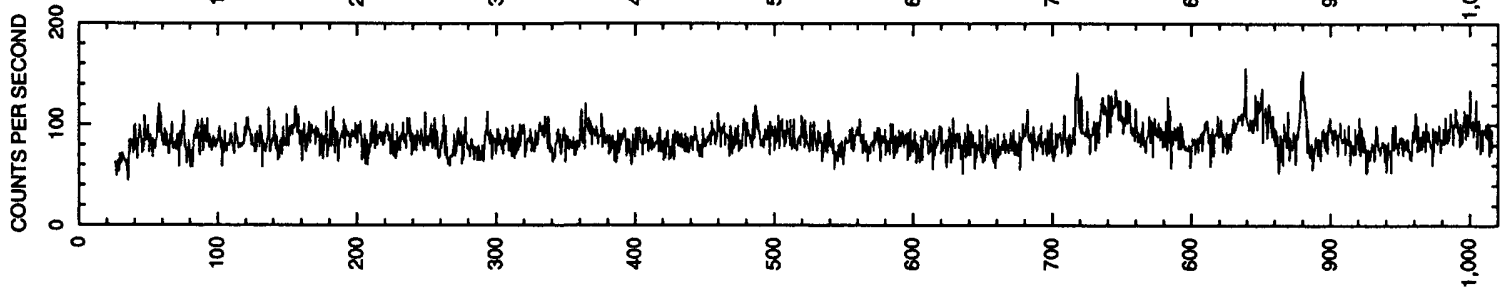

䍃京
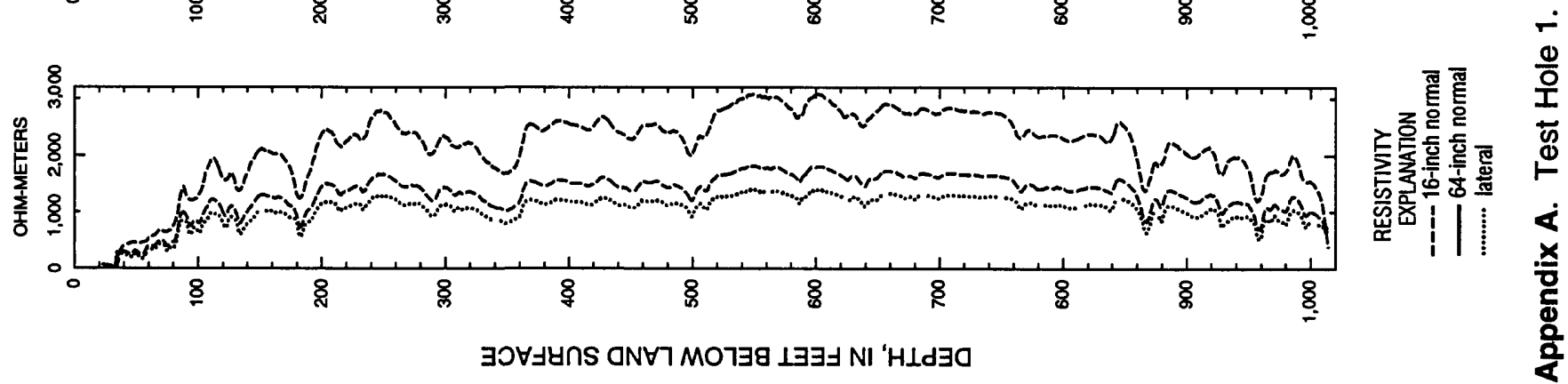


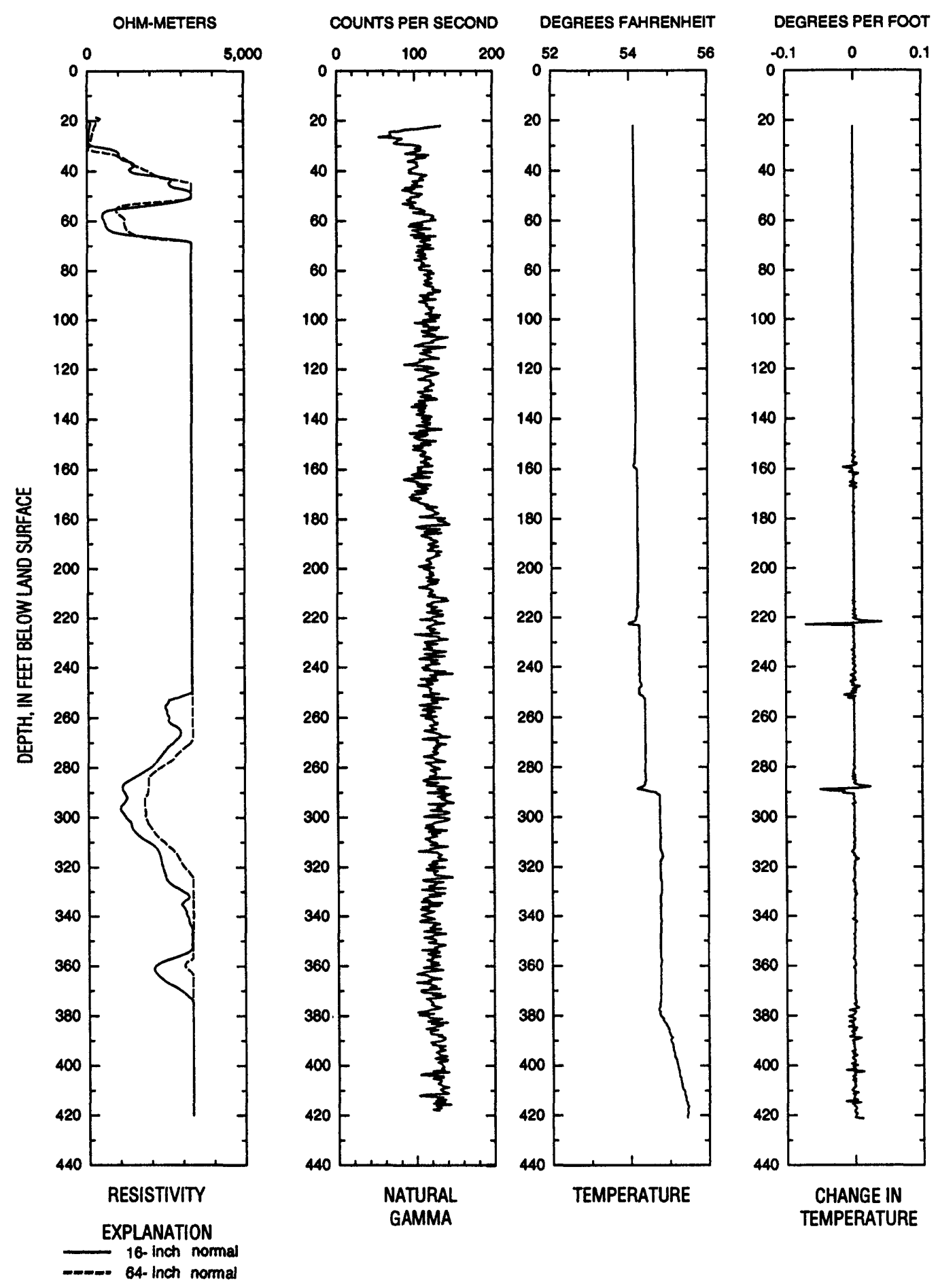

Appendix A. Test Hole 2. 

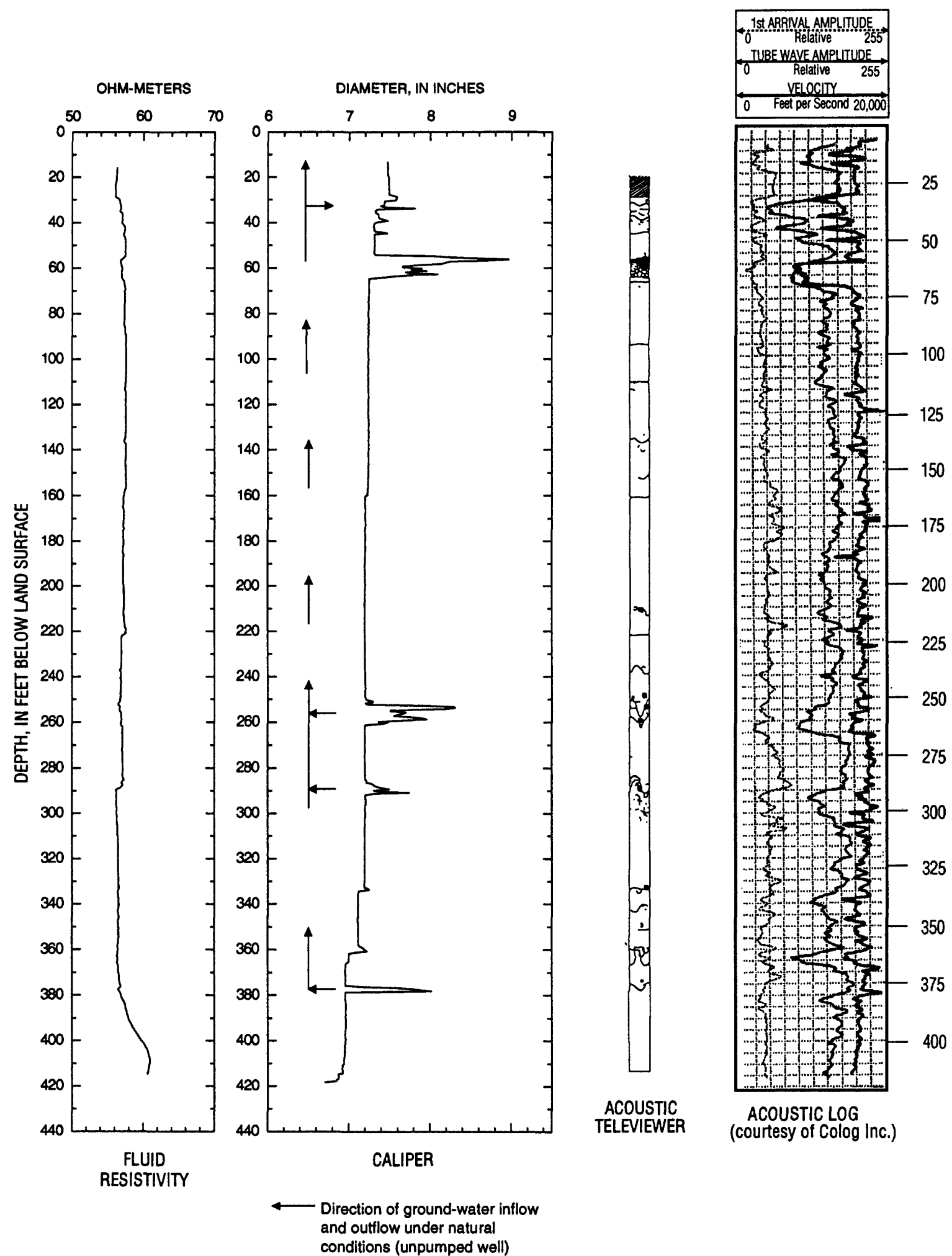

Appendix 1. Test Hole 2--Continued. 

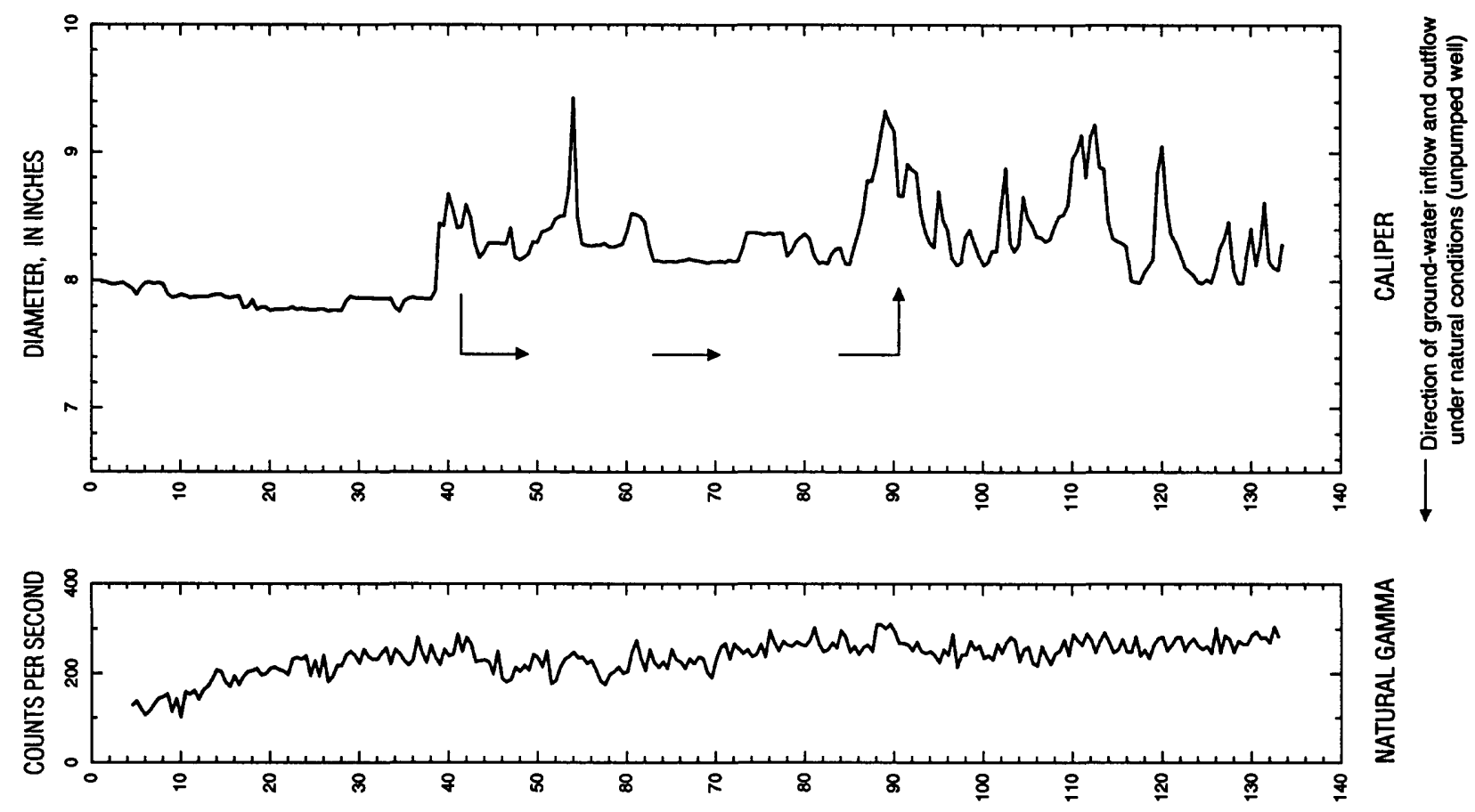

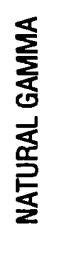
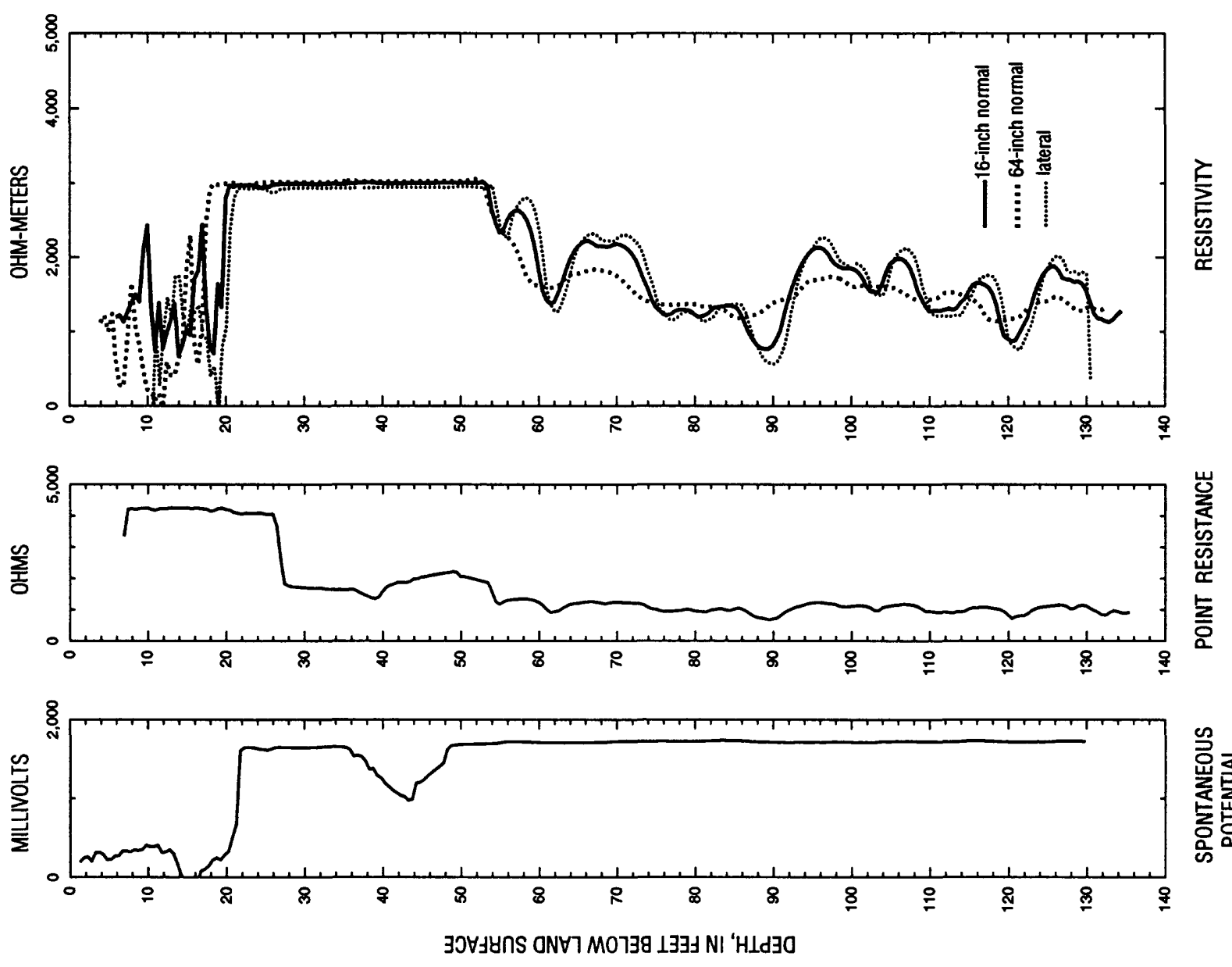

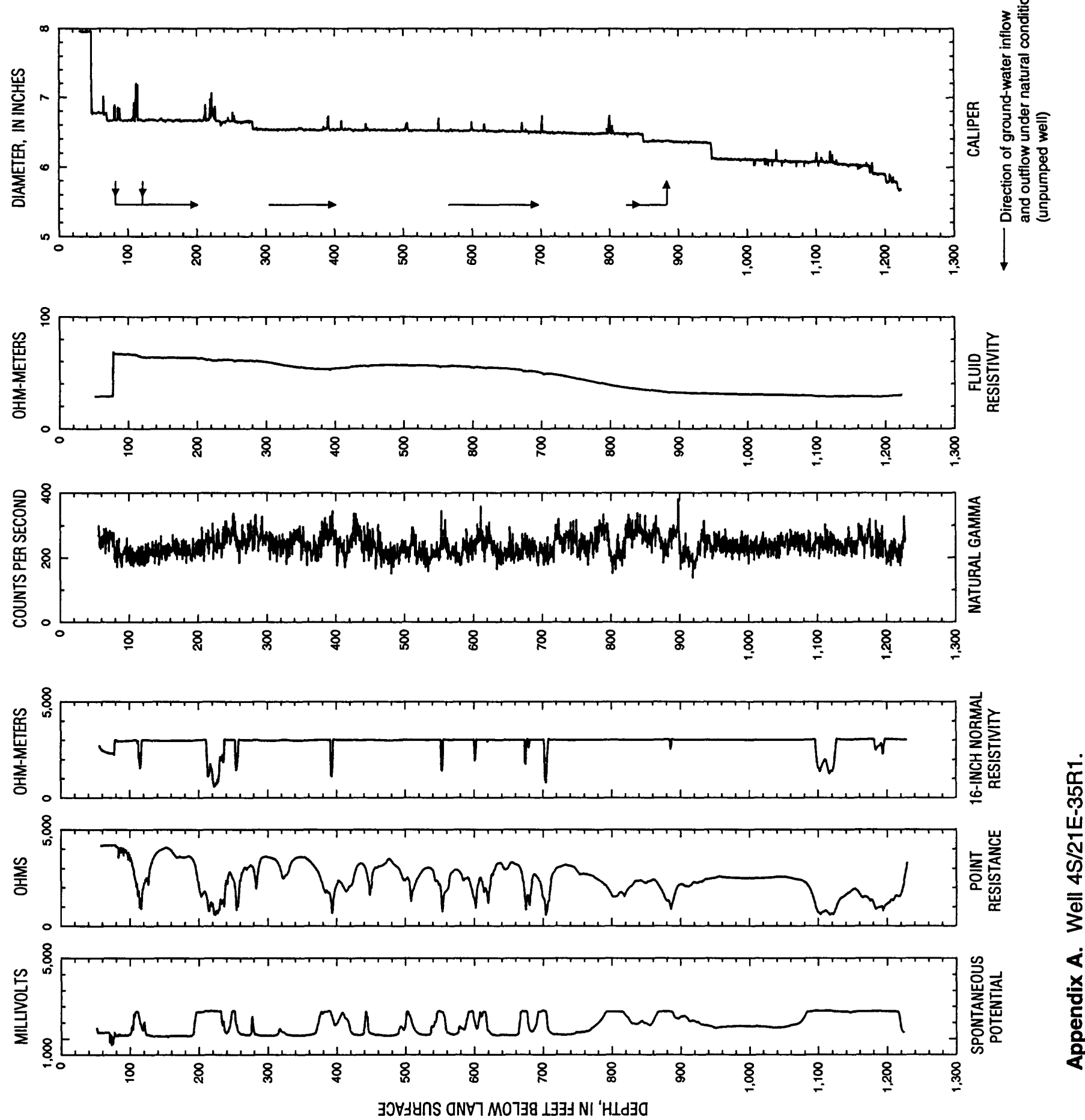

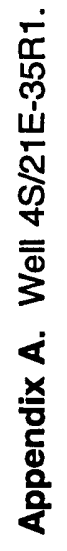



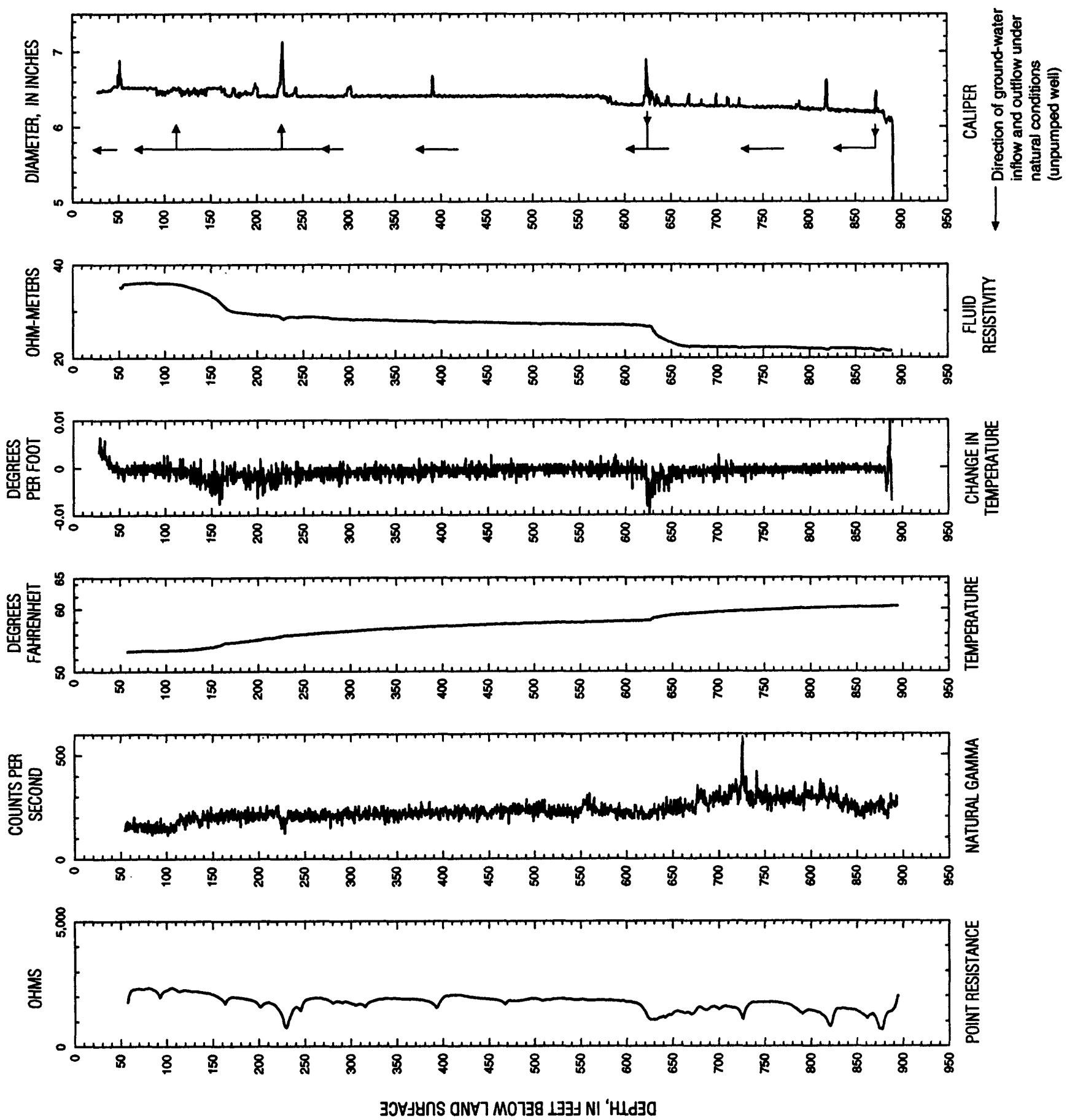


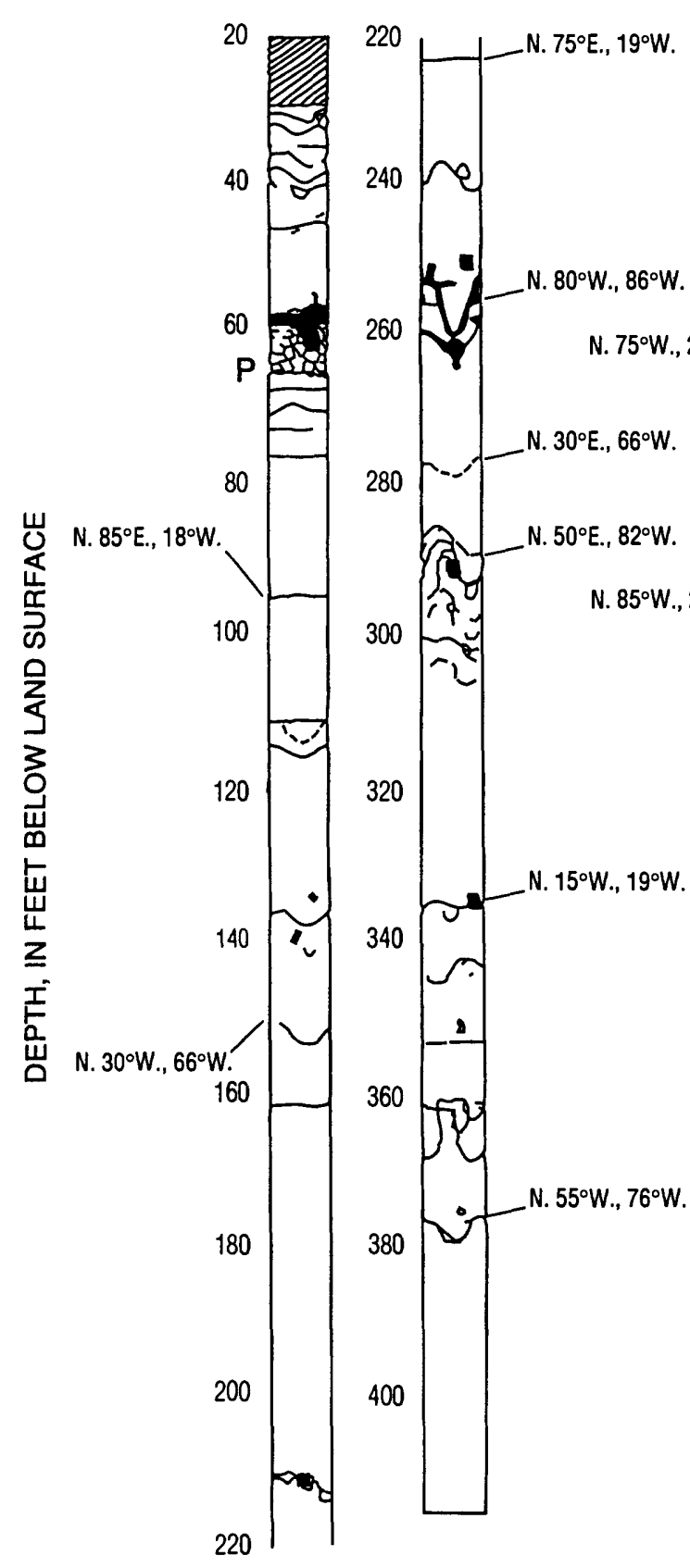

TEST HOLE 2

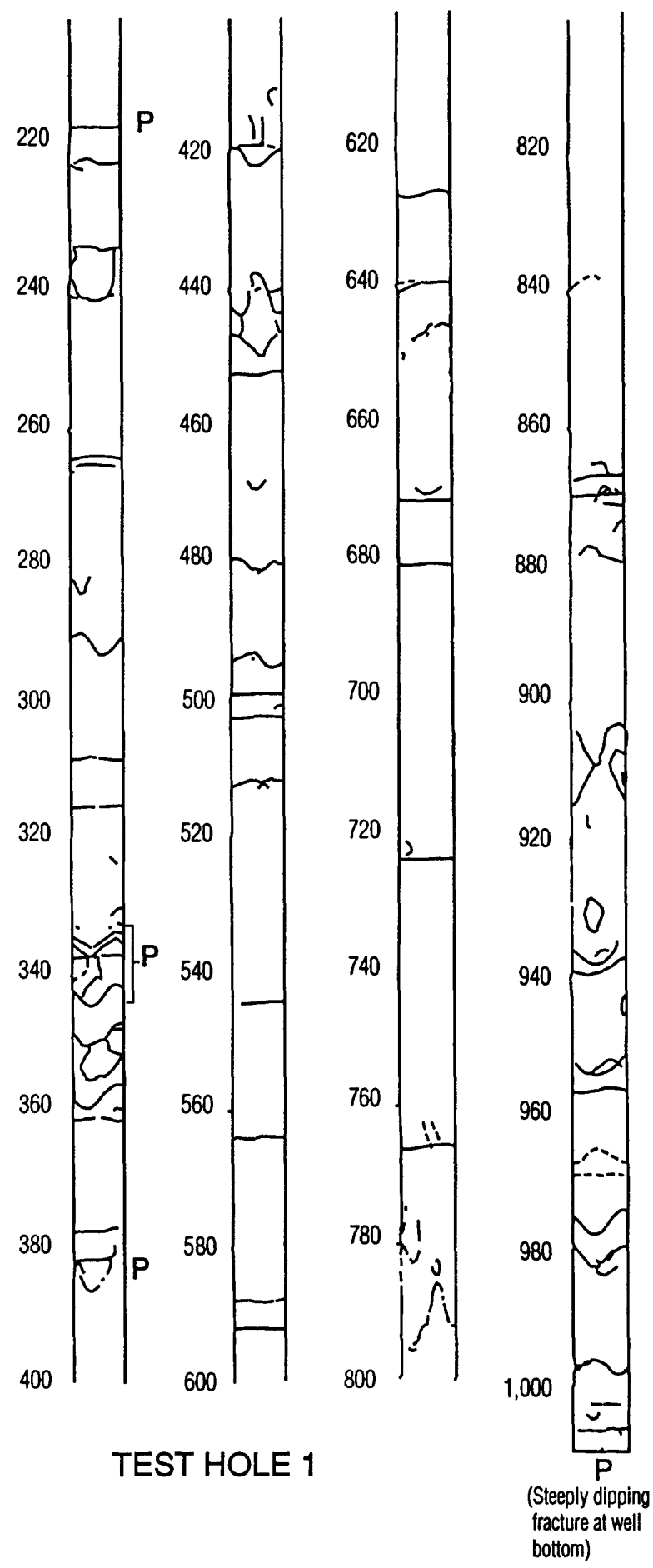

(Sketch courtesy of Fred Paillet, U.S. Geological Survey)

Appendix A. Acoustic televiewer logs of test holes. 
BLANK PAGE 
Appendix B

Hydrographs of water levels in selected observation wells. 

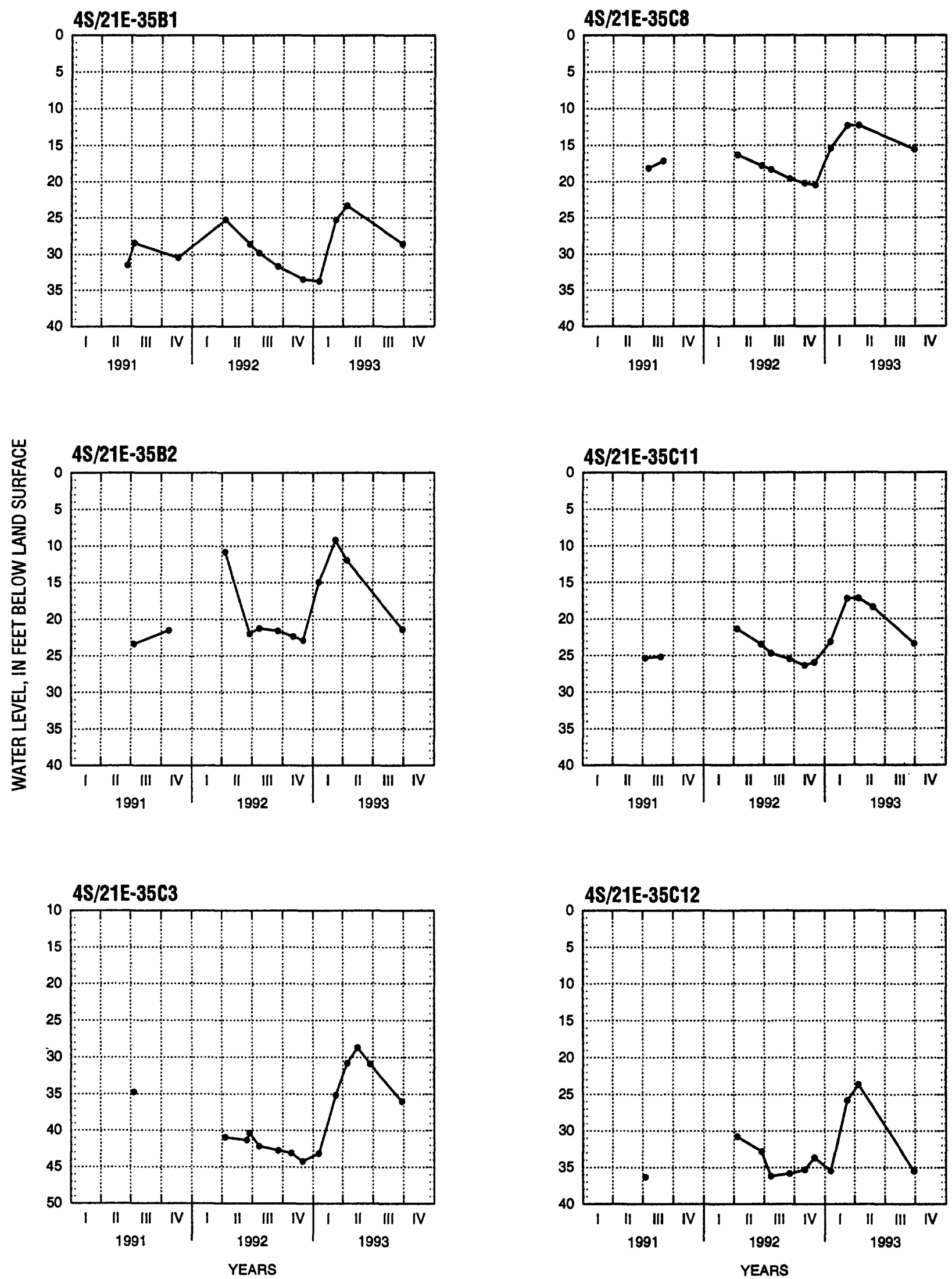

Appendix B. Hydrographs. 

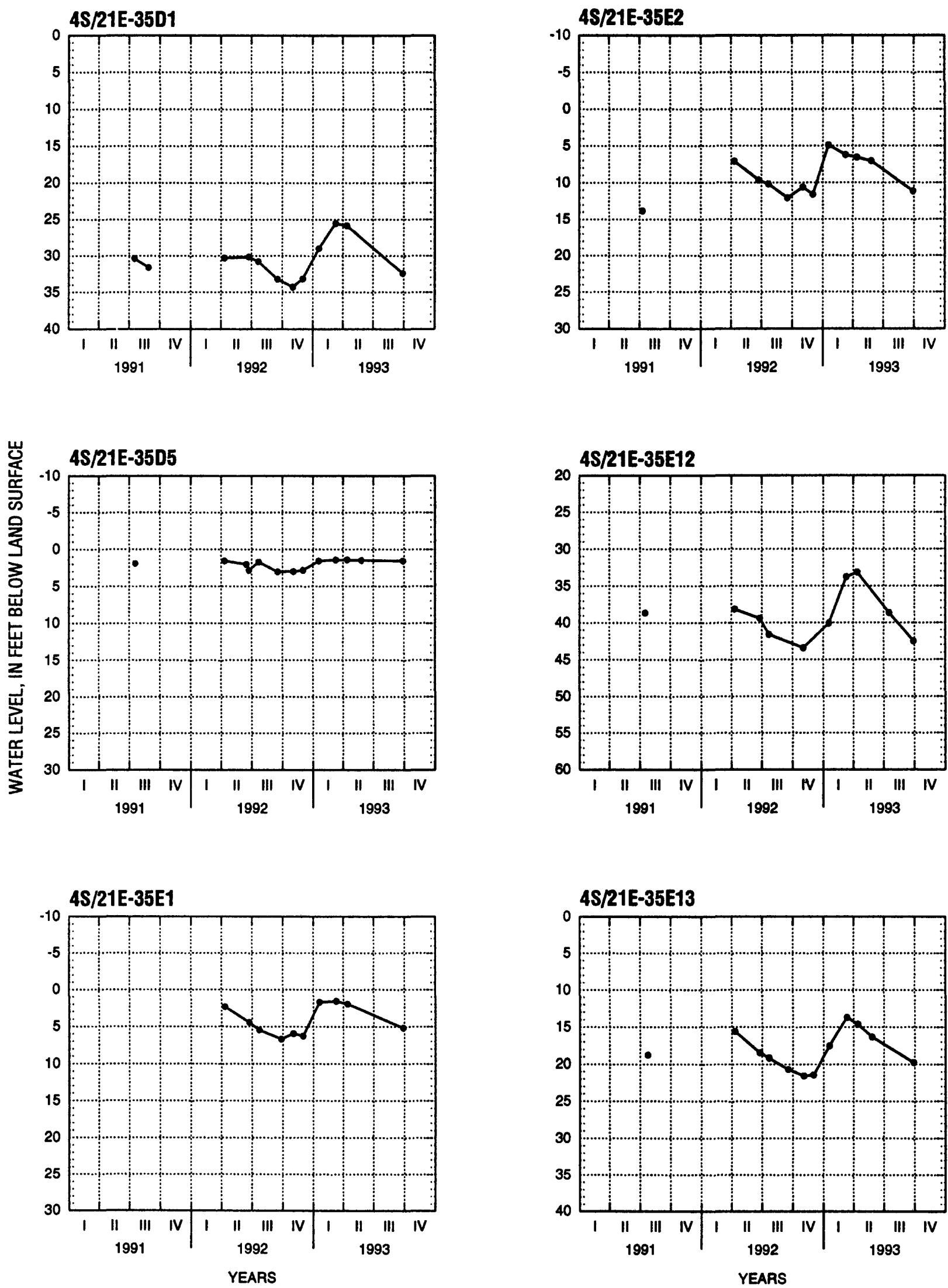

Appendix B. Hydrographs--Continued. 

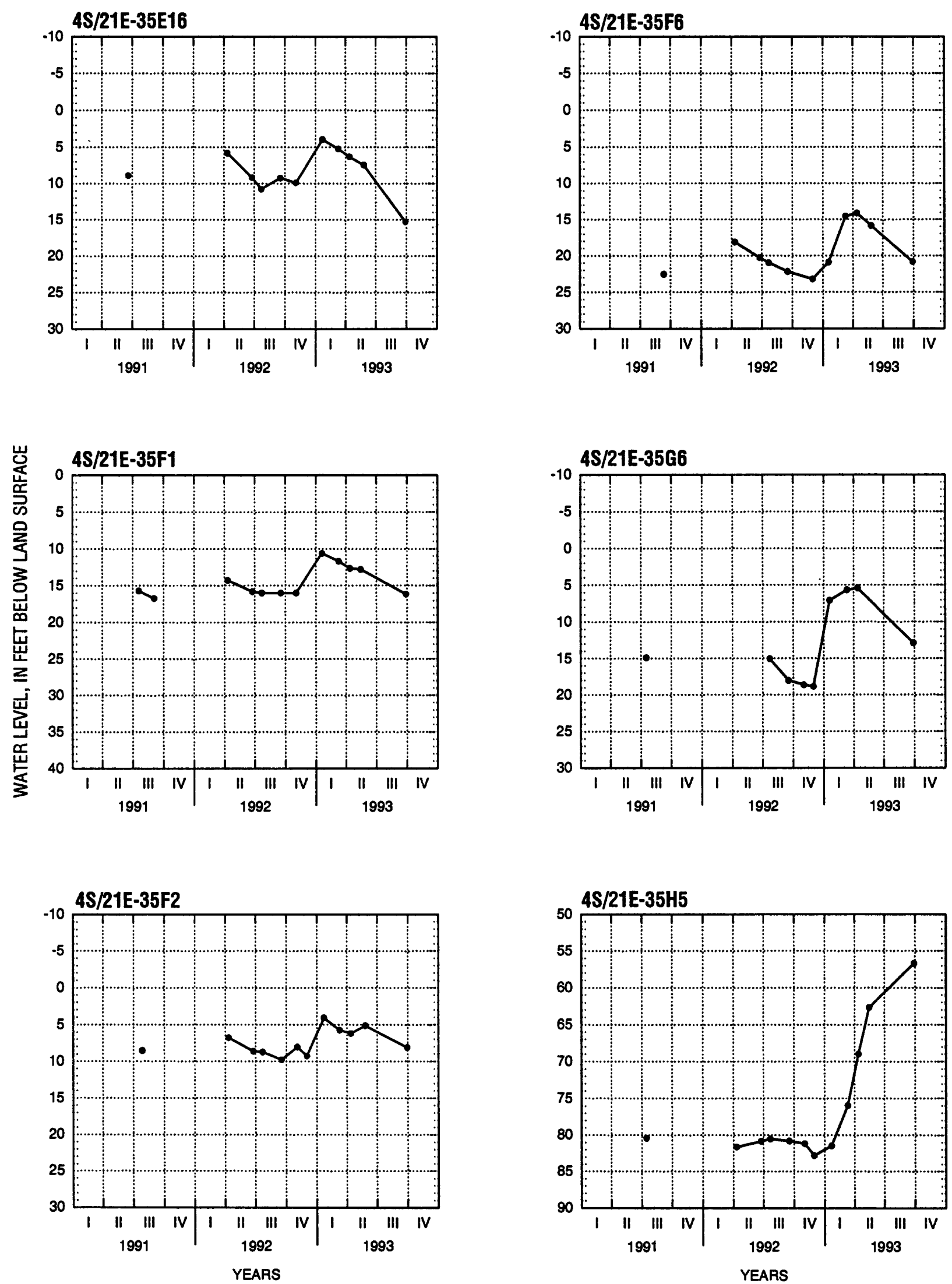

Appendix B. Hydrographs-- Continued. 

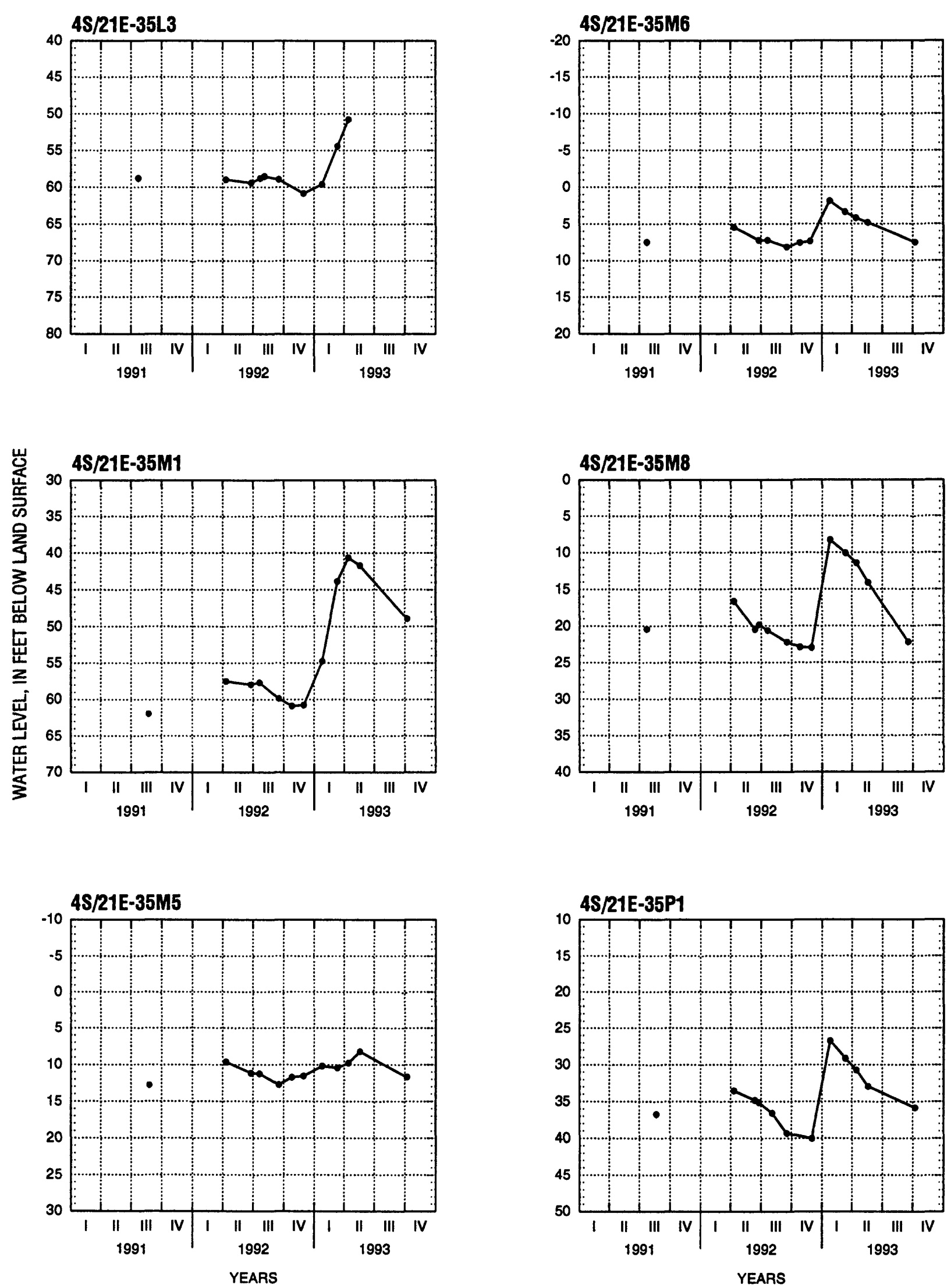

Appendix B. Hydrographs--Continued. 

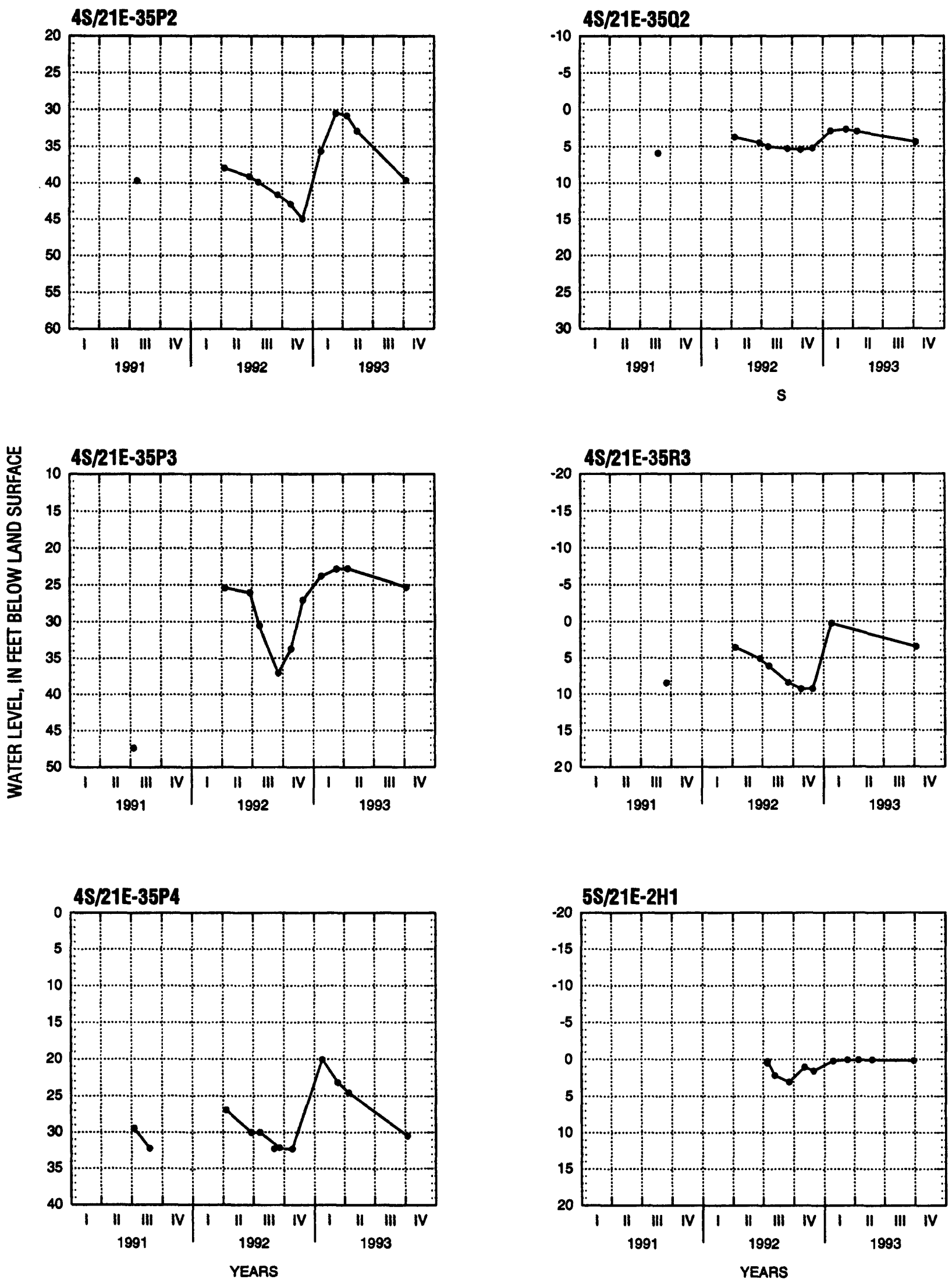

Appendlx B. Hydrographs--Continued. 


\section{Appendix C}

\section{Method used to estimate discharge of Biledo Spring}

Flow of Biledo Spring was estimated by applying a culvert-discharge formula to water depth (head) above the bottom of the 8-in. diameter outflow pipe (pipe invert) in the upper spring cistern. Head above the pipe invert was calculated from the depth to the water surface measured from a reference point on the access manhole in the cistern roof (distance A). The relation between discharge and head above the pipe invert is shown in the discharge table. To use the discharge table, calculate the head above the pipe invert in feet (head = $3.64 \mathrm{ft}-\mathrm{A}$ ) and then find the discharge at the intersection of the appropriate row indicated by tenths of foot of head in the first column and appropriate column indicated by the hundredths of foot of head in the first row of the table. For example, if the head above the pipe invert is $0.47 \mathrm{ft}$, discharge is found at the intersection of the row labeled 0.40 and column labeled 0.07 (discharge is $0.509 \mathrm{ft}^{3} / \mathrm{s}$ ).

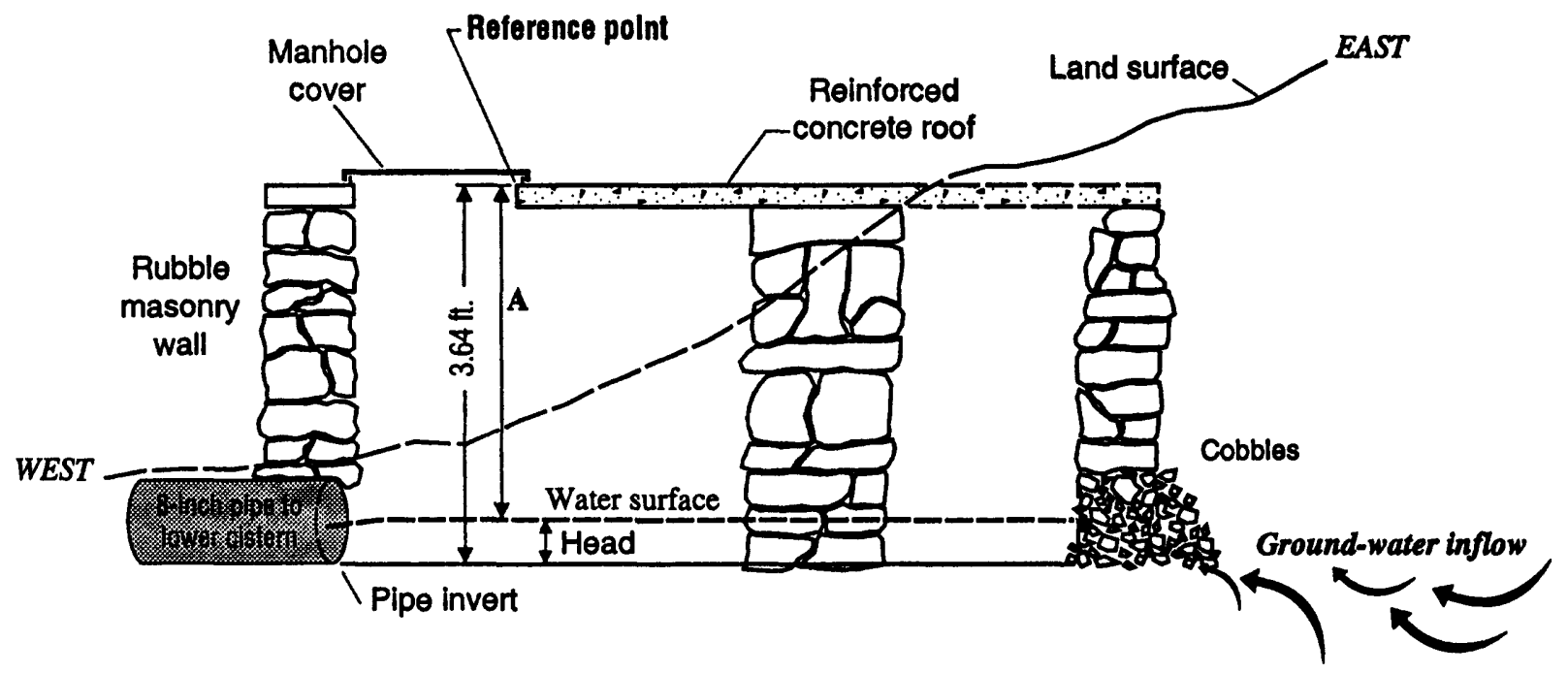

[ft, foot; $\mathrm{ft}^{3} / \mathrm{s}$, cubic feet per second]

\begin{tabular}{ccccccccccc}
\hline $\begin{array}{c}\text { Head above } \\
\text { pipe invert } \\
\text { (ft) }\end{array}$ & \multicolumn{10}{c}{$\begin{array}{c}\text { Discharge } \\
\left(\mathrm{ft}^{3} / \mathrm{s}\right)\end{array}$} \\
\cline { 2 - 11 } & 0.00 & 0.01 & 0.02 & 0.03 & 0.04 & 0.05 & 0.06 & 0.07 & 0.08 & 0.09 \\
\hline 0.00 & .000 & .001 & .003 & .004 & .005 & .007 & .011 & .015 & .019 & .023 \\
.10 & .027 & .033 & .040 & .046 & .053 & .059 & .068 & .077 & .085 & .094 \\
.20 & .103 & .114 & .125 & .136 & .147 & .158 & .171 & .184 & .197 & .210 \\
.30 & .223 & .238 & .253 & .267 & .282 & .297 & .314 & .330 & .347 & .363 \\
.40 & .380 & .398 & .417 & .435 & .454 & .472 & .491 & .509 & .528 & .546 \\
.50 & .565 & .583 & .601 & .620 & .638 & .656 & .674 & .692 & .711 & .729 \\
.60 & .747 & .766 & .785 & .804 & .823 & .842 & .862 & .881 & .900 & .919 \\
.70 & .938 & .956 & .975 & .993 & 1.012 & 1.030 & 1.049 & 1.067 & 1.086 & 1.104 \\
.80 & 1.123 & 1.139 & 1.154 & 1.170 & 1.186 & 1.201 & 1.217 & 1.233 & 1.249 & 1.264 \\
.90 & 1.280 & 1.295 & 1.311 & 1.326 & 1.341 & 1.356 & 1.372 & 1.387 & 1.402 & 1.418 \\
1.00 & 1.433 & & & & & & & & & \\
\hline
\end{tabular}

